\title{
Fruits, seeds, and flowers from the Warman clay pit (middle Eocene Claiborne Group), western Tennessee, USA
}

\author{
Hongshan Wang, Jane Blanchard, and David L. Dilcher
}

\begin{abstract}
In this report, we examine fossil plant reproductive materials from the Warman clay pit in western Tennessee. The investigation of about 600 specimens has resulted in the recognition of 60 species and morphotypes. Based upon comparisons of gross morphology of these specimens with available extant plant materials and the literature, we have been able to assess their affinities with 16 extant families. We are able to relate 36 species and morphotypes to the following families: Altingiaceae, Annonaceae, Araceae, Araliaceae, Bignoniaceae, Euphorbiaceae, Fabaceae, Fagaceae, Hamamelidaceae, Juglandaceae, Lauraceae, Magnoliaceae, Malpighiaceae, Moraceae, Oleaceae, and Theaceae. In addition, 24 morphotypes are not assigned to any family due to the limited number of diagnostic characters. This report represents a comprehensive review on the reproductive materials from a single locality of the Claiborne Group of the southeastern United States. Compared to traditional investigations focused primarily on leaves, this study provides a different perspective for understanding plant diversity for the middle Eocene Claiborne Group.
\end{abstract}

Hongshan Wang. Florida Museum of Natural History, University of Florida, Gainesville, Florida 32611, USA hwang@flmnh.ufl.edu

Jane Blanchard. Florida Museum of Natural History, University of Florida, Gainesville, Florida 32611, USA Ojjhblanchard@aol.com

David L. Dilcher. Departments of Biology and Geology, Indiana University, Bloomington, Indiana 47405, USA dilcher@indiana.edu

KEY WORDS: New genus; new species; new taxa; fruits; seeds; flowers; Claiborne Group; middle Eocene; Tennessee

PE Article Number: 16.3.31A

Copyright: Palaeontological Association December 2013

Submission: 23 May 2013. Acceptance: 30 October 2013

Wang, Hongshan, Blanchard, Jane, and Dilcher, David L. 2013. Fruits, seeds, and flowers from the Warman clay pit (middle Eocene Claiborne Group), western Tennessee, USA, Palaeontologia Electronica Vol. 16, Issue 3; 31A; 73p;

palaeo-electronica.org/content/2013/545-eocene-plants-from-tennessee 


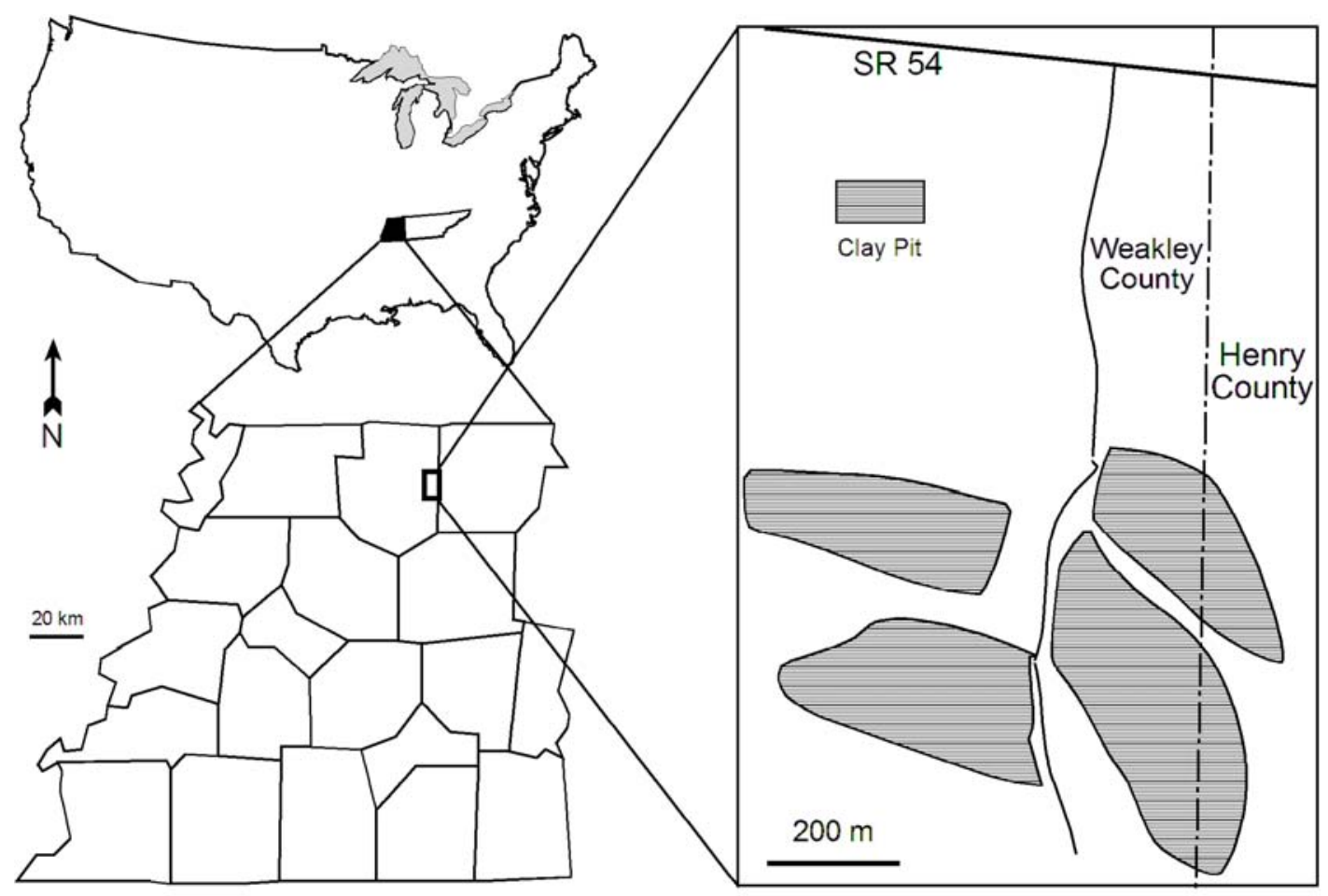

FIGURE 1. Map showing the location of the Warman clay pit, Tennessee, USA.

\section{INTRODUCTION}

The Warman clay pit, one of many middle Eocene plant fossil localities in the Claiborne Group of western Tennessee, is located in the Upper Mississippi Embayment of the southeastern United States (see Dilcher and Lott, 2005, figs. 1 and 2; Figure 1). Abundant well-preserved plant fossils, including leaves, flowers, fruits, seeds, and wood have been collected and studied from these localities for the past 150 years. Since the mid 1800 s, numerous papers have been based upon these fossil plants (Lesquereux, 1859, 1869; Owen, 1860; Safford, 1869; Berry, 1914, 1915, 1916, 1922, 1924, 1926, 1927, 1930, 1937, 1941; Brown, 1939, 1940, 1944, 1946, 1960; Gray, 1960; Dilcher, 1963, 1969, 1971, 2000; Dilcher and McQuade, 1967; Dilcher and Mehrotra, 1969; Dilcher and Dolph, 1970; Tschudy, 1973; Dilcher et al., 1974; Elsik and Dilcher, 1974; Crepet et al., 1974, 1975, 1980; Dolph, 1975; Potter, 1976; Crepet and Dilcher, 1977; Dilcher and Daghlian, 1977; Crepet, 1978; Roth and Dilcher, 1979; Frederiksen, 1980a, 1980b; Crepet and Daghlian, 1980, 1982; Crepet et al., 1980; Jones and Dilcher, 1980; Potter and Dilcher, 1980; Weiss, 1980; Roth, 1981; Zavada and Crepet, 1981; Crepet and Daghlian, 1982; Jones, 1984; Kovach and Dilcher, 1984;
Dilcher and Manchester, 1986, 1988; Jones and Dilcher, 1988; Jones et al., 1988; Taylor, 1987, 1988, 1989; Grote and Dilcher, 1989, 1992; Sun, 1989; Herendeen and Dilcher, 1990a,b,c, 1991; Herendeen et al., 1990; Call and Dilcher, 1992; Herendeen, 1992; Moore, 2001; Moore et al., 2003; Dilcher and Lott, 2005; Danehy et al., 2007; Stull et al., 2011, 2012). These publications focus on leaf megafossils or fossil reproductive materials of a specific taxon (or taxa). In this report, we focus on a comprehensive review of the reproductive materials from a single locality (Warman clay pit) of the Claiborne Group of the southeastern United States.

Berry $(1916,1930,1941)$ considered the plant-bearing clay deposits to be of early Eocene age, belonging to the Wilcox Formation. Palynological data (Elsik, 1974; Elsik and Dilcher, 1974; Frederiksen, 1988) demonstrate that these deposits are best considered to belong to the middle Eocene Cockfield Formation of the Claiborne Group that overlies the Wilcox Group. A stratigraphic chart with historical revisions of the Paleocene and Eocene deposits in western Tennessee can be found in Dilcher and Lott (2005, fig. 4). A simplified stratigraphic column modified from Parks and Carmichael (1990) is presented in Figure 2. 


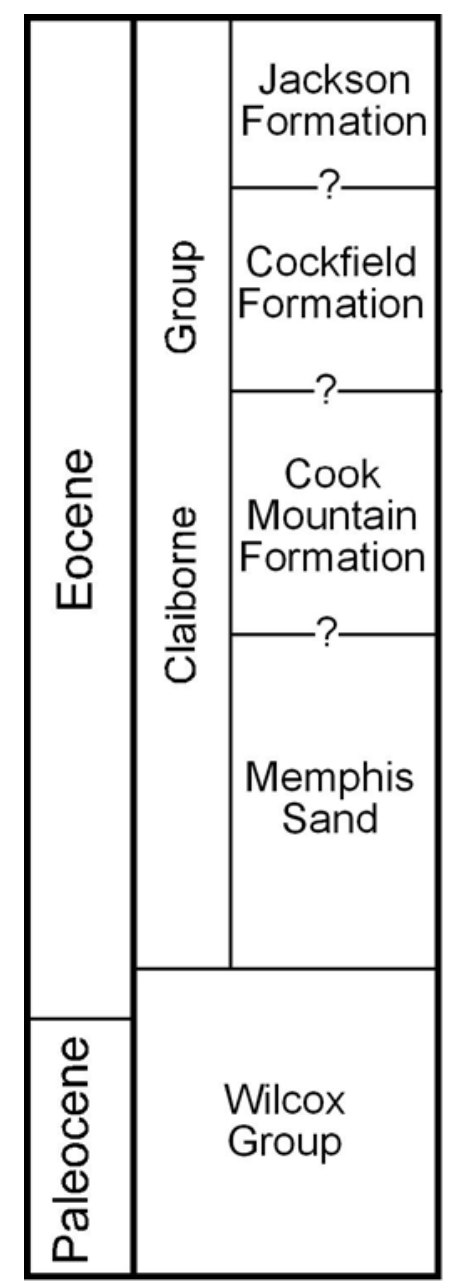

FIGURE 2. Simplified stratigraphic column of the Paleocene Wilcox Group and the Eocene Claiborne Group in the Upper Mississippi Embayment of southeastern United States. "?" indicates that the contact between two formations cannot be reliably defined based upon available information (Parks and Carmichael, 1990).

The Claiborne Group is divided into four units. In ascending order, these four units are the Memphis Sand, Cook Mountain Formation, Cockfield Formation, and the Jackson Formation. The contacts between these units cannot be reliably divided based upon available information (Parks and Carmichael, 1990).

Sedimentary environments of clay lenses like that at Warman clay pit locality have been interpreted as back-swamps on ancient floodplains (Dolph, 1975), abandoned river channels (Dilcher, 1971; Potter, 1976), oxbow lakes (Potter and Dilcher, 1980), or a braided river system on an ancient flood plain (Moore et al., 2003). Potter and Dilcher (1980) examined the sediments from numerous clay pits in western Tennessee and Ken- tucky and presented detailed cross sectional outlines of several clay pits and the lithology of the clay lenses. Based upon the vertical distribution of these clay lenses (localities) in western Tennessee, Potter and Dilcher (1980) suggested that the Warman clay pit locality (or clay lens at this locality) represents the second oldest among all observed clay lenses in western Tennessee, but the precise ages have not been determined due to lack of radiometric control. The clay lenses are more or less " $S$ " shaped and were deposited in the ancient ox-bow lake (Potter, 1976; Potter and Dilcher, 1980).

\section{MATERIALS AND METHODS}

All specimens are compressions or impressions preserved in clay or mudstone collected from the Cockfield Formation of the Claiborne Group at the Warman clay pit locality in Weakley and Henry Counties, Tennessee, USA (Figure 1). The mining operation straddles the county line with most of the excavations in Weakley County, and just one small area extending into Henry County, Tennessee. The Warman clay pit was opened by the Spinks Clay Company in about 1959. Collections were made from the pits exposed as the clay deposit continued to be mined until about 1990 .

Specimens are cataloged using the locality prefix UF15826- (Warman clay pit locality), followed by a catalog number (e.g., UF15826-34381). All figured and cited specimens are housed in the Paleobotany and Palynology Type Collection at the Florida Museum of Natural History, Gainesville, Florida.

Descriptions of specimens are based upon direct observations under a dissecting microscope. All specimens were photographed using a Nikon D100 digital camera and only color balance, sharpness, brightness, and/or contrast of the images were adjusted using Adobe Photoshop CS software. Comparisons with other fossil taxa are based upon published figures or specimens stored at the Paleobotany Type and Figured Collection at the Florida Museum of Natural History, Gainesville, Florida, USA, except some fossils published by Berry (1930) which were based upon images of type specimens taken by Steven R. Manchester at the Paleobiology Department, the National Museum of Natural History, Smithsonian Institution, Washington D.C., USA. Comparisons with extant taxa are also based upon published illustrations and/or specimens of the Modern Leaf and Fruit/Seed Collections stored at the Paleobotany Collection, Florida Museum of Natural History. 
Specimens that have previously been published and have enough characters to assess their modern affinities are assigned to extant families. In the text, these families are arranged according to APG III (2009). New taxa, combinations, and morphotypes have been established. Other specimens whose modern affinities are unknown are classified into morphotypes and informal names are used. Their arrangement in the text is by their organ types in the following order: inflorescences (flowers), infructescences, fruits, seeds, and other unknown structures. Following the description of each taxon/morphotype, the total number of specimens examined and catalog numbers for the illustrated specimens are listed. For some morphotypes, only brief descriptions are provided due to the small number of specimens and limited characters available for examination. They are presented here with the hope of supplementing them from future collections.

Table 1 lists all taxa/morphotypes reported from the Warman clay pit locality, Tennessee.

\section{SYSTEMATICS}

Order LAURALES Perleb, 1826

Family LAURACEAE de Jussieu, 1789

Genus LAUROFLORUM gen. nov.

Diagnosis. Flowers small, 3-merous and hypogynous; six perianth parts radiating from a central hypanthium. Each perianth segment having one strong central and two lateral veins; central vein extending to the apex of the perianth segment while the lateral veins extending $1 / 2$ to $2 / 3$ of the perianth length. Pedicel ca $5 \mathrm{~mm}$ long and $0.5 \mathrm{~mm}$ wide. Small, round, brown resin glands present on all floral parts and more abundant around the hypanthium.

Etymology. "Lauro-" refers to their affinity with Lauraceae and "flor-"from Latin refers to flower.

Discussion. Berry (1916) described two species, i.e., Laurophyllum preflorum (p. 313, pl. 86, fig. 5) and Laurophyllum florum (p. 313, pl. 86, fig. 6) from the La Grange Formation in Fayette County, Tennessee. He assigned both species to Laurophyllum, a fossil-genus for Lauraceous leaves. The assignment of these two species to the genus is inappropriate. We assign these flowers with probable lauraceous affinities to a new genus. The single specimen of Laurophyllum florum is poorly preserved, and the single specimen for Laurophyllum preflorum seems to be a floral bud. Their poor preservation makes it difficult to compare them with the current specimens. A few years later, Berry (1922) described three calyxes and three fruits from the Goss pit, a locality about half a mile east of Mansfield, De Soto Parish, Louisiana, and assigned them to Laurus verus. The assignment of these specimens is questionable because the affinity of these specimens to Laurus is based upon limited morphological characters. We propose a new fossil-genus, Lauroflorum, to accommodate these possible lauraceous flowers.

Type species. Lauroflorum warmanensis sp. nov., designated here.

\section{Lauroflorum warmanensis sp. nov.}

(Figure 3)

Diagnosis. Same as for the genus.

Description. Flowers small, 3-merous and hypogynous. Vertically preserved flowers showing six perianth parts of equal size radiating from a central depression (or a hypanthium) ca $1 \mathrm{~mm}$ in diameter and ca $1 \mathrm{~mm}$ in length. Perianth segments ca 2 $\mathrm{mm}$ long and $1 \mathrm{~mm}$ wide with sub-acute apices. Each having one strong central and two lateral veins. Central vein extending to the apex of the perianth segment while the lateral veins extending $1 / 2$ or $2 / 3$ of the perianth length. Laterally preserved flowers with six perianth parts of different sizes connecting to a tubular structure ca $1 \mathrm{~mm}$ in diameter at its apex and tapering to ca $0.5 \mathrm{~mm}$ at the peduncular (pedicel) end. Pedicel ca $5 \mathrm{~mm}$ long and $0.5 \mathrm{~mm}$ wide at its end. Small, round (ca $0.03 \mathrm{~mm}$ in diameter) brown resin glands occur on all floral parts but are more abundant around the hypanthium.

Species epithet. Referring to the occurrence of the flowers at the Warman clay pit, Tennessee.

Number of specimens examined. 6 .

Holotype. Designated here. UF15826-51527 (Figure 3.1).

Paratypes. UF15826-2237 (Figure 3.4); 33556 (Figure 3.8); 33558 (Figure 3.2, 3.3); 49563 (Figure 3.6, 3.7); 51953 (Figure 3.5).

Discussion. These specimens appear to be tubular flowers. The variation of size of the perianth parts for laterally preserved flowers is probably caused by preservation. The glands or spherical resin droplets are variable in number but uniform in size and shape and are most abundant on the hypanthium. Crepet (1979, p. 229, pl. VII, fig. 3) described the same flower from the Warman clay pit (Figure 3.4) as one of a group of flowers demonstrating the syndrome of "small fly blossoms." $\mathrm{He}$ proposed that this group of flowers represents a variety of families or genera and they are pollinated by a variety of anthophilous insects.

Lauraceous leaves (Dilcher, 1963) are common from the middle Eocene Claiborne Group. Oil 
TABLE 1. A list of taxa and morphotypes recognized from Warman clay pit and their proposed modern affinities.

\begin{tabular}{|c|c|c|}
\hline $\begin{array}{c}\text { Proposed Modern } \\
\text { Affinity }\end{array}$ & Taxon/Morphotype & Figure number \\
\hline Lauraceae & Lauroflorum warmanensis gen. et sp. nov. & Figure 3 \\
\hline \multirow[t]{2}{*}{ Annonaceae } & Anonaspermum robertsi (Berry) comb. nov. & Figure $4.1-3,4.5-8$ \\
\hline & Anonaspermum warmanensis sp. nov. & Figure 4.4 \\
\hline Magnoliaceae & cf. Magnolia sp. & Figure 5 \\
\hline Araceae & cf. Acorites heeri Crepet & Figure 6 \\
\hline Altingiaceae & Altingiaceae Infructescence & Figure 7 \\
\hline \multirow[t]{2}{*}{ Hamamelidaceae } & Corylopsis grotei sp. nov. & Figure 8 \\
\hline & Hamamelis sp. & Figure 9 \\
\hline \multirow[t]{12}{*}{ Fabaceae } & Eomimosoidea plumosa Crepet and Dilcher 1977 & Figures 10,11 \\
\hline & Protomimosoidea buchananensis Crepet and Taylor 1986 & Figure 12 \\
\hline & Caesalpinia claibornensis Herendeen and Dilcher 1991 & Figure 13.4-5 \\
\hline & Crudia grahamiana Herendeen and Dilcher 1990c & Figure 13.6 \\
\hline & Diplotropis claibornensis Herendeen and Dilcher 1990b & Figure 14.1 \\
\hline & Eliasofructus claibornensis Herendeen and Dilcher 1990a & Figure 14.2 \\
\hline & cf. Erythrophleum sp. & Figure 13.2 \\
\hline & cf. Gleditsia? mississippiensis (Berry) Berry & Figure 14.3 \\
\hline & cf. Leguminosites phyllocarpoides Berry 1930 & Figure 13.3 \\
\hline & Ormosia sp. & Figure $14.5,14.6$ \\
\hline & Swartzia sp. & Figure 13.1 \\
\hline & "Thick walled fruit" & Figure 14.4 \\
\hline \multirow[t]{4}{*}{ Fagaceae } & Quercus oligocenensis Daghlian and Crepet 1983 & Figure 15 \\
\hline & Fagaceous Fruit Type 1 & Figure 16.1-2 \\
\hline & Fagaceous Fruit Type 2 & Figure 16.3 \\
\hline & Fagaceous Fruit Type 3 & Figure 17 \\
\hline \multirow[t]{2}{*}{ Juglandaceae } & Eokachyra aeolius Crepet, Dilcher and Potter 1975 & Figure 18 \\
\hline & Paleooreomunnea stoneana Dilcher, Potter and Crepet 197 & Figure 19 \\
\hline Euphorbiaceae & Hippomaneoidea warmanensis Crepet and Daghlian & Figure 20 \\
\hline Malpighiaceae & Eoglandulosa warmanensis Taylor and Crepet 1987 & Figure 21 \\
\hline Moraceae & Cornerocarpon copiosum gen. et sp. nov. Grote & Figures 22, 23 \\
\hline \multirow[t]{4}{*}{ Theaceae } & Gordonia warmanensis Grote and Dilcher 1992 & Figure 24 \\
\hline & cf. Gordonia sp. 1 & Figure 25 \\
\hline & cf. Gordonia sp. 2 & Figure 26 \\
\hline & Andrewsiocarpon henryense Grote and Dilcher 1989 & Figure 27 \\
\hline Bignoniaceae & Grotea warmanensis gen. et sp. nov. & Figure 28.1 \\
\hline Oleaceae & Fraxinus wilcoxiana (Berry) Call and Dilcher 1992 & Figure 29 \\
\hline Araliaceae & "Aralia" semina Berry & Figure 30 \\
\hline
\end{tabular}


WANG, BLANCHARD, \& DILCHER: EOCENE PLANTS FROM TENNESSEE

TABLE 1 (continued).

\begin{tabular}{|c|c|c|}
\hline $\begin{array}{l}\text { Proposed Modern } \\
\text { Affinity }\end{array}$ & Taxon/Morphotype & Figure number \\
\hline \multirow{24}{*}{$\begin{array}{l}\text { Angiospermae } \\
\text { incertae sedis }\end{array}$} & Infructescence Type 1 & Figure 31 \\
\hline & Infructescence Type 2 & Figure 32 \\
\hline & Infructescence Type 3 & Figure 33 \\
\hline & Antholithes wilcoxensis Berry 1930 & Figure 34 \\
\hline & Solanites pusillus Berry 1930 & Figure 35 \\
\hline & Floral Morphotype 1 & Figure $36.1-2$ \\
\hline & Floral Morphotype 2 & Figure $36.3-4$ \\
\hline & Floral Morphotype 3 & Figure 37 \\
\hline & Floral Morphotype 4 & Figure 38 \\
\hline & Floral Morphotype 5 & Figure 39 \\
\hline & Floral Morphotype 6 & Figure 40 \\
\hline & Carpolithus collinsi (Berry) comb. nov. & Figure 41 \\
\hline & Carpolithus complanata (Lesquereux) comb. nov. & Figure 42 \\
\hline & Carpolithus prangosoides Berry 1916 & Figure 43 \\
\hline & Carpolithus sophorites Berry 1916 & Figure 44 \\
\hline & Carpolithus warmanensis sp. nov. & Figure 45 \\
\hline & "Copaifera" yeguana Berry 1915 & Figure 46 \\
\hline & Palmocarpon wilcoxiana (Berry) comb. nov. & Figures 47,48 \\
\hline & "Sparganium" sp. & Figure 49 \\
\hline & Fruit/Seed Type 1 & Figure 50 \\
\hline & Fruit/Seed Type 2 & Figure 51 \\
\hline & Fruit/Seed Type 3 & Figure 52 \\
\hline & Fruit/Seed Type 4 & Figure 53 \\
\hline & Fruit/Seed Type 5 & Figure 54 \\
\hline Plant incertae sedis & Equisetum? sp. & Figure 55 \\
\hline
\end{tabular}

glands are frequently observed on these lauraceous leaves. We relate these flowers to Lauraceae based upon the following characters: 1) the flowers are small, 3-merous, and hypogynous; 2) the presence of resin glands on the flowers; and 3) the co-occurrence of these flowers with lauraceous leaves from the same locality.

Order MAGNOLIALES Bromhead, 1838

Family ANNONACEAE de Jussieu, 1789

Genus ANONASPERMUM Ball, 1931

Type species. Anonaspermum robertsi (Berry) comb. nov.

Anonaspermum robertsi comb. nov.

(Figure 4.1-3, 4.5-8)

1930 "Anona" robertsi Berry, p.70-71, pl.41, figs. 14-18.
Description. Laterally (longitudinally) compressed seed reniform, 1-2.3 cm long and 0.9-1.4 cm wide. Vertically compressed seed orbicular, ca $0.9 \mathrm{~cm}$ in diameter. Transverse endosperm ruminations present. Seed testa $0.2 \mathrm{~mm}$ to $1.5 \mathrm{~mm}$ thick.

Number of specimens examined. 15.

Lectotype. Berry (1930), pl. 41, fig. 18, p. 70-71 (USNM accession number 146767).

Additional specimens. UF15826-51365 (Figure 4.1); 30837 (Figure 4.2); 51289 (Figure 4.7), 53986 (Figure 4.6); 51297 (Figure 4.8); 51266 (Figure 4.3, 4.5).

Discussion. The fossil-genus, Anonaspermun, was established by Ball (1931, p. 121) "for those fossil seeds, or parts of seeds, which bear a marked resemblance in the external structure of the endosperm to the corresponding parts in the 


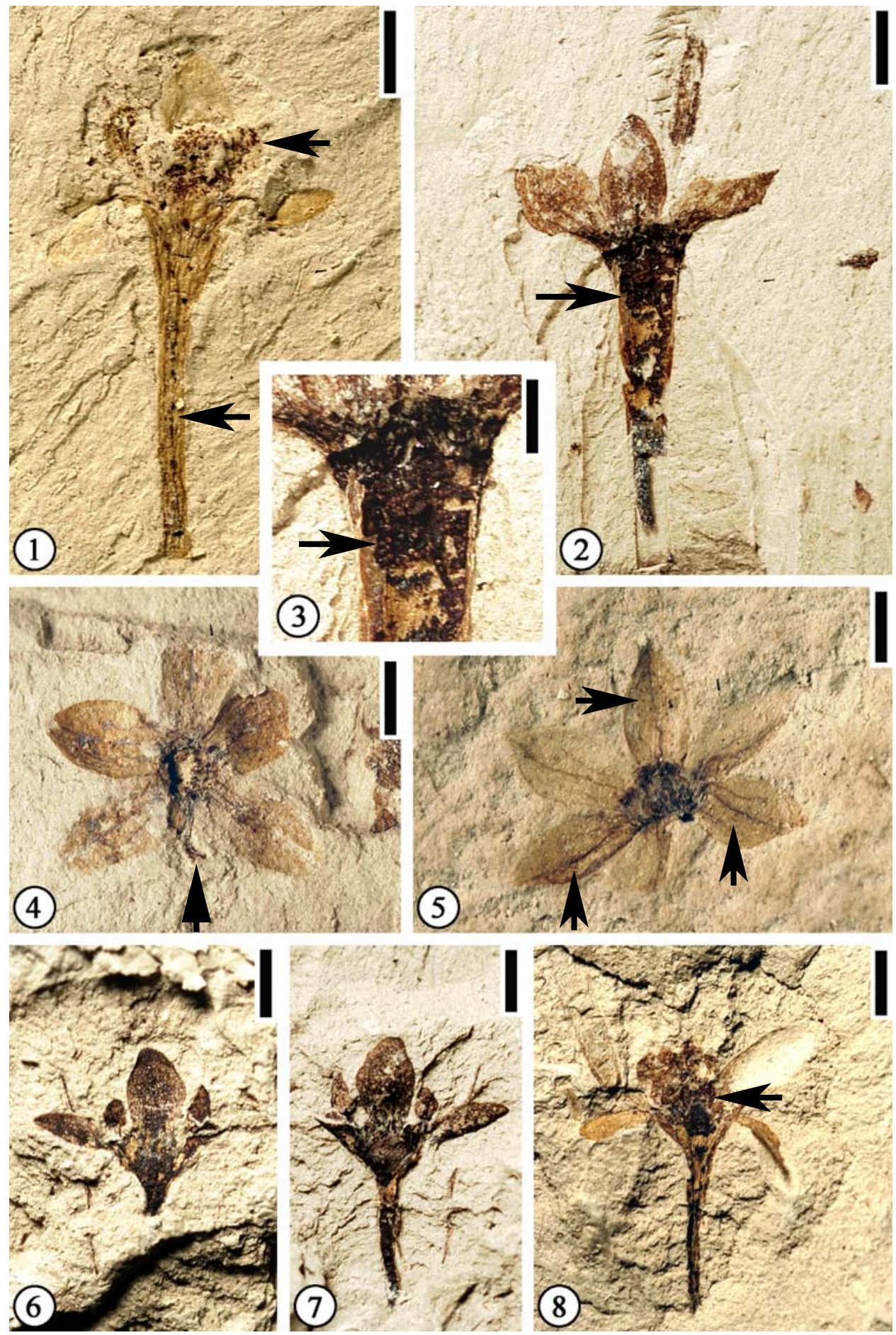

FIGURE 3. Lauroflorum warmanensis gen. et sp. nov. All scale bars equal $1 \mathrm{~mm}$ except for the bar in Figure 3.3, which equals $0.5 \mathrm{~mm}$. 1. UF15826-51527. Laterally preserved flower. Note long pedicel (indicated by lower arrow) and glands (indicated by upper arrow). 2. UF15826-33558. Laterally preserved flower showing three perianth parts and clustered glands (indicated by arrow). 3. Enlargement of Figure 3.2 showing clustered glands (indicated by arrow). 4. UF15826-2237. Vertically preserved flower showing six perianth parts (arrow at the bottom inciates the sixth perianth part). 5. UF15826-51953. Vertically preserved flower showing six perianth parts. Note one mid-vein and two parallel thinner veins in each part, and scattered glands on the perianth parts (indicated by arrows). 6. UF15826-49563. Laterally preserved flower showing perianth parts. 7. Counterpart of Figure 3.6 showing a long pedicel. 8. UF15826-33556. Laterally preserved flower showing long pedicel, perianth parts and clustered glands (indicated by arrow). 

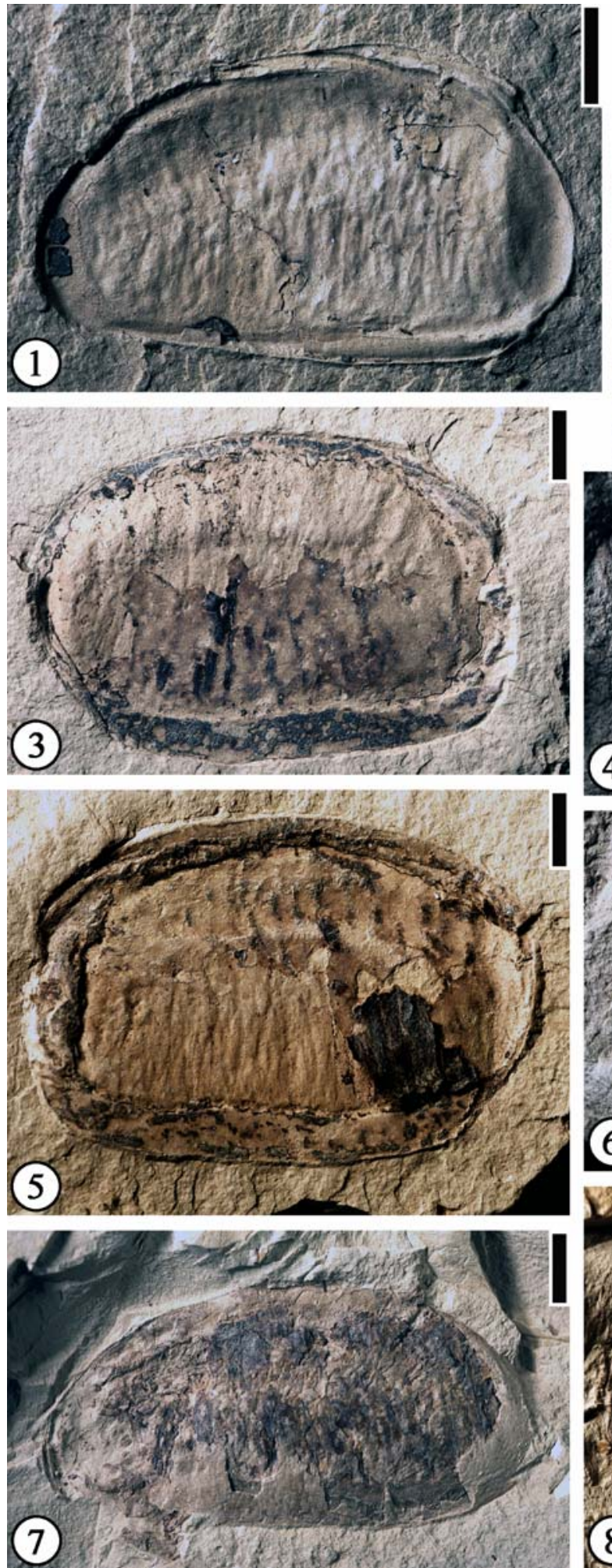
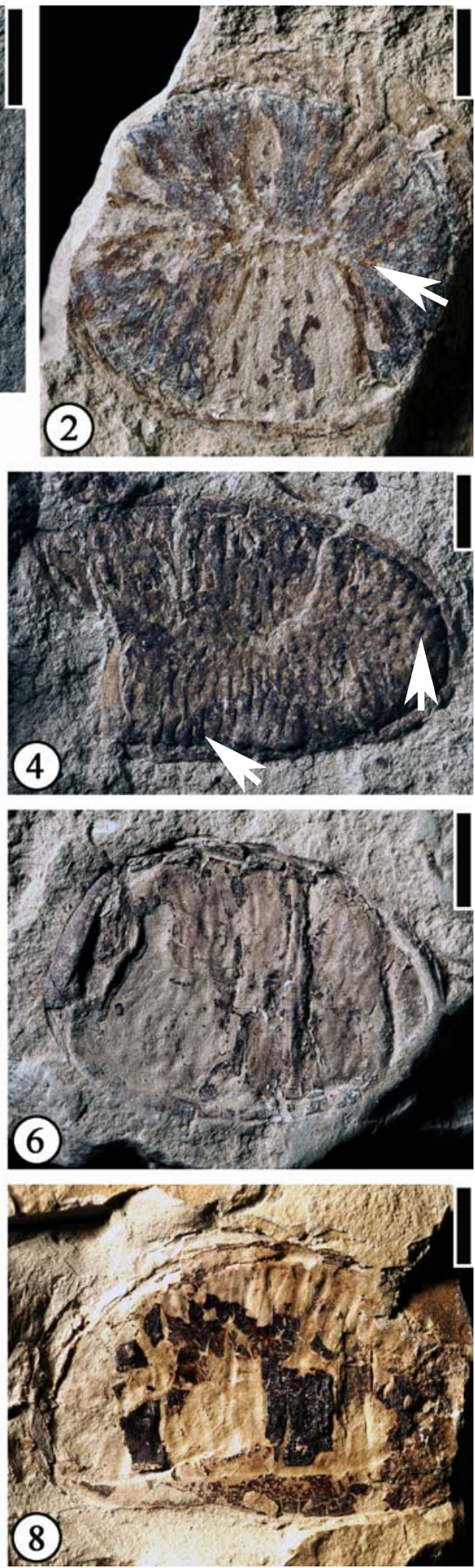

FIGURE 4. Anonaspermum robertsi (Berry) comb. nov. 1. UF15826-33565. Note the relatively smooth seed testa and a reniform seed. Scale bar $=4 \mathrm{~mm}$. 2. UF15826-30837. Note the central line of endosperm (indicated by the arrow). Scale bar $=2 \mathrm{~mm}$. 3. UF15826-51266. Note the thick seed testa. Scale bar $=3 \mathrm{~mm}$. 5. Counterpart of Figure 3.3. Note the thick seed testa. Scale bar $=3 \mathrm{~mm}$. 6. UF15826-53986. Scale bar $=4 \mathrm{~mm}$. 7. UF15826-51289. Scale bar $=3 \mathrm{~mm}$. 8. UF15826-51297. A typical reniform seed. Scale bar $=3 \mathrm{~mm}$. Anonaspermum warmanensis sp. nov. 4. UF1582651284. Note the spiny ruminations (indicated by the arrows). Scale bar $=2 \mathrm{~mm}$. 
seeds of certain of the extant Anonaceae, more especially to those of Anona, Asiminia and Guatteria." Berry (1930) examined 21 specimens from six localities from Kentucky and Tennessee and assigned them to the modern genus Annona. In appearance, the fossils resemble the seeds of extant Annona and Asiminia, but there are parallelism and convergence in seed morphology of different genera of this family (van Setten and KoekNoorman, 1992). Since they are dispersed fossil seeds, we suggest that they all be transferred to the fossil-genus, Anonaspermum. Berry (1930) did not designate a type specimen when he established the new species. Here we designate one of his specimens (USNM146767) as the lectotype.

The ruminations in the seeds of Annonaceae begin to form as infoldings of inner integuments into the soft nucellus when the seed is about half its mature size (Corner, 1949). The ruminations are completed when the endosperm replaces the nucellus. Based on this observation, all seeds observed are probably at their mature or late developmental stage. A vertically compressed seed shows a central line (Figure 4.2, indicated by arrow), which is observed through the transverse section of a modern Annonaceae seed with lamellate ruminations (See van Setten and Koek-Noorman, 1992, p. 4, fig. 3). It is possible that ruminations of other laterally compressed seeds belong to the lamellate type of van Setten and Koek-Noorman (1992, p.4, fig. 3) based upon the thickness and length of the ruminations.

Although ruminations also occur in other fami-

lies (i.e., Myristicaceae, Canellaceae; Parameswaran, 1961), the occurrence of annonaceous leaves from the same clay pit (personal observation) and other localities (Roth, 1981; Dilcher and Lott, 2005) indicate that these seeds are probably related to the Annonaceae. Pollen grains of Annona were also reported from the Lawrence clay pit, Henry County, Tennessee (Elsik and Dilcher, 1974).

\section{Anonaspermum warmanensis sp. nov.}

(Figure 4.4)

Diagnosis. Seed elliptic; seed testa $0.5 \mathrm{~mm}$ thick. Transverse endosperm ruminations present, spiniform.

Description. Laterally compressed seed elliptic, $1.5 \mathrm{~cm}$ long and $0.75 \mathrm{~cm}$ wide. Seed testa $0.5 \mathrm{~mm}$ thick. Transverse endosperm ruminations present, spiniform.

Number of specimens examined. 1. Holotype. Designated here. UF15826-51284 (Figure 4.4).
Discussion. This specimen differs from Anonaspermum robertsi comb. nov. in having spiniform rumimations (see van Setten and Koek-Noorman, 1992, p.4, fig. 3) and thin testa. This interpretation is based upon the vertically compressed tiny holes (indicated by the arrow on the right in Figure 4.4) and the thin spiny ruminations (indicated by the arrow at the bottom in Figure 4.4).

\section{Genus MAGNOLIA Linnaeus, 1753 cf. Magnolia sp.}

(Figure 5)

Description. Compressed sclerotesta elliptic, acute at both ends, $4-5 \mathrm{~mm}$ long and $2-2.5 \mathrm{~mm}$ wide. Seed testa thick with a smooth surface.

Number of specimens examined. 1. UF1582651344 (Figure 5).

Discussion. This specimen is similar to the seeds described by Grote (1989) from the Lamkin clay pit, Kentucky (UF15815) but no internal features or the "fingerprint" pattern of the seed is observed. Tiffney (1977) proposed that the "fingerprint" pattern is produced by the remains of anticlinal walls of cells at the junction of the sclerotesta and the sarcostesta. The "fingerprint" pattern is based upon available characters of the single specimen. We are unable to assign the Warman specimen to either of the two species proposed by Grote (1989).

Order ALISMATALES Dumortier, 1829

Family ARACEAE de Jussieu, 1789

Genus ACORITES Crepet, 1978

Type species. Acorites heeri Crepet, 1978 cf. Acorites heeri Crepet, 1978

(Figure 6)

1930 Acorus heeri Berry, p. 55, pl. 8, fig. 7.

Description. "Spadix" ca $11 \mathrm{~mm}$ long and $2.5 \mathrm{~mm}$ wide with ca 25 sessile circular structures ca $1 \mathrm{~mm}$ in diameter and helically arranged on a $0.5 \mathrm{~mm}$ wide axis.

Number of specimens examined. 1. UF1582633571 (Figure 6).

Discussion. This specimen from the Warman clay pit is superficially similar in appearance to the specimen described from the Lawrence clay pit, Tennessee by Crepet (1978, pl. I, figs. 1-3; 1979, pl. VII, fig. 2) and Berry (1930). Since no floret features, including bilocular anthers and trilocular ovaries with small orbicular stigmas are observed on the current specimen, we use "cf" to indicate that it is similar to but it may not necessarily belong to Acorites heeri. Somewhat similar specimens were described and illustrated by Mai (2001, pl. 9, fig. 12) from the Meuro and Rauno sequences in the Lusatica region of Germany and were assigned to 


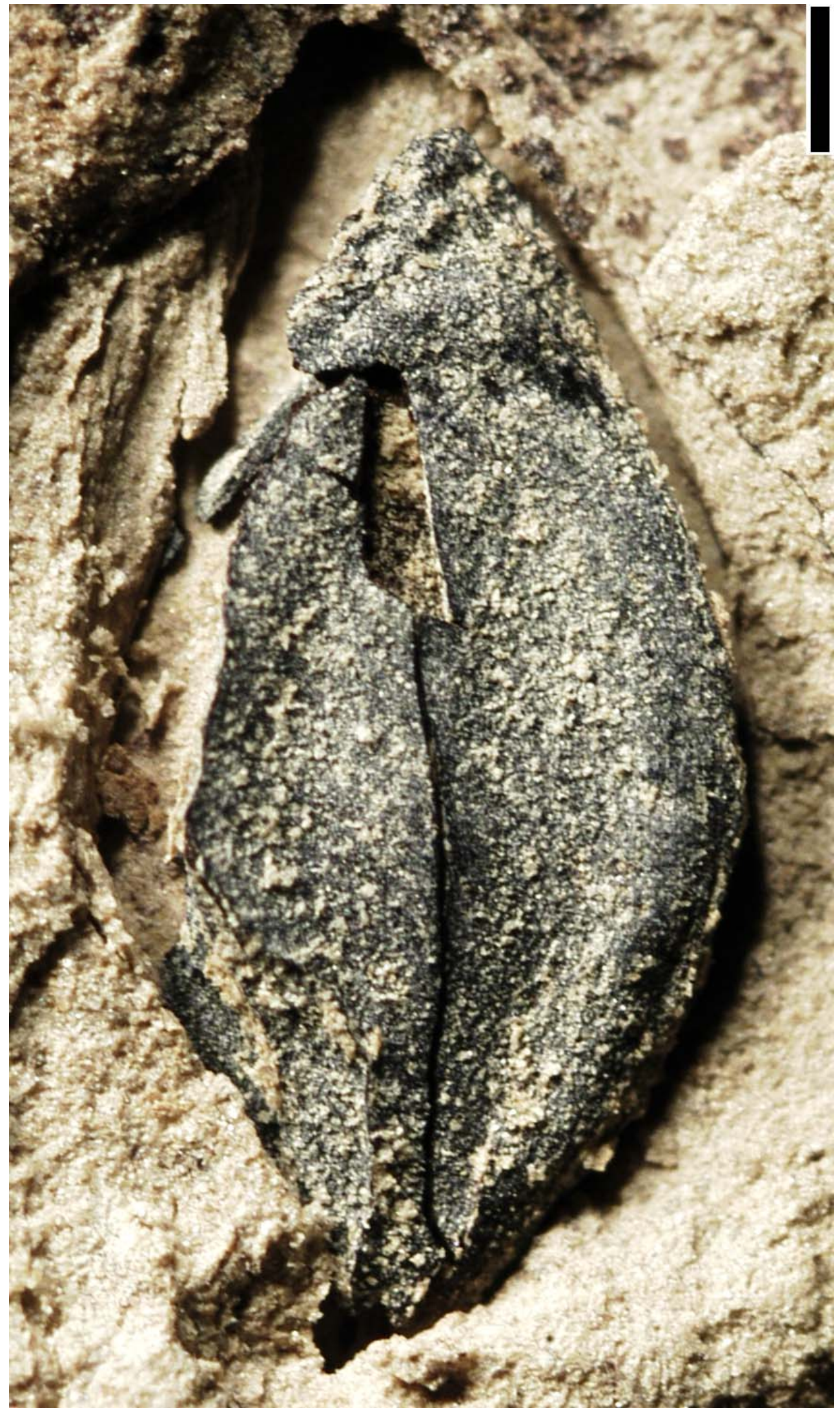

FIGURE 5. cf. Magnolia sp. UF15826-51344. An elliptic seed with a thick testa. Scale bar $=0.5 \mathrm{~mm}$. 


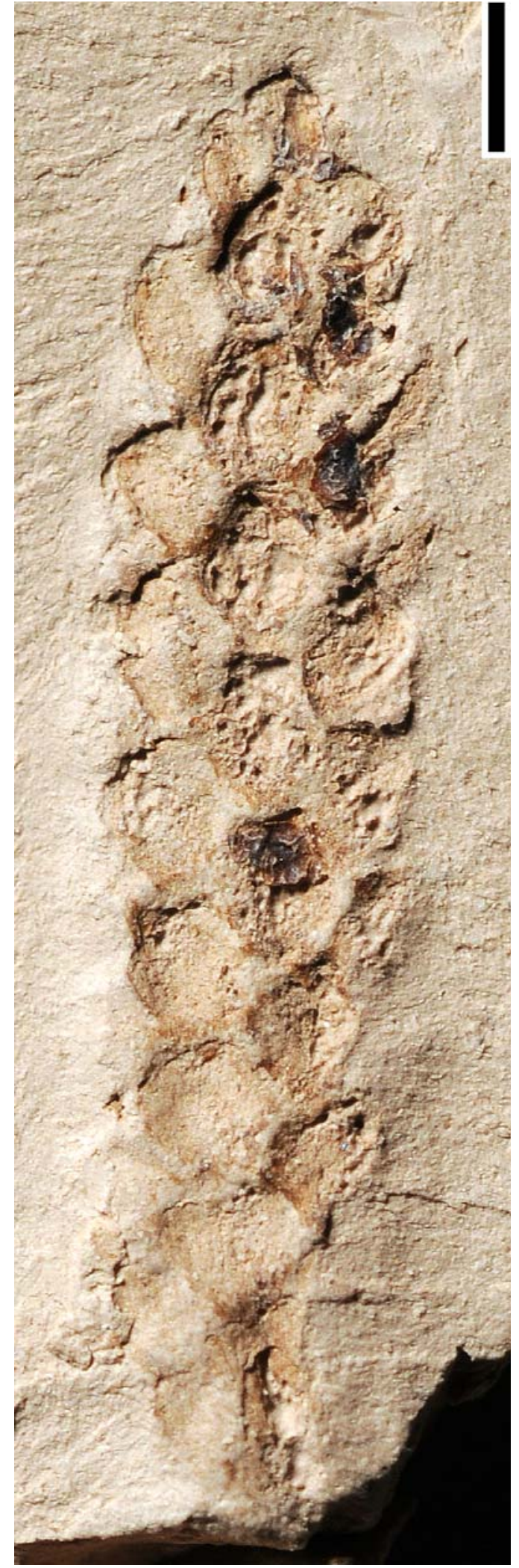

FIGURE 6. cf. Acorites heeri Crepet. UF15826-33571. An incomplete "spadix" showing helically arranged floral parts. Scale bar $=1 \mathrm{~mm}$.
Alnus sp. based upon the presence of Alnus-type of pollen grains, Polyvestibulopollenites verus (R. Potonié) Thomson and Pflug.

Order SAXIFRAGALES Dumortier, 1829

Family cf. ALTINGIACEAE Lindley, 1846 Altingiaceae Infructescence

(Figure 7)

Description. Pedunculate globose infructescences $0.9-1.3 \mathrm{~cm}$ in diameter. Peduncle 1.5-1.7 $\mathrm{cm}$ long and $2 \mathrm{~mm}$ wide with smooth surface. Fruits narrowly elliptic or narrowly oblong, 3-6 mm long and 1-2 $\mathrm{mm}$ wide, clustered together without obvious central receptacle cores exposed. No obvious styles observed on the distal ends of the fruits. At least 10-16 fruits in each infructescence.

Number of specimens examined. $>10$. UF1582633568 (Figure 7.1); 33569 (Figure 7.2).

Discussion. The infructescences are similar to the extant infructescences of Altingia and Liquidambar in gross morphology. Dilcher and Lott (2005; p. 12, figure 18d, 18h) reported a Liquidambar sp. infructescence from the Powers clay pit locality (UF18810). This infructescence is the same type as that from the Warman clay pit. The lack of obvious persistent styles indicates that this infructescence type may be more closely related to the genus Altingia rather than Liquidambar since persistent styles and stigmas are typical features of mature infructescences of Liquidambar but are lacking in Altingia (Bogle, 1986; Ferguson, 1989; Ickert-Bond et al., 2005, 2007). However, pollen of Liquidambar is recorded from the upper Claiborne of Alabama (Gray, 1960) but no pollen of Altingia has been reported.

Family HAMAMELIDACEAE Brown, 1818

Genus CORYLOPSIS Siebold and Zuccarini, 1836 Corylopsis grotei sp. nov.

(Figure 8)

Diagnosis. Seeds elliptic, 8-11 mm long and 4.2$6.6 \mathrm{~mm}$ wide; hilum slightly depressed, asymmetric, with two arms extending from near the apex down the ventral and dorsal sides of the seed, one arm being shorter than the other.

Description. Seeds mostly dorsoventrally compressed although some laterally compressed. Dorsoventrally compressed seeds elliptic, $8-11 \mathrm{~mm}$ long and 4.2-6.6 $\mathrm{mm}$ wide. Hilum slightly depressed, asymmetric, with two arms extending from near the apex down the ventral and dorsal sides of the seed, one arm being shorter than the other. Width of the longer hilar arm 1.2-1.7 mm. Surface of seed coat consisting of elliptic cells, lon- 

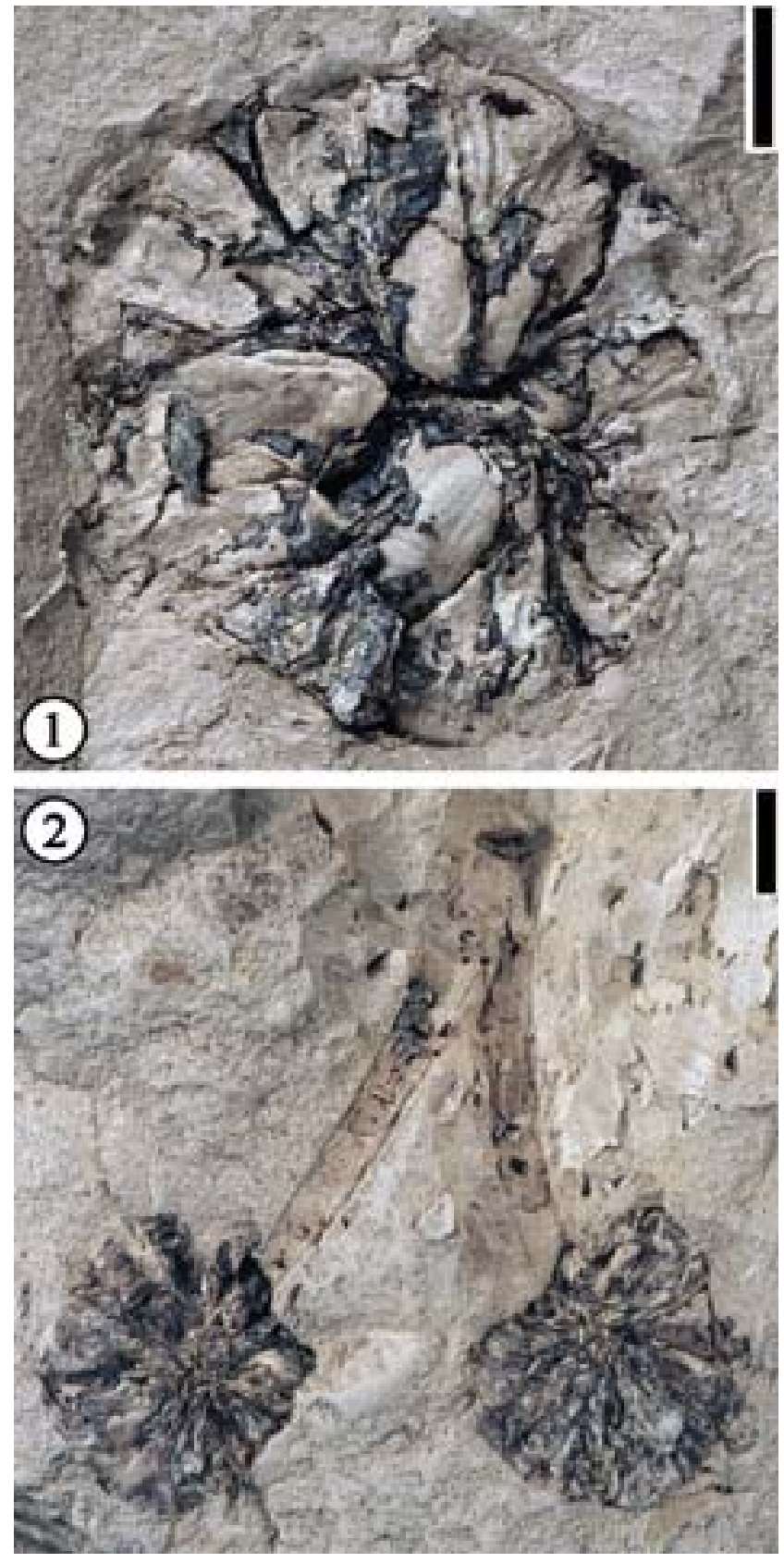

FIGURE 7. Altingiaceae Infructescence.1. UF15826-33568. Showing the fruits of an infructescence. Scale bar $=2$ $\mathrm{mm}$. 2. UF15826-33569. Showing two pedunculate infructescences. Note the long peduncles. Scale bar $=3 \mathrm{~mm}$.

gitudinally aligned in some areas, especially toward the chalazal half of the seed. In other areas, the cells oriented in various directions, forming a swirling pattern. Inner surface of seed coat consisting of a layer of parallel, transversely elongate cells.

Number of specimens examined. 7.

Holotype. Designated here. UF15826-9111 (Figure 8.1-2).
Additional specimens. UF15826-9056 (Figure 8.3-4).

Discussion. Grote (1989) studied the morphology and surface anatomy of seeds in 22 extant genera and 36 extant species of Hamamelidaceae (including 16 genera and 27 species in Hamamelidoideae). Based upon available information about the fossil seeds, i.e., the shapes of the seeds and the hilar scar, the fossil specimens are considered 
an extinct species of the extant genus Corylopsis. We use the species epithet, grotei, to recognize Paul Grote's contribution to the study of fossil plants from the Eocene Claiborne Group of southeastern United States.

Compared with similar European species, Corylopsis grotei differs from Corylopsis venablesi, Corylopsis? bognorensis, Corylopsis? latisperma, and Genus? (Hamamelidaceae) from the Lower Eocene of England (Reid and Chandler, 1933; Chandler, 1961) and upper Eocene of Germany (Mai and Walther, 1985), and Corylopsis minima from the upper Eocene of Germany (Mai and Walther, 1985) in having a larger seed size and a longer hilar scar.

While the seeds of several genera within the Hamamelidoideae appear to be indistinguishable, seeds of the genus Corylopsis are distinct because of their large, very asymmetrical, narrow hilar scar. Hamamelidaceous pistillate inflorescences, flowers, fruits, and pollen grains have been reported from the Late Cretaceous of Sweden (late Santonian or Early Campanian; Endress and Friis, 1991) and the United States [Georgia (Campanian; Magallon-Puebla et al., 1996) and New Jersey (Raritan Formation; Crepet et al., 1992; Zhou et al., 2001)] . These results suggest that the Hamamelidaceae has a long geological history.

Genus HAMAMELIS Linnaeus, 1753 Hamamelis warmanensis sp. nov.

(Figure 9)

Diagnosis. Fruit two-valved capsule, longitudinally dehiscent. Each fruit attached to a peduncle. Receptacle present, about half the length of the fruit. Hypanthium rim present. Stylar projection present on the capsule.

Description. Fruit two-valved capsule, $1.5 \mathrm{~cm}$ long and $1 \mathrm{~cm}$ wide, longitudinally dehiscent. Each fruit attached to a peduncle $2.5-3 \mathrm{~cm}$ long and up to 2 $\mathrm{mm}$ wide. Receptacle present, about half the length of the fruit. Hypanthium rim present. Stylar projection present on the capsule.

Species epithet. Referring to the occurrence of this species in Warman clay pit, Tennessee.

Holotype. Designated here. UF15826-33567 (Figure 9).

Number of specimens examined. 1.

Discussion. The specimen has two fruits attached to long pedicels. It is assigned to the extant genus Hamamelis based upon its two-valved capsule that is longitudinally dehiscent. Each fruit has a long pedicel while extant Hamamelis capsules have short pedicels and they are usually clustered together. This species may represent another bal- listically dispersed member of the Hamamelidaceae (Tiffney, 1986).

This species is similar to Carpolithus collinsi (see FRUITS AND SEEDS) in that both fruits are transversely delineated into a lower hypanthium and an upper fruit body. They differ in that the upper fruit body (capsule) of Hamamelis warmanensis is dehiscent.

Order FABALES Bromhead, 1838

Family FABACEAE Lindley, 1836

A diverse assemblage of fossil legumes from the Eocene of southeastern North America has been reported and summarized by Herendeen (1992; also see Herendeen and Dilcher, 1990a, b, c; Herendeen and Dilcher, 1991). The descriptions that follow are mainly adopted from these publications.

Genus EOMIMOSOIDEA Crept and Dilcher, 1977

Type species. Eomimosoidea plumosa Crepet and Dilcher, 1977

Eomimosoidea plumosa Crepet and Dilcher, 1977

(Figures 10, 11)

Description. Inflorescence at least $6 \mathrm{~cm}$ long, axis $0.7-1 \mathrm{~mm}$ wide. Flowers bisexual, helically arranged on the axis; flowers sessile, ovate, ca 2$2.5 \mathrm{~mm}$ long and 1.5-2 $\mathrm{mm}$ wide with 4 or 5 stamens in each flower. Perianth ovate, $2 \mathrm{~mm}$ long and $1.5 \mathrm{~mm}$ wide; filaments thin, up to $8 \mathrm{~mm}$ long and $0.2 \mathrm{~mm}$ wide; anthers ca $0.5 \mathrm{~mm}$ in diameter with longitudinal dehiscence; styles $2.5 \mathrm{~mm}$ long and $1 \mathrm{~mm}$ wide. One auricular bract in each flower, $0.8 \mathrm{~mm}$ long and $1-1.2 \mathrm{~mm}$ wide. Simple trichomes present on style, perianth, and bract.

Number of specimens examined. 22.

Holotype. UF15826-2230, designated in Crepet and Dilcher (1977, figs. 2, 5).

Additional specimens. UF15826-51348 (Figure 11.4-5); 36564 (Figure 10); 51387 (Figure 11.3); 51518 (Figure 11.1-2).

Discussion. Crepet and Dilcher (1977) first described a mimosoid inflorescence based upon specimens from the Warman clay pit. Daghlian et al. (1980) extended the range of this species based upon younger specimens from Huntsville, Texas (Oligocene), noting that Eomimosoidea plumosa had changed little during the middle Eocene-Oligocene interval.

\section{Genus PROTOMIMOSOIDEA Crepet and Taylor,} 1986

Type species. Protomimosoidea buchananensis Crepet and Taylor 1986 

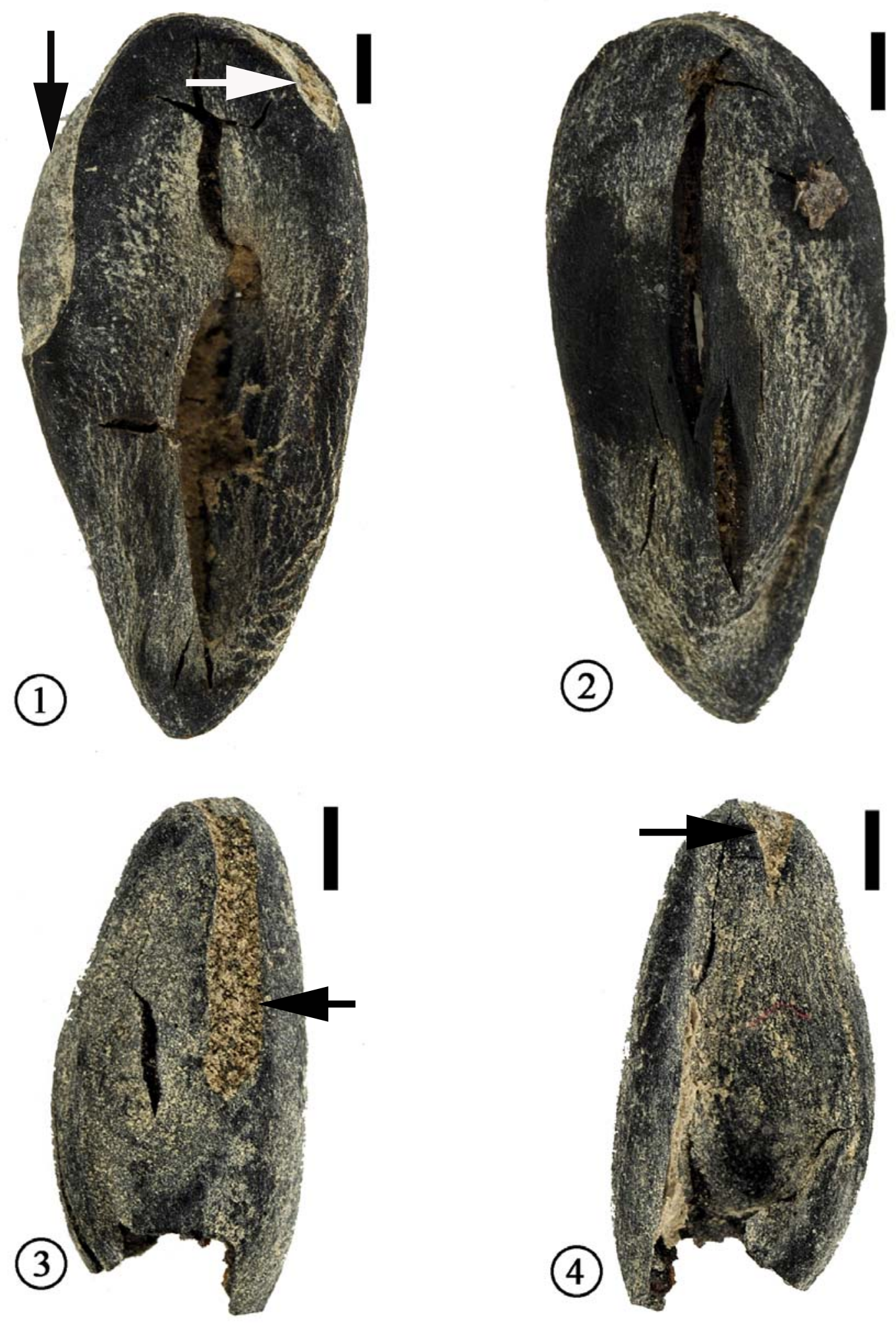

FIGURE 8. Corylopsis grotei sp. nov. All scale bars equal $1 \mathrm{~mm}$. 1. UF15826-9111. Showing an asymmetric hilum with two arms (indicated by arrows). 2. Opposite side of Figure 8.1. 3. UF15826-9056. Showing the longer arm of an asymmetric hilum scar (indicated by arrow). 4. Opposite side of Figure 8.3 showing the shorter arm of an asymmetric hilum scar (indicated by arrow). 

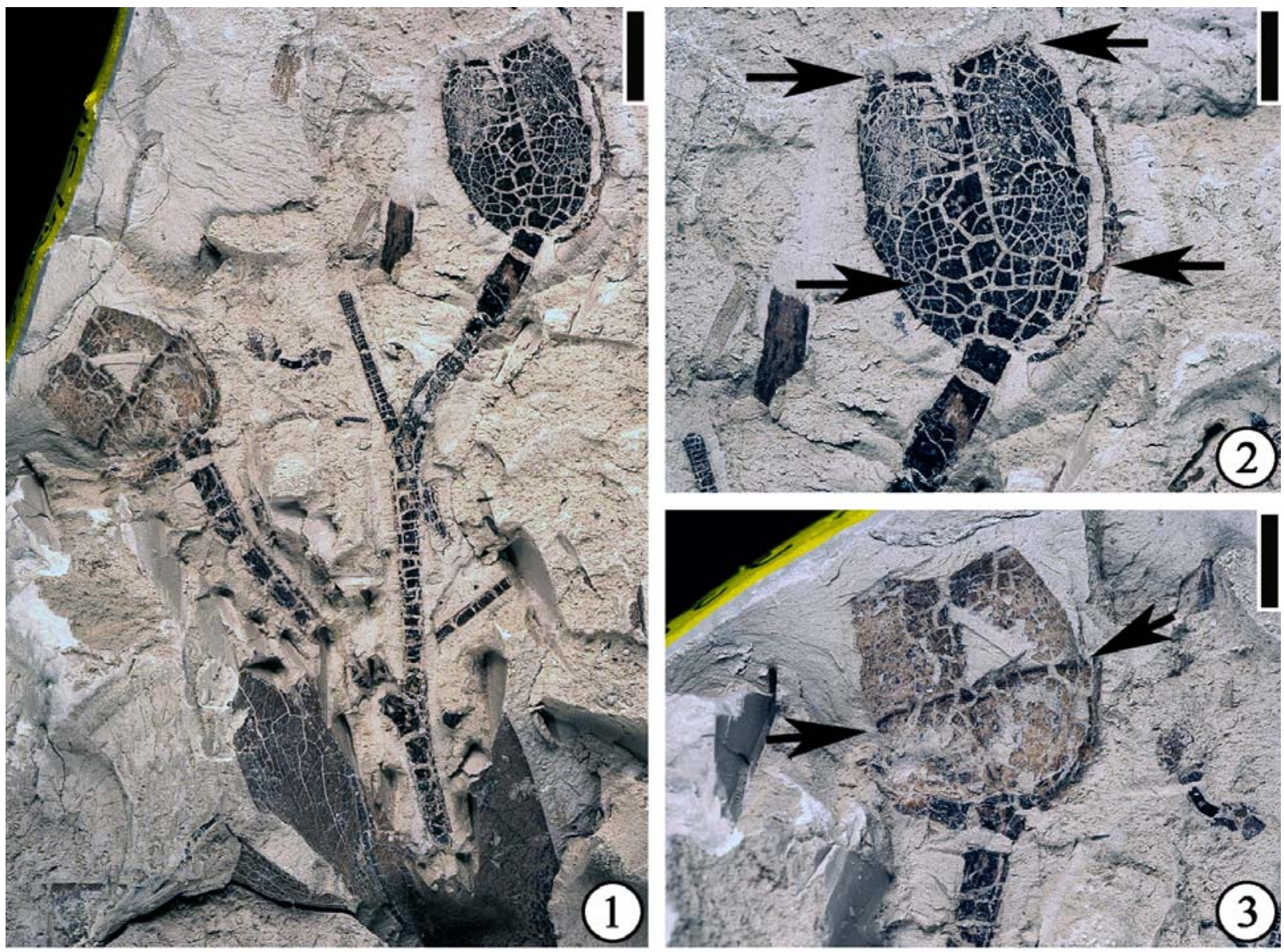

FIGURE 9. Hamamelis warmanensis sp. nov. 1. UF15826-33567. Showing two fruits with long peduncles attached to the stem. Scale bar $=6 \mathrm{~mm}$. 2. Enlargement of Figure 9.1 to show stylar projections (indicated by two upper arrows) and capsule valves (indicated by two lower arrows). Scale bar $=4 \mathrm{~mm}$. 3. Enlargement of Figure 9.1 to show another fruit. Note the demarcation between the lower cupule and the upper fruit body (indicated by arrows). Scale bar $=4 \mathrm{~mm}$.

\section{Protomimosoidea buchananensis Crepet and Taylor, 1986 \\ (Figure 12)}

Description. Flowers ca $4 \mathrm{~mm}$ long and $3 \mathrm{~mm}$ wide (excluding filaments and pedicel) with at least eight stamens. Filaments thin, at least $3 \mathrm{~mm}$ long. Anthers ca $0.5 \mathrm{~mm}$ long and $0.3 \mathrm{~mm}$ wide. Petals triangular, small, ca $1.2-1.5 \mathrm{~mm}$ long and $0.5-2$ $\mathrm{mm}$ wide. Two sepals and three petals per flower; sepals elliptic to narrow elliptic, small, half the length of petals. Ovaries 1.5-1.8 $\mathrm{mm}$ wide and 1 $\mathrm{mm}$ long. Compressed receptacle, triangular in outline ca $0.3 \mathrm{~mm}$ long and $1.3 \mathrm{~mm}$ wide; pedicel up to $6 \mathrm{~mm}$ long and $1 \mathrm{~mm}$ wide.

Number of specimens examined. 4. UF1592633554 (Figure 12.1); 33559 (Figure 12.2); 51359 (Figure 12.3); 8956 (Figure 12.4).
Discussion. Characters of these specimens are consistent with the materials described by Crepet and Taylor (1986). Flowers of this species have been reported from the Warman, Buchanan, and Puryear clay pits of western Tennessee. Crepet (1979, plate V, fig. 1) suggested that flowers of this species are wind pollinated.

Genus CAESALPINIA Linnaeus, 1753

Caesalpinia claibornensis Herendeen and Dilcher, 1991

(Figure 13.4-5)

Description. Fruits $5.1-8.1 \mathrm{~cm}$ long and $1.2-2.1$ $\mathrm{cm}$ wide (excluding the wing) with a continuous vascularized wing along placental suture ca 3.5-9 $\mathrm{mm}$ wide. Wing usually wider at the fruit center than at the ends. Fruits thin and membranous with acute to obtuse base, blunt and rounded or occasionally mucronate apex and persistent style base. 

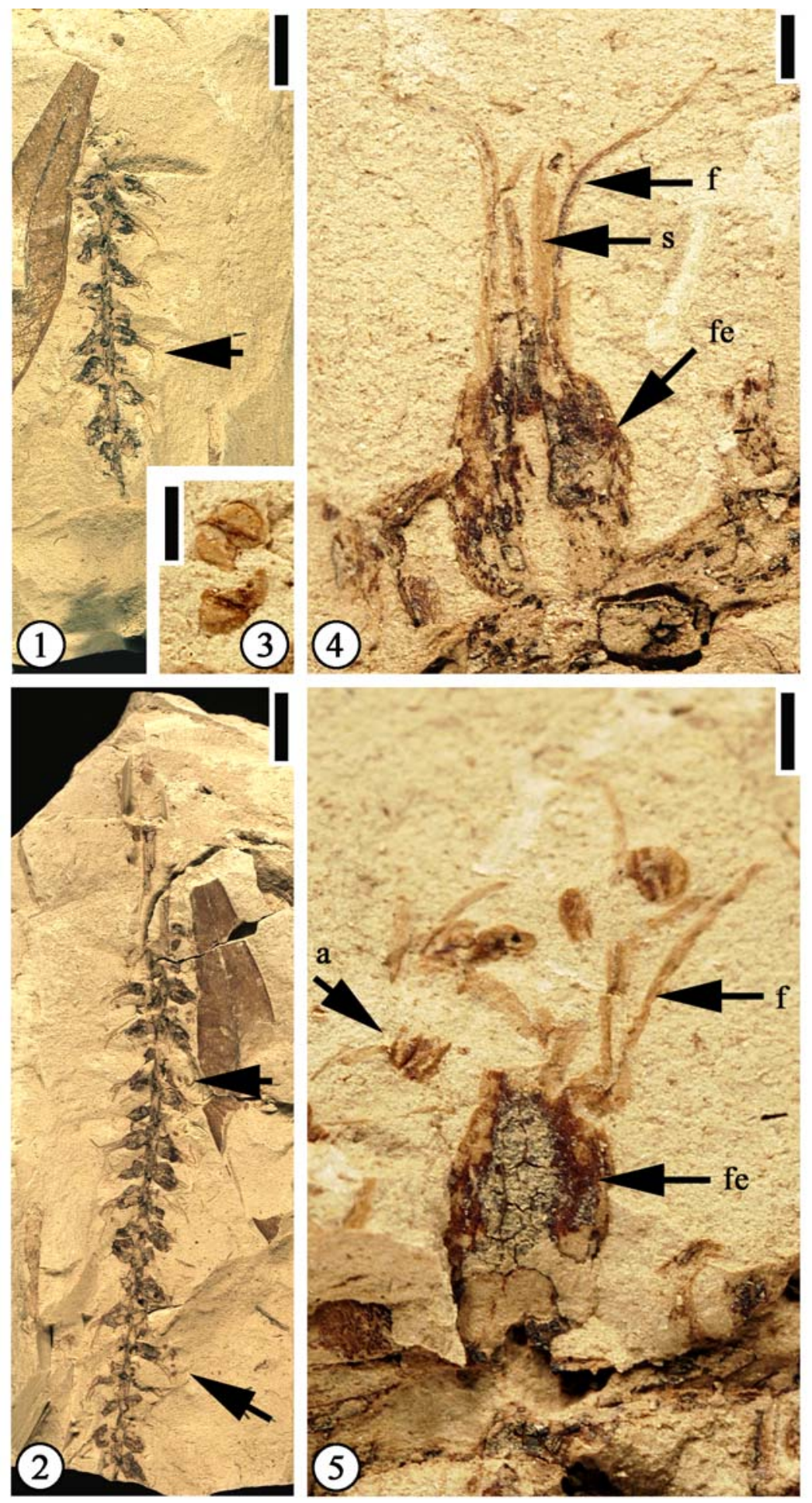

FIGURE 10. Eomimosoidea plumosa Crepet and Dilcher. 1. UF15826-33564. Showing an incomplete catkin. Arrow indicates a flower enlarged in Figure 10.4. Scale bar $=6 \mathrm{~mm}$. 2. Counterpart of Figure 10.1 showing nearly complete length. Scale bar $=6 \mathrm{~mm}$. 3. Enlargement of two dispersed anthers in Figure 10.2 (indicated by top arrow) showing a globose anther and longitudinal dehiscence. Scale bar $=0.5 \mathrm{~mm}$. 4. Enlargement of a flower in Figure 10.1 (indicated by the arrow) showing a floral envelope (fe), a style and a stigma (s), and filaments (f). Scale bar $=0.5 \mathrm{~mm}$. 5 . Enlargement of a flower in Figure 10.2 (indicated by the bottom arrow) showing a floral envelope (fe), filaments (f), and dispersed anthers (a). Scale bar $=0.5 \mathrm{~mm}$. 

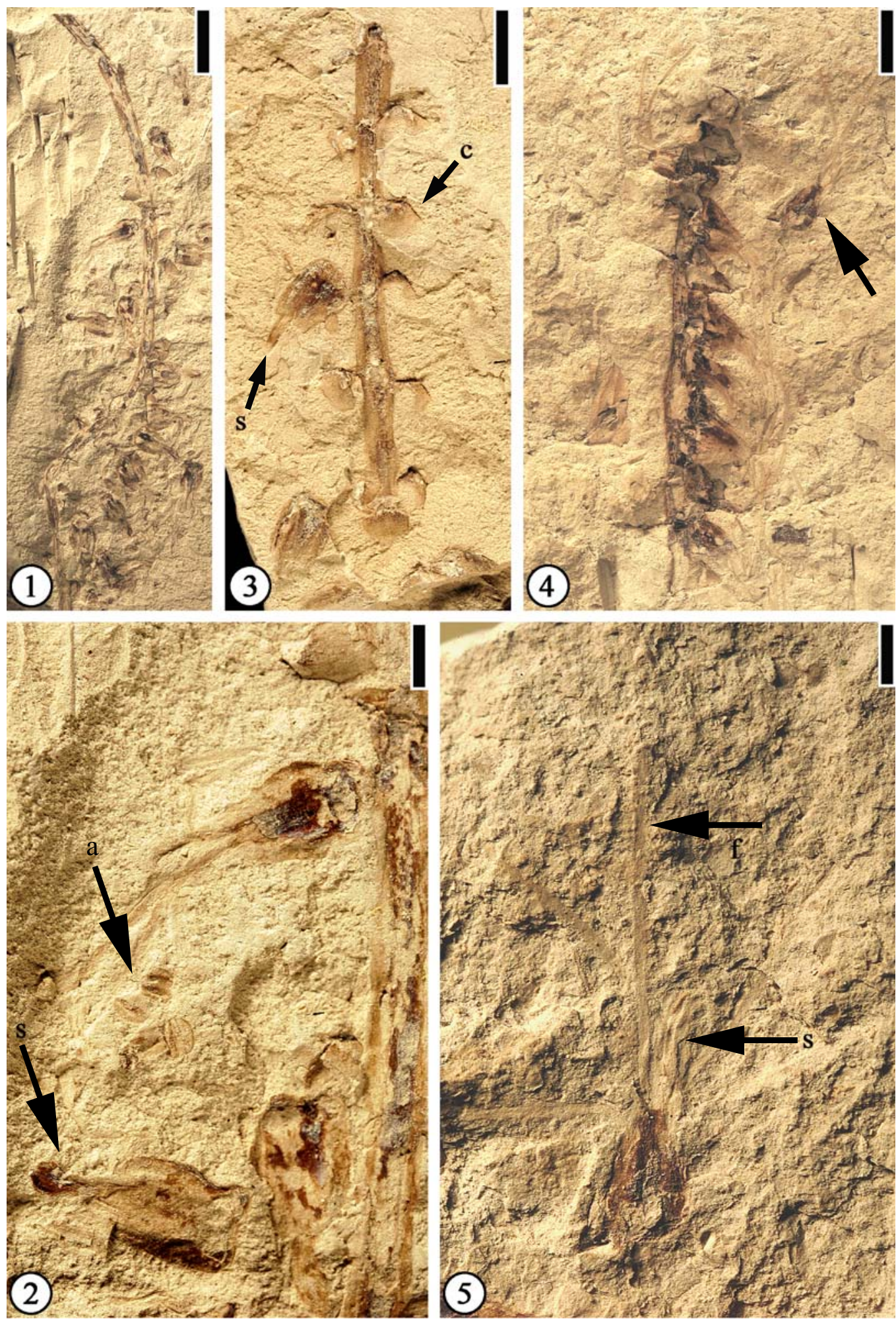

FIGURE 11. Eomimosoidea plumosa Crepet and Dilcher. 1. UF15826-51518. An incomplete catkin. Scale bar $=5$ $\mathrm{mm}$. 2. Enlargement of Figure 11.1 showing dispersed anthers (a), a style and a stigma (s) of a flower. Scale bar $=1$ $\mathrm{mm}$. 3. UF15826-51387. An incomplete catkin showing calyx (c), and a style and a stigma (s) of a flower. Scale bar = $1 \mathrm{~mm}$. 4. UF15826-51348. An incomplete catkin showing attached and dispersed sessile flowers. Arrow indicates the flower enlarged in Figure 11.5. Scale bar $=3 \mathrm{~mm}$. 5. Enlargement of a flower in Figure 11.4 showing a style and a stigma (s), and filaments (f). Scale bar $=1 \mathrm{~mm}$. 
Fruits short stipitate with three to several ovules; Fruit valve venation consisting of numerous closely spaced primary veins arising from the placental and non-placental sutures at $90^{\circ}$ angles; Veins dividing and anastomosing to form a fine reticulum. Wing venation consisting of a poorly organized storied looping pattern with veins arising from the placental suture, dividing several times, and returning toward the suture. Valve venation often better preserved than wing venation.

Number of specimens examined. 22. UF158265853 (Figure 13.4-5).

Discussion. This specimen is the holotype and one of many specimens from the Warman clay pit described by Herendeen and Dilcher (1991, figs. $1-12,34$, p. 3-4). This species is placed in Caesalpinia because the outline of a symmetrical seed remaining within a seed chamber is suggestive of a caesalpiniod/minosoid seed type.

\section{Genus CRUDIA von Schreber, 1789}

Type species. Crudia grahamiana Herendeen and Dilcher, 1990c

Crudia grahamiana Herendeen and Dilcher, 1990c (Figure 13.6)

Description. Fruit ovate, $5 \mathrm{~cm}$ long and $3 \mathrm{~cm}$ wide; apex rounded, base tapered; attachment offset from fruit midline and positioned near non-placental suture; marginal suture thick $(2 \mathrm{~mm})$; bearing two ovules; at least four orders of venation present with the thickest veins arranged transverse to fruit axis; veins interconnected to form prominent reticulum.

Number of specimens examined. 1. UF158265869 (Figure 13.6).

Discussion. This specimen is the paratype from the Warman clay pit described by Herendeen and Dilcher (1990c, fig. 3, p. 404-406). Based upon extensive survey of modern legume fruits, Herendeen and Dilcher (1990c) suggested that this fruit is most comparable to fruits of Crudia because the fruit bears two seeds and the shape and position of the ovules in the fossil are similar to that observed in the dissected young fruit from $C$. acuminata Bentham. On the contrary, fruits of other genera, including Brownea, Brodriguesia, and Macrolobium bear variable numbers of seeds and their ovules are located near the placental suture.

Crudia is a pantropical genus with ca 55 species, of which 10 occur in tropical America, eight in the Guineo-Congolian region of Africa, and the rest in Asia (mostly Malesian) (Sanjappa, 1994).

Genus DIPLOTROPIS Bentham, 1837 Diplotropis claibornensis Herendeen and Dilcher,
$1990 \mathrm{~b}$

(Figure 14.1)

Description. Fruit a stipitate pod, oblong to oblanceolate with a rounded apex and tapering base, thin and membranous. Placental suture supporting a narrow, nonvascularized wing. Fruit body consisting of three longitudinal zones: a central thicker zone and two flanking thinner zones. Primary veins of the valves oblique and irregular in course from the sutures to the fruit center, where they form a fine reticulum. Primary veins dividing several times before entering the central zone. Venation of the lateral zones more prominent than that of the central zone.

Number of specimens examined. 1. UF158267235 (Figure 14.1).

Discussion. The assignment of this specimen to Diplotropis is significant in that members of the extant genus are restricted today to tropical South America (Herendeen and Dilcher, 1990b). Other fossils from the Eocene of southeastern United States may have their closest relatives to extant taxa that occur today in South America, but most of them are assigned to extinct genera (Roth and Dilcher, 1979; Daghlian et al., 1980; Dilcher and Manchester, 1986; Taylor, 1988; Herendeen and Dilcher, 1990a; Stull et al., 2011; Stull et al., 2012).

Genus ELIASOFRUCTUS Herendeen and Dilcher, 1990a

Type species. Eliasofructus claibornensis Herendeen and Dilcher, 1990a

Eliasofructus claibornensis Herendeen and Dilcher, $1990 \mathrm{a}$

(Figure 14.2)

Description. Fruit a stipitate pod, at least $11.5 \mathrm{~cm}$ long and $4 \mathrm{~cm}$ wide with a broadly rounded apex, and containing 10 seeds. Seed chambers transverse, rectangular, straight to slightly curved toward the base of the fruit near the nonplacental suture. Seeds oblong to ovate with a thick, short funiculus. Fruit indehiscent with a straight to slightly constricted margin. Coalesced vascular bundles evident along the margin.

Number of specimens examined. 1. UF158265842 (Figure 14.2; Herendeen and Dilcher 1990a, plate VI, fig. 4)

Discussion. The specimen illustrated here is the holotype from the Warman clay pit described by Herendeen and Dilcher (1990a, plate VI, fig. 4, p. $355)$. This species also occurs at the Lamkin clay pit, Kentucky. Based upon co-occurrence, similar anatomical features and similarity to an extant genus, Herendeen and Dilcher (1990a) suggested 

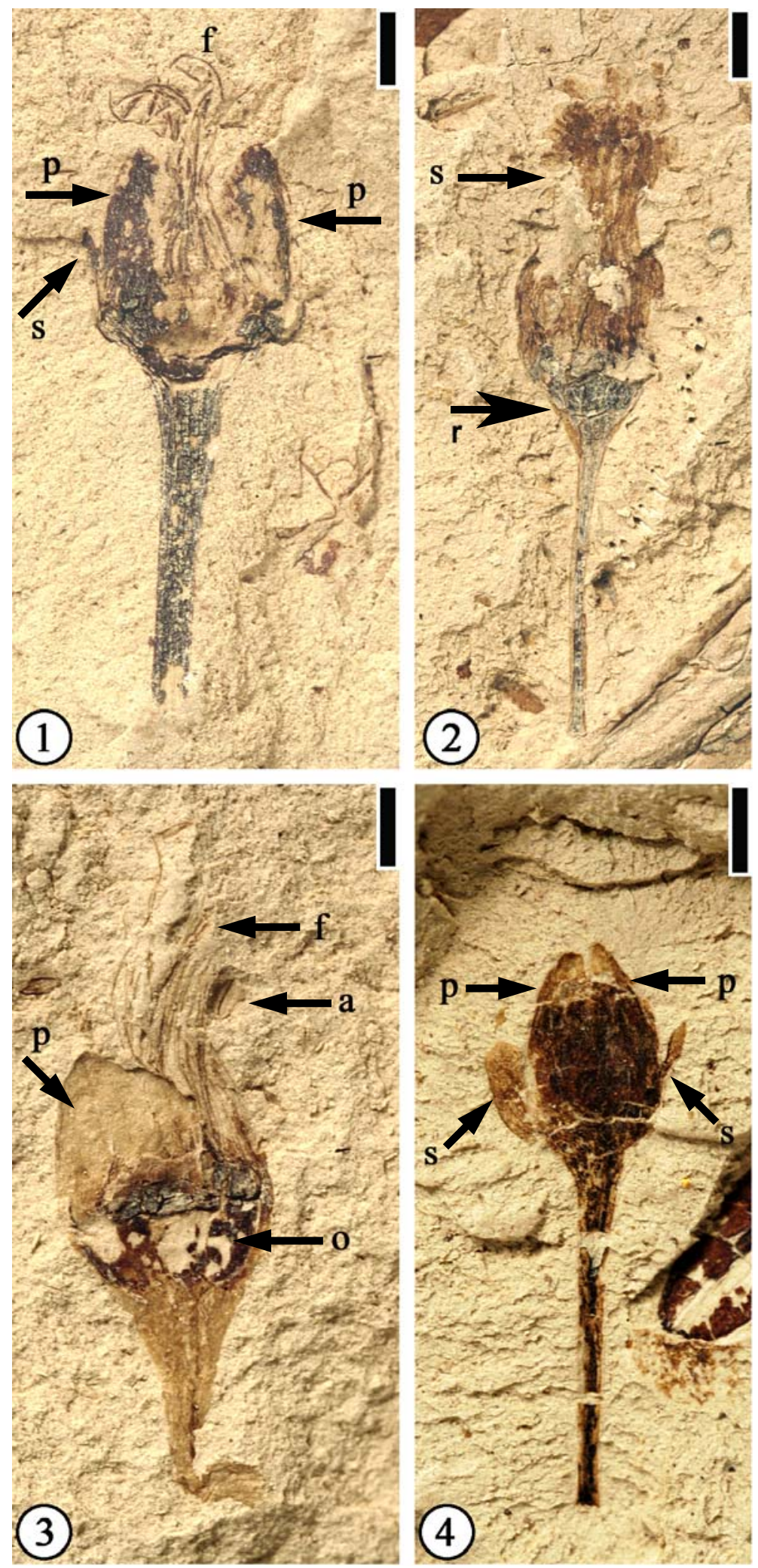

FIGURE 12. Protomimosoidea buchananensis Crepet and Taylor. All bars $=1 \mathrm{~mm}$. 1. UF15926-33554. A laterally compressed flower showing filaments (f), valvate petals (p), and sepals (s). 2. UF15826-33559. A laterally compressed flower with a triangular receptacle ( $r$ ) and stamens (s). 3. UF15826-51359. A laterally compressed flower showing an ovary (o), a petal ( $p$ ), a dispersed anther (a), and filaments (f). 4. UF15826-8956. A laterally compressed flower bud showing sepals $(s)$ and petals $(p)$. 


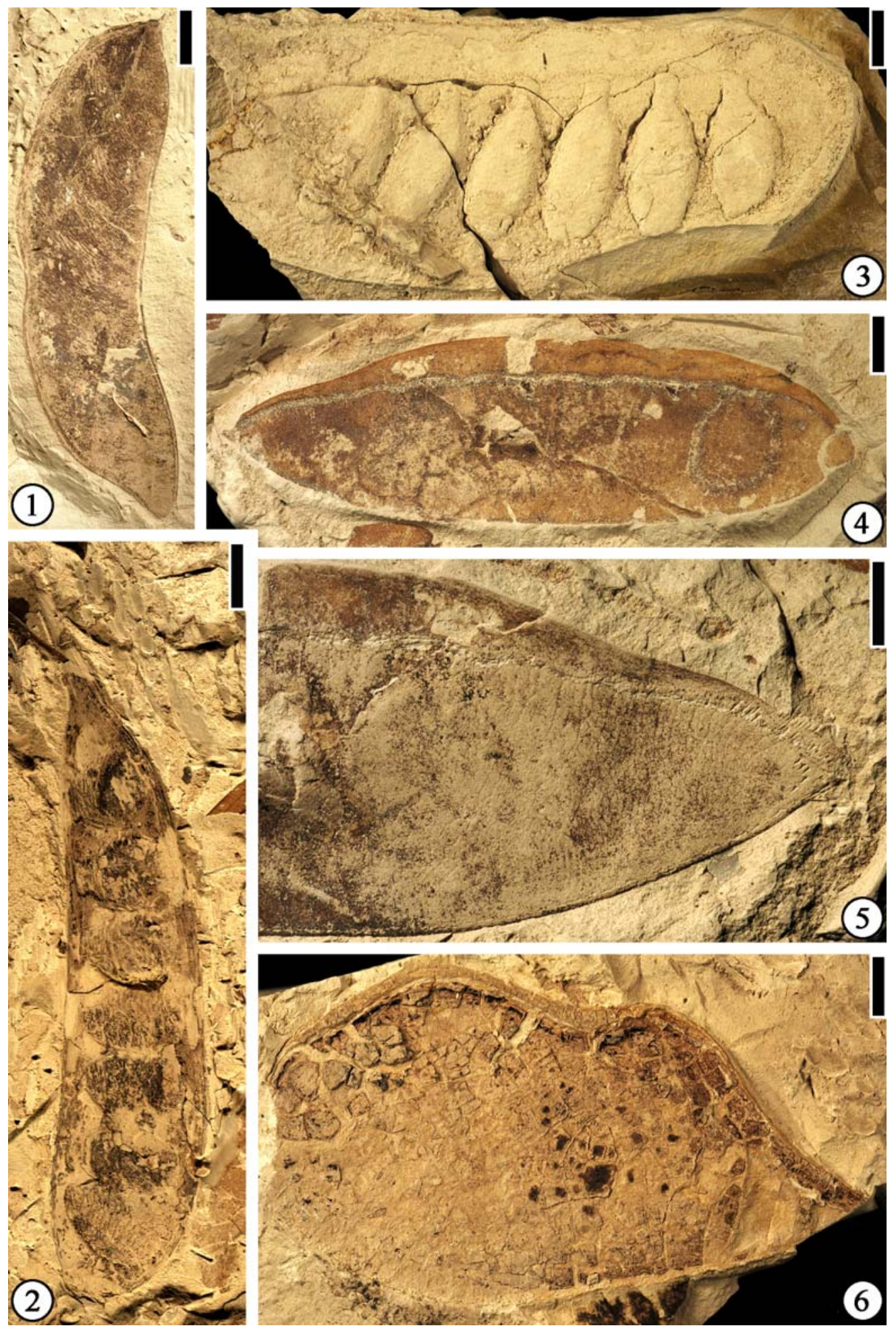

FIGURE 13. Swartzia sp. 1. UF15826-9041. A pod showing a narrow flange and a short remnant style . Scale bar $=1$ $\mathrm{cm}$. cf. Erythrophleum sp. 2. UF15826-5829. A pod with a stipitate base and impressions of 7 seeds. Scale bar $=1$ $\mathrm{cm}$. cf. Leguminosites phyllocarpoides Berry. 3. UF15826-5839. An incomplete pod showing impressions of 6 seeds. Scale bar $=8 \mathrm{~mm}$. Caesalpinia claibornensis Herendeen and Dilcher. 4. UF15826-5853. A pod showing outlines of seed chambers. Scale bar $=7 \mathrm{~mm}$. 5. Base of counterpart of Figure 13.4 showing venation of a valve and a wing. Scale bar $=5 \mathrm{~mm}$. Crudia grahamiana Herendeen and Dilcher. 6. UF15826-5869. A pod showing a marginal suture. Scale bar $=5 \mathrm{~mm}$. 

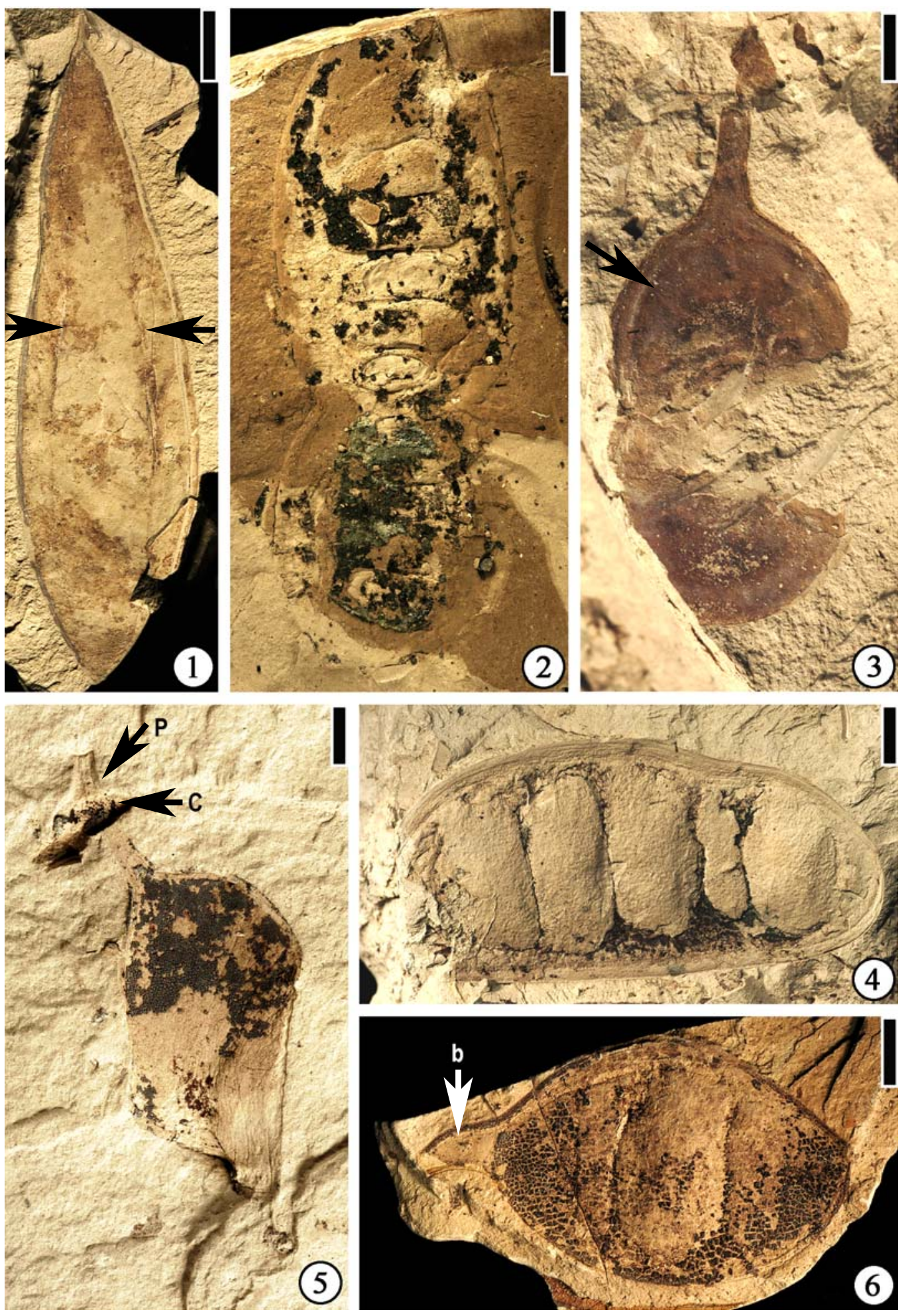

FIGURE 14. Diplotropis claibornensis Herendeen and Dilcher. 1. UF15826-7235. Pod showing three zones (boundaries indicated by arrows) of the fruit. Scale bar $=7 \mathrm{~mm}$. Eliasofructus claibornensis Herendeen and Dilcher. 2. UF15826-5842. Showing outlines of 10 seeds. Scale bar $=1 \mathrm{~cm}$. Gleditsia ? mississippiensis (Berry) Berry. 3 . UF15826-7066. Showing thick seed chamber (indicated by arrow). Scale bar $=2 \mathrm{~mm}$. "Thick walled fruit". 4. UF15826-5835. Showing four normal seed chambers and a single small one. Scale bar $=5 \mathrm{~mm}$. Ormosia sp. 5 . UF15826-51357b. Showing a young fruit with a pedicel (p), a calyx (c), and valve venation. Scale bar $=3 \mathrm{~mm}$. 6 . UF15826-5820. Showing the seed base (b) and three seed chambers. Scale bar $=5 \mathrm{~mm}$. 
that Duckeophyllum eocenicum leaflets, Eomimosoidea plumosa and Eliasofructus fruits were produced by the same species of plant.

Genus GLEDETSIA Linnaeus, 1753

cf. Gledetsia? mississippiensis (Berry) Berry, 1930

(Figure 14.3)

Description. Fruits small pods, round to oblong or ovate with rounded apex and base, $1.5-1.9 \mathrm{~cm}$ long and $0.9-1 \mathrm{~cm}$ wide, stipitate $(2-5 \mathrm{~mm}$ long). Valves coriaceous.

Number of specimens examined. 2. UF158267066 (Figure 14.3).

Discussion. This specimen is one of the two fossils from the Warman clay pit described by Herendeen (1992, figs. 225-230, pp. 128-129). Another specimen from the Bolden clay pit, Mississippi was also described. They were considered similar to those specimens described by Berry $(1916,1930)$. The systematic position of these fruits within the Fabaceae is uncertain because of insufficient information even though the thickened central seed chamber (Herendeen, 1992, figs. 225-230; Figure 14.3 ) is suggestive of the Dalbergieae and Millettieae tribes.

\section{Genus cf. ERYTHROPHLEUM Afzelius and Brown, 1826 \\ cf. Erythrophleum sp.}

(Figure 13.2)

Description. Fruit a pod. Outline slightly falcate, $10 \mathrm{~cm}$ long and $2.5 \mathrm{~cm}$ wide; apex rounded, base tapered, stipitate (ca $2 \mathrm{~cm}$ long); seeds 7 , rounded to elliptical in outline, $1.2-2 \mathrm{~cm}$ long and $1.2 \mathrm{~cm}$ wide; funiculus short and thick; fruit margin straight; sutures well developed.

Number of specimens examined. 1. UF158265829 (Figure 13.2).

Discussion. This specimen was described by Herendeen in 1992, (figs. 1, 2, p. 89). Three other specimens (Herendeen, 1992, figs. 3-5) are from Lawrence, New Lawrence, and Lamkin localities in Kentucky. Based upon fruit characters (slightly falcate outline and rounded apex in all four specimens and stipitate base in the Warman and New Lawrence specimens), Herendeen (1992) suggested that the four specimens at least represent the same genus even though they may not all represent the same taxon.

Genus LEGUMINOSITES Bowerbank, 1840 cf. Leguminosites phyllocarpoides Berry, 1930

(Figure 13.3)

Description. Fruits $11 \mathrm{~cm}$ long and $3.4-3.8 \mathrm{~cm}$ wide with a rounded apex, a straight margin, and containing at least 5-7 seeds. Seeds elliptical, transversely oriented, $1.9-2.2 \mathrm{~cm}$ long and $0.9-1$ $\mathrm{cm}$ wide, sometimes closely spaced and overlapping. Funiculus thick.

Number of specimens examined. 4. UF158265839 (Figure 13.3).

Discussion. Four specimens from the Warman clay pit were described by Herendeen (1992, figs. 10-14, p. 89). The seed shape and fruit structure suggest that they may be related to Caesalpinioideae.

\section{Genus ORMOSIA Jackson, 1811 Ormosia sp.}

(Figure 14.5-6)

Description. Fruits are pods, $2.5-3.7 \mathrm{~cm}$ long and $1.5-2.1 \mathrm{~cm}$ wide, bearing one to three transversely oriented seeds. Apex rounded to beaked, tapered base straight to curve. Fruit margin straight to slightly constricted between seeds. Sutures obvious; fruit dehiscent with valves not twisting.

Number of specimens examined. 8. 51357 (Figure 14.5); UF15826-5820 (Figure 14.6).

Discussion. Herendeen (1992, figs. 103-110, p. 106) described one species of fruit (eight specimens) and two species of leaflets (52 specimens) from the Warman clay pit.

Genus cf. SWARTZIA von Schreber, 1791

Swartzia sp.

(Figure 13.1)

Description. Fruits sessile pods, dehiscent with curling valves, $6.8-10.2 \mathrm{~cm}$ long and $1.9-2.7 \mathrm{~cm}$ wide. Outline of seeds or seed chambers not observed. Fruit apex and base acute and curved either in the same or opposite directions. Fruit outline also curved. Fruit valves not woody and sometimes with venation incompletely preserved. Placental suture narrowly flanged with sutures well developed.

Number of specimens examined. 5. UF158269041 (Figure 13.1).

Discussion. This is one of five specimens from the Warman and Lawrence clay pits described by Herendeen (1992, figs. 69-76, p. 104). Two types of Swartzia leaflets are also described from these two localities.

\section{"Thick walled fruit"}

(Figure 14.4)

Description. Fruits sessile with straight margins, $4.6-6.5 \mathrm{~cm}$ long and $2.2-2.3 \mathrm{~cm}$ wide with rounded apex and base, containing 5-8 transversely oriented seeds. Seed chambers well developed. Valves thick and woody. Sutures ca $2-4 \mathrm{~mm}$ thick 
with numerous parallel oblique striations. Fruit dehiscent with valves not twisting.

Number of specimens examined. 4. UF158265835 (Figure 14.4).

Discussion. The illustrated specimen is one of four from the Warman clay pit described by Herendeen (1992, figs. 239-242, p. 133). Although comparable to Ormosia, their affinities are uncertain due to the lack of diagnostic characters.

Order FAGALES Engler, 1892

Family FAGACEAE Dumortier, 1829

Genus QUERCUS Linnaeus, 1753

Quercus oligocenensis Daghlian and Crepet, 1983

(Figure 15)

Description. Catkin ca $1.5 \mathrm{~cm}$ long, containing at least 11 male florets, each ca $1.5-2 \mathrm{~mm}$ in diameter and $1 \mathrm{~mm}$ in length. In situ tricolpate pollen grains present.

Number of specimens examined. 2. UF1582651481 (Figure 15.1-2); 51384 (Figure 15.3).

Discussion. These two specimens are similar to the specimens from the Oligocene Huntsville locality, Texas, described by Daghlian et al. (1980, figs. 2, 3) and Daghlian and Crepet (1983, figs.1-13). The presence of this modern genus is based upon similarities of fossil catkins to and its co-occurrence with leaves assigned to the subgenus Erythrobalanus (Quercus catahoulaensis) and fossil fruits to the subgenus Lepidobalanus ( $Q$. huntsvillensis) (Daghlian et al., 1980; Daghlian and Crepet, 1983). Tricolpate in situ pollen grains are present on the florets of the specimens from the Warman clay pit. If further examination of the catkins reveals that they do belong to the same taxon, it would extend the age of the genus back to the middle Eocene.

\section{Fagaceous Fruit Type 1 \\ (Figure 16.1-2)}

Description. Fruit cupulate, spiny. Fruit body ca 1.5-3.5 cm in diameter. Spines simple or branched. Simple trichomes present on the spines. Number of specimens examined. 8. UF1582651476 (Figure 16.1-2).

Discussion. These specimens are the same as the castaneoid cupule from the Puryear clay pit, Tennessee (UF15820) illustrated by Crepet and Daghlian (1980, fig. 36). Staminate inflorescences, i.e., Castaneoidea puryearensis Crepet and Daghlian, co-occur at the Puryear clay pit. Their affinity with the modern subfamily Castaneoideae is corroborated based upon their co-occurrence and comparison of the floral and pollen morphology of C. puryearensis with extant Fagaceae.
This fruit type is similar to extant Castanea fruits (Figure 16.4) in having simple spines. It differs from Fagaceous Fruit Type 3 by the lack of web-like tissues and the absence of intertwined appendages.

Permineralized castaneoid fruits, Cascadiacarpa spinosa Mindell, Stockey et Beard, were reported from the Eocene of Vancouver Island, Canada (Mindell et al., 2007). These well-preserved fruits are most similar to extant Castanopsis species (Fagaceae) but differ in having only two locules. The compressed cupulate fruits from Warman clay pit and other localities in the southeastern United States are larger than C. spinosa . The spines of both fruits branch, but simple trichomes are present on the spines of the Warman specimens.

\section{Fagaceous Fruit Type 2}

(Figure 16.3)

Description. Fruit ca $2 \mathrm{~cm}$ long and $2 \mathrm{~cm}$ wide with simple unbranched spines up to $1.5 \mathrm{~cm}$ long and 2 mm wide.

Number of specimens examined. 1. UF1582651231 (Figure 16.3).

Discussion. Only the distal portion of a fruit is observed. This specimen appears to represent a cupulate spiny fruit. The simple spines are different from the branched spines on Fagaceous Fruit Type 1 (Figure 16.1-2) and Fagaceous Fruit Type 3 (Figure 17.1-4).

Fagaceous Fruit Type 3

(Figure 17)

Description. Fruit $1 \mathrm{~cm}$ to $2.5 \mathrm{~cm}$ in diameter. Basal portions of fruit appendages intertwined, forming a web-like pattern with laminal tissues within the network. Distal portions of the appendages spiny, simple or branched. Simple trichomes present on the spines and lamina tissue. Peduncle up to $1 \mathrm{~cm}$ long and $1 \mathrm{~mm}$ wide with scattered simple spines.

Number of specimens examined. 4. UF1582629216 (Figure 17.1-3); 51307 (Figure 17.4)

Discussion. The web-like structure from which the spines arise may represent a fruit wing. This major character distinguishes this fruit type from Fagaceous Fruit Type 1 (Figure 16.1-2) and Fagaceous Fruit Type 2 (Figure 16.3).

Family JUGLANDACEAE de Candolle ex Perleb, 1818

Genus EOKACHYRA Crepet, Dilcher and Potter, 1975 

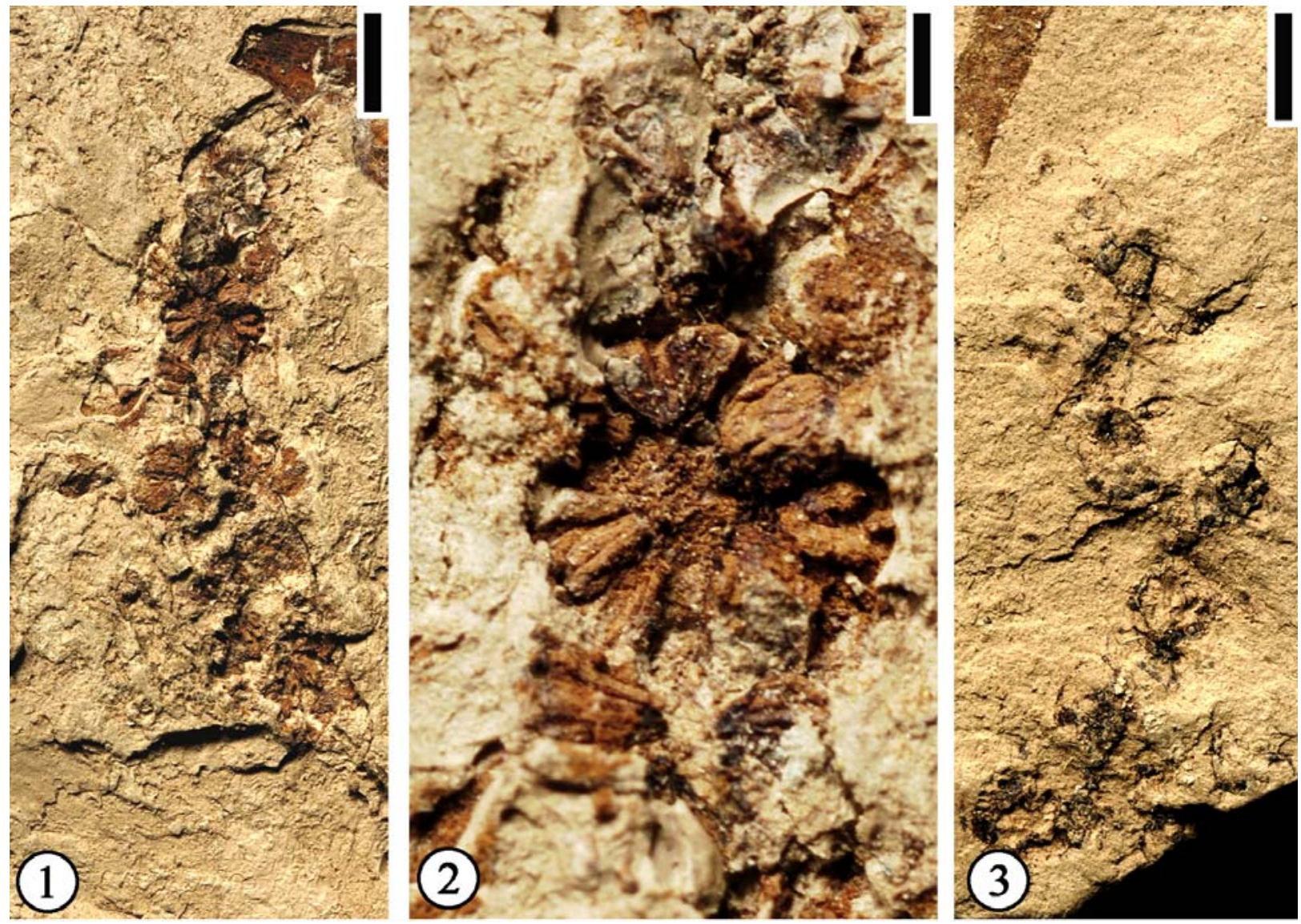

FIGURE 15. Quercus oligocenensis Daghlian and Crepet. 1. UF15826-51481. Showing an incomplete staminate catkin. Scale bar $=2 \mathrm{~mm}$. 2. Enlargement of Figure 15.1 to show a cluster of florets. Scale bar $=0.5 \mathrm{~mm}$.

3. UF15826-51384. Showing an incomplete catkin with at least 8 flower heads. Scale bar $=2 \mathrm{~mm}$.

Type species. Eokachyra aeolius Crepet, Dilcher and Potter, 1975

\section{Eokachyra aeolius Crepet, Dilcher and Potter, 1975}

(Figure 18)

Description. Staminate flowers helically arranged on axes. Flowers small, bilaterally symmetrical, and subtended by an elongate, three- to sometimes four-lobed bract. Floral envelope composed of three conspicuous, slightly concave, obovate perianth parts. Two perianth parts of the same size and lateral to a median, elongate, third perianth part extending beyond the subtending bract. Anthers 10 to 15 , borne on elongate floral receptacle.

Number of specimens examined. 17. UF1582633572 (Figure 18.1-2), 33573 (Figure 18.3-5), 33574 (Figure 18.6-7).

Discussion. Based upon floral, cuticular features, and pollen morphology, Crepet et al. (1975) placed three specimens described from the Warman clay pit in the fossil-genus within the Juglandaceae. Additional specimens observed demonstrate that the floral bract can vary from 3 to 4 lobes even on the same catkin (Figure 18.6-7), and that flowers of a catkin mature progressively from the proximal portion toward the distal end (Figure 18.1-2). Distal, immature flowers tend to be more crowded than mature ones on the proximal portion (Figure 18.1-2)

Genus PALEOOREOMUNNEA Dilcher, Potter, and Crepet, 1976

Type species. Paleooreomunnea stoneana Dilcher, Potter, and Crepet, 1976

\section{Paleooreomunnea stoneana Dilcher, Potter, and Crepet, 1976 \\ (Figure 19)}

Description. Winged nut bilobed, orbiculate, ca 12 $\mathrm{mm}$ high and $14 \mathrm{~mm}$ wide. Persistent sepals ca 2.0 $\mathrm{mm}$ long. Wing trilobed with shallow sinuses; each lobe with a primary vein and two slightly less con- 


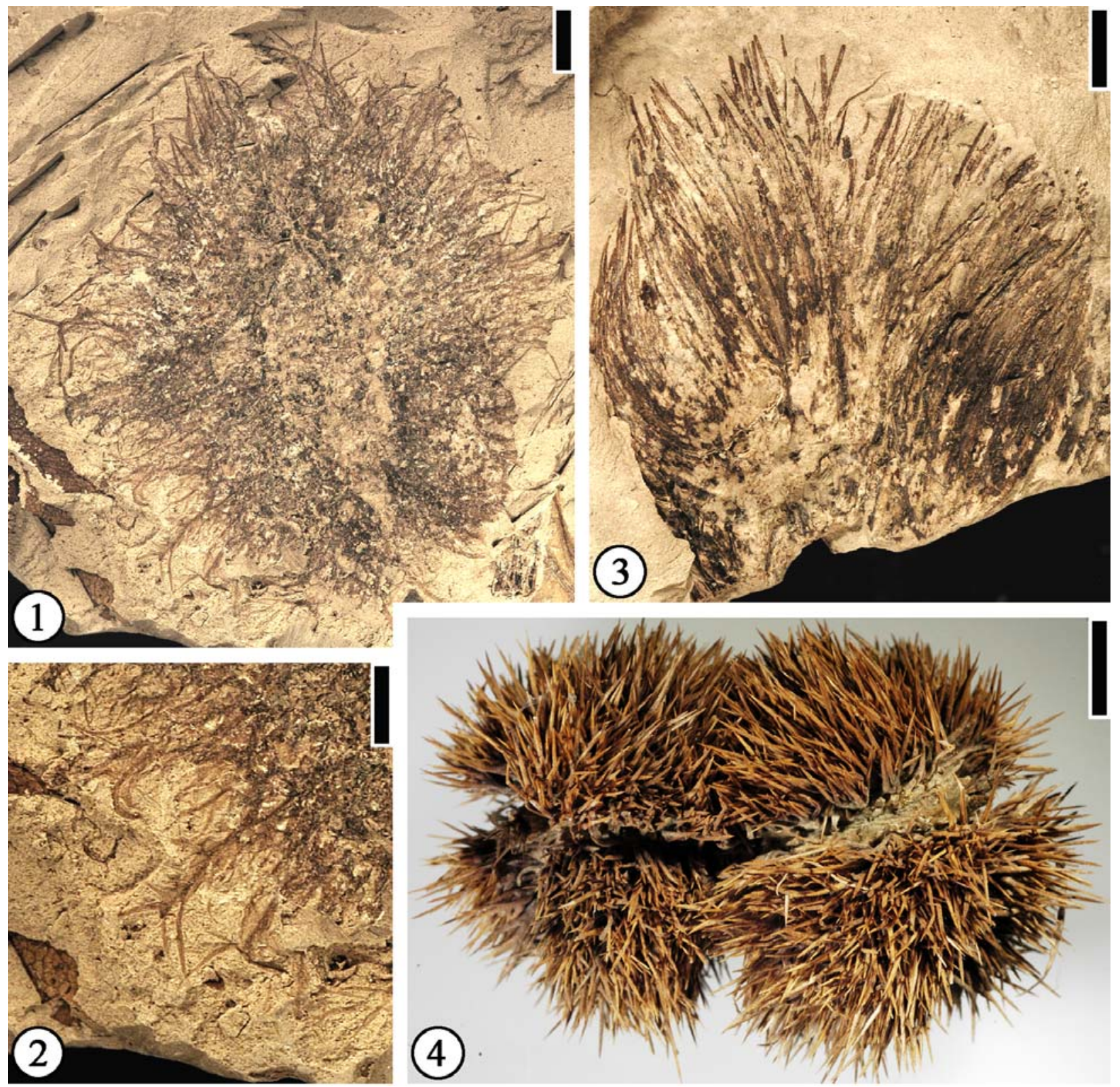

FIGURE 16. Fagaceous Fruit Type 1. 1. UF15826-51476. Simple and branched spines (appendages). Scale bar $=3$ $\mathrm{mm}$. 2. Enlargement of Figure 16.1 to show branched spines. Scale bar $=2 \mathrm{~mm}$. Fagaceous Fruit Type 2. 3. UF1582651231. Simple spines. Scale bar $=3 \mathrm{~mm}$. Castanea mollissima Blume. 4. UF1248. Extant fruit showing simple spines. Scale bar $=1 \mathrm{~cm}$.

spicuous lateral veins, one on each side; primary veins branching freely to form numerous secondary and tertiary veins that branch and anastomose further and form loops at the margin; areoles supplied with numerous freely ending veinlets; prophyllum rounded.

Number of specimens examined. 2. UF158261879 (Figure 19.1); 51510 (Figure 19.2).

Discussion. Dilcher et al. (1976; fig. 27) established the extinct genus and species based upon one specimen from the Warman clay pit, Tennessee and 8 specimens from the Lamkin clay pit Kentucky. Manchester (1987) described additional specimens and recognized freely ending veinlets in the fruit wing. Manchester (1987) recognizes the projection at the distal end of the nut as persistent sepals while Dilcher et al. (1976) recognize it as a stigma.

The wing is formed by a 3-lobed bract, which is characteristic of modern Engelhardia fruits, but 

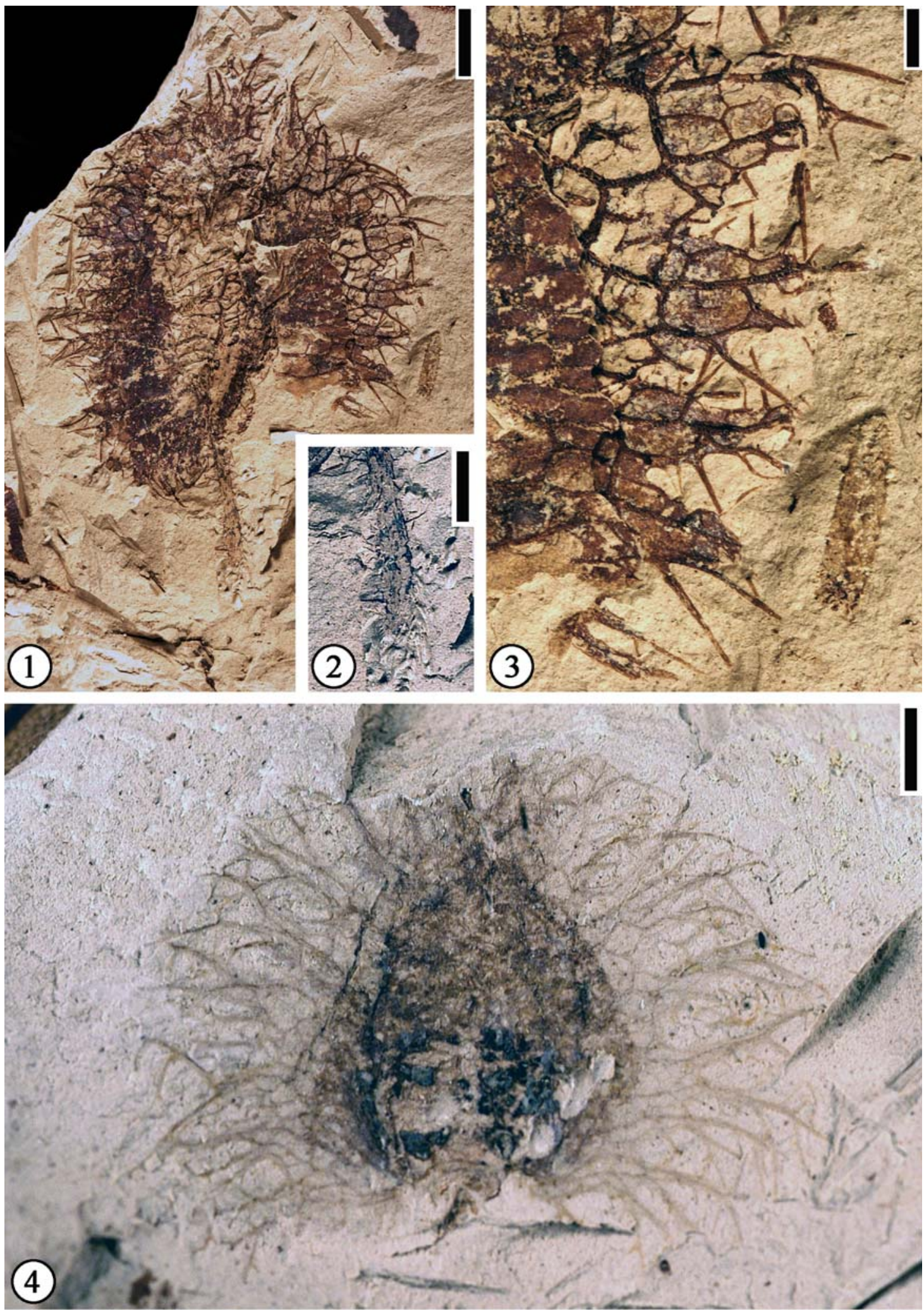

FIGURE 17. Fagaceous Fruit Type 3. 1. UF15826-29216. A long peduncle and thorn-like appendages. Scale bar $=4$ $\mathrm{mm}$. 2. Enlargement of Figure 17.1 to show the thorns on the peduncle. Scale bar $=2 \mathrm{~mm}$. 3. Enlargement of Figure 17.1 to show the web-like pattern of the appendages. Scale bar $=1 \mathrm{~mm}$. 4. UF15826-51307. A small fruit; note the intertwining spines. Scale bar $=1 \mathrm{~mm}$. 

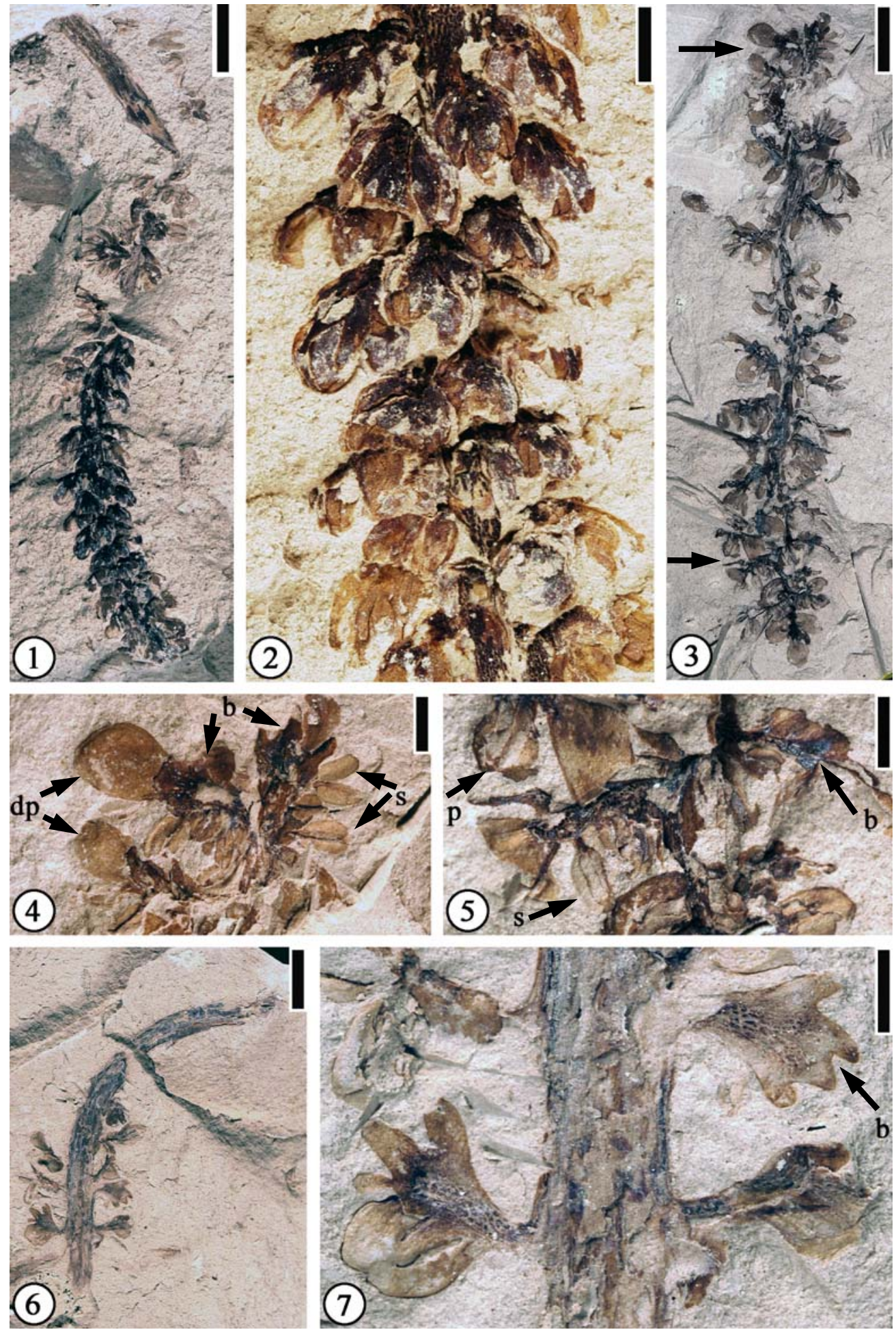

FIGURE 18. Eokachyra aeolius Crepet, Dilcher, and Potter. 1. UF15826-33572. A complete catkin with mature flowers on the proximal portion and immature flowers on the distal portion. Scale bar $=4 \mathrm{~mm}$. 2. Enlargement of Figure 18.1 to show helical arrangement of flowers. Scale bar $=1 \mathrm{~mm}$. 3. UF15826-33573. An incomplete mature catkin. Arrows indicate flowers enlarged in Figure 18.4, 5. Scale bar $=4 \mathrm{~mm}$. 4. Enlargement of flowers from Figure 18.3 (indicated by upper arrow) to show distal perianth (dp), bracts (b), and stamens (s). Scale bar $=1 \mathrm{~mm}$. 5 . Enlargement of flowers from Figure 18.3 (indicated by lower arrow) to show perianth (p), bracts (b), and stamens (s). Scale bar $=1 \mathrm{~mm}$. 6. UF15826-33574. An incomplete mature catkin with stamens shed. Scale bar $=4 \mathrm{~mm}$. 7. Enlargement of Figure 18.6 to show a four-lobed bract (b). Scale bar $=1 \mathrm{~mm}$. 

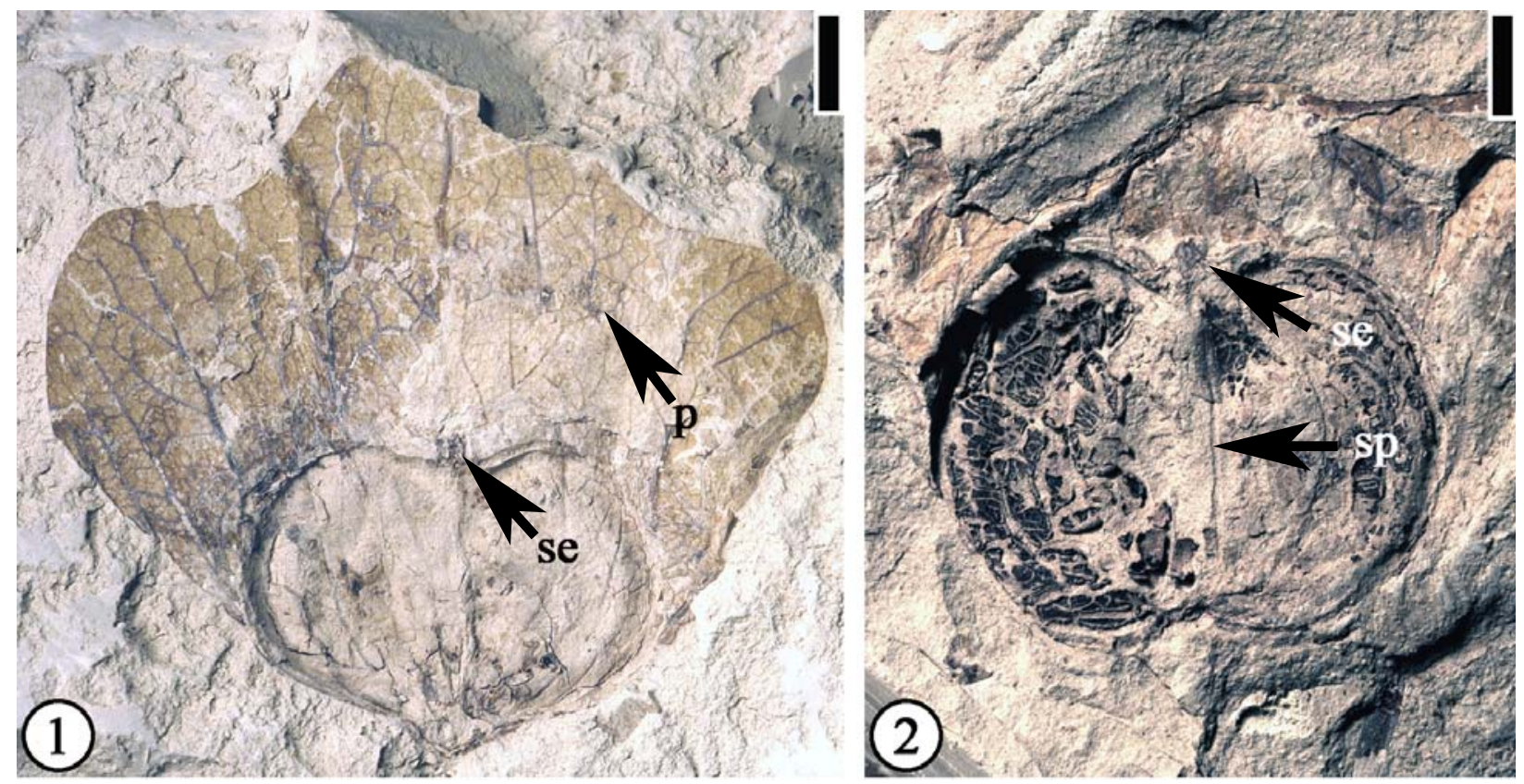

FIGURE 19. Paleooreomunnea stoneana Dilcher, Potter, and Crepet. 1. UF15826-1879. A bilobed nut and a tri-lobed wing with well-preserved venation. Note intact sepals (se), prophyllum (p). Scale bar $=5$ mm. 2. UF15826-51510. Intact sepals (se) and a prominent septum (sp) dividing the nut compression into two parts. Scale bar $=5 \mathrm{~mm}$.

the shallow sinuses between lobes are different from any of the modern genera.

Order MALPIGHIALES von Martius, 1835

Family EUPHORBIACEAE de Jussieu, 1789 Genus HIPPOMANEOIDEA Crepet and Daghlian, 1982

Type species. Hippomaneoidea warmanensis Crepet and Daghlian, 1982 (designated here)

Hippomaneoidea warmanensis Crepet and Daghlian, 1982

(Figure 20)

Description. Inflorescences spikes, occasionally branched, up to $5 \mathrm{~cm}$ long, consisting of bract-subtended cymules, each composed of at least three staminate florets with at least three stamens each. Bracts ovate and cupped. Pollen tricolporate and prolate with elongate pores.

Number of specimens examined. 1. UF1582651506 (Figure 20.1-3).

Discussion. Crepet and Daghlian (1982) described several specimens from the Warman clay pit. They established the genus, Hippomaneoidea, based upon similarity of the inflorescences and pollen grains to a complex of genera within the Hippomaneae. They did not designate a type species for this genus. Fossil fruits sharing features with the hippomanean genera Hippomane and Hura were also reported from the Claiborne Group (Manchester and Dilcher, 1979; Dilcher and Manchester, 1988).

Family MALPIGHIACEAE de Jussieu, 1789 Genus EOGLANDULOSA Taylor and Crepet, 1987

Type species. Eoglandulosa warmanensis Taylor and Crepet, 1987 (Designated here)

Eoglandulosa warmanensis Taylor and Crepet, 1987

(Figure 21)

Description. Vertically compressed flower ca $1 \mathrm{~cm}$ in diameter. Floral parts (sepals?) oblong or triangular with acute apices; slightly connate at the base, $4 \mathrm{~mm}$ long and $2 \mathrm{~mm}$ wide. Ovary $2 \mathrm{~mm}$ in diameter. Stamens $1 \mathrm{~mm}$ long and $0.5 \mathrm{~mm}$ wide, alternate with sepals. Sepals and ovary covered with simple trichomes.

Number of specimens examined. 1. UF1582633557 (Figure 21.1-2).

Discussion. Taylor and Crepet (1987, figs. 1-6, 9$13,33,34)$ described 11 compressed flowers from the Warman clay pit and established the genus and species, Eoglandulosa warmanensis. It has paired glands on the five sepals, clawed petals and tricolporate pollen with reticulate ornamentation and an unusual infratectal wall structure of anastomosing elements. The current specimen stored in the 

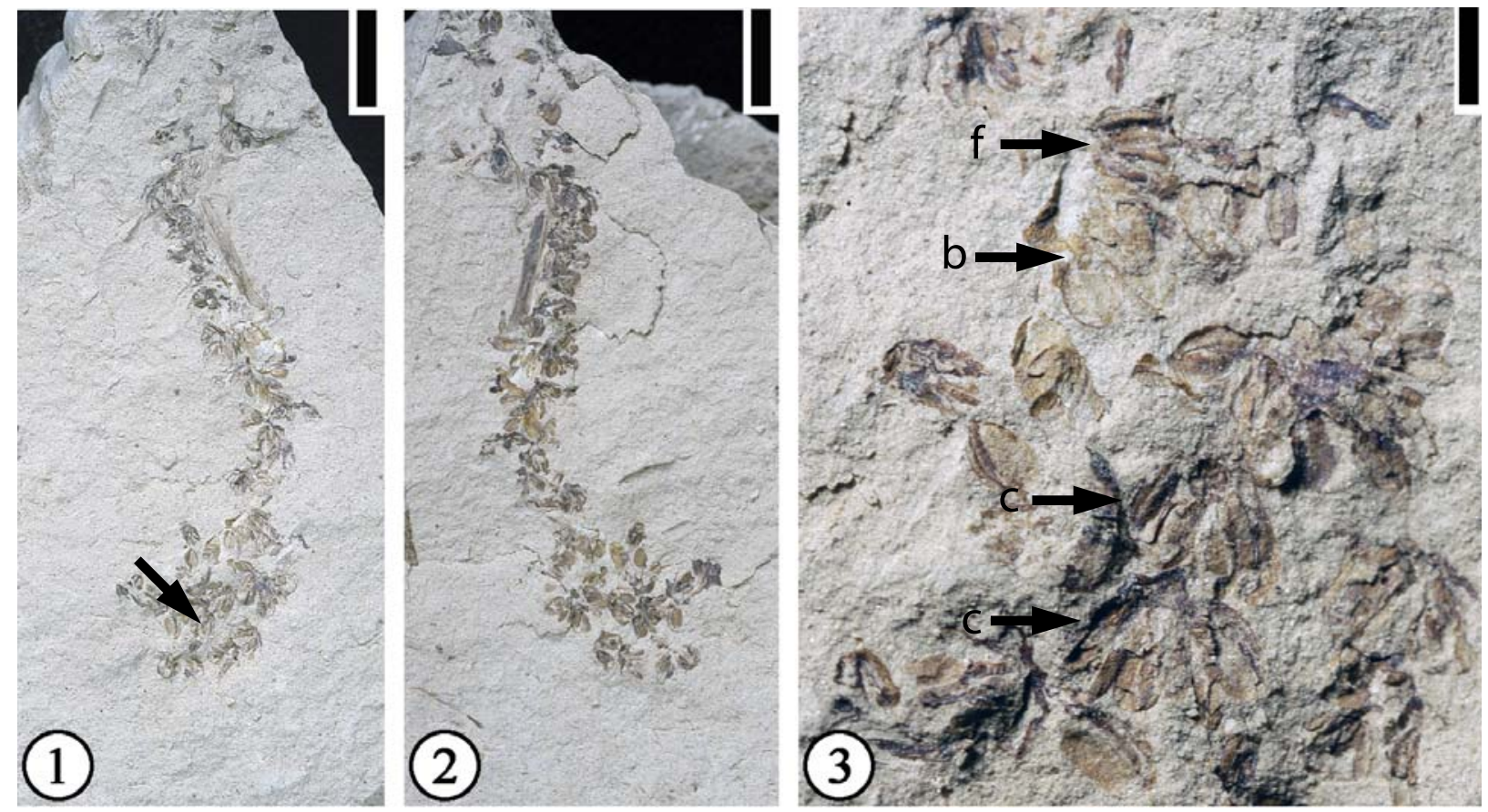

FIGURE 20. Hippomaneoidea warmanensis Crepet and Daghlian. 1. UF15826-51506. An incomplete inflorescence (arrow indicates floral parts enlarged in Figure 20.3). Scale bar $=5 \mathrm{~mm}$. 2. Counterpart of Figure 20. 1. Scale bar $=5$ $\mathrm{mm}$. 3. Enlargement of Figure 20.1 to show a dispersed floret (f), a bract (b), and two attached cymules (c). Scale bar $=1 \mathrm{~mm}$.
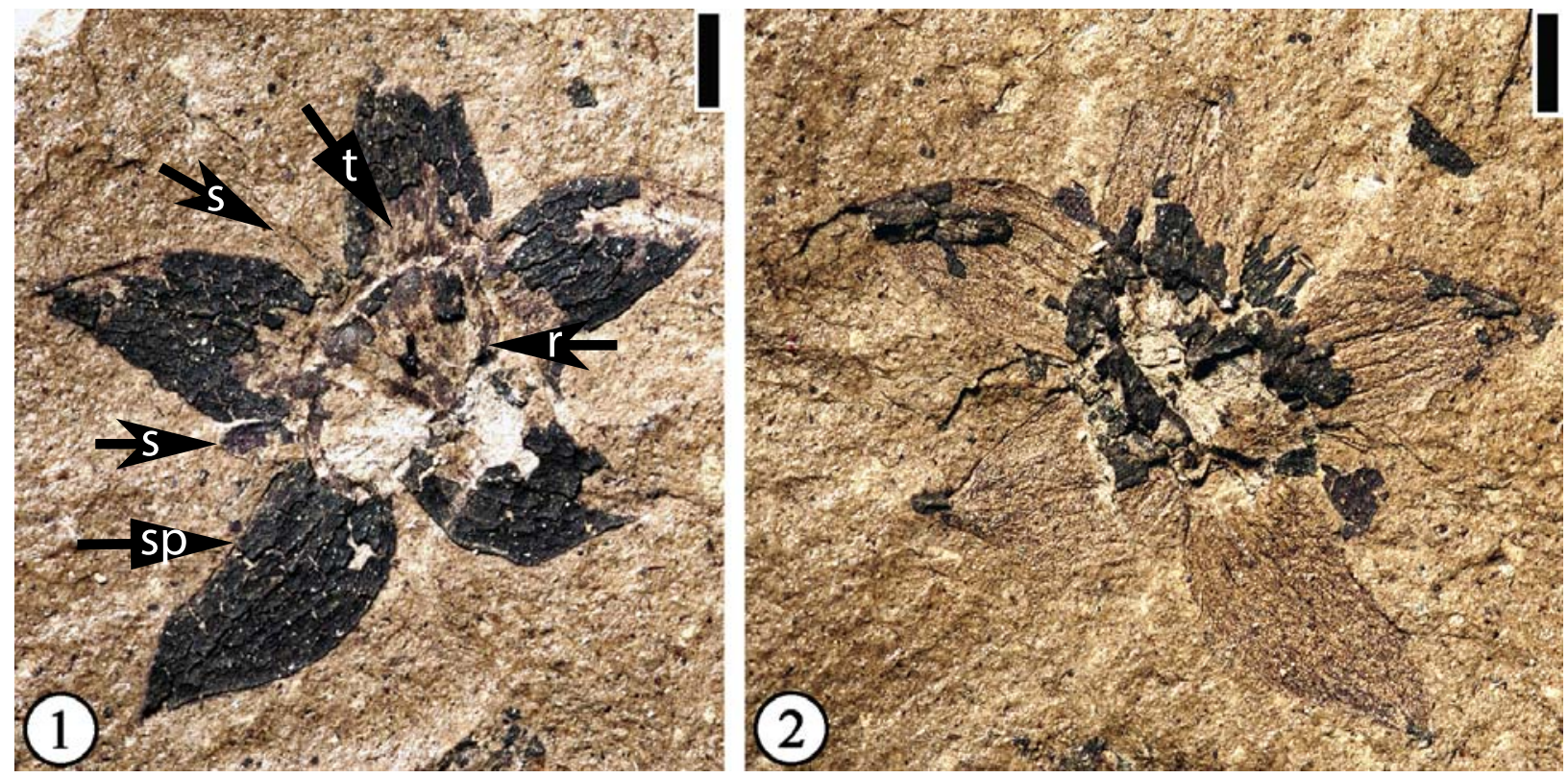

FIGURE 21. Eoglandulosa warmanensis Taylor and Crepet. 1. UF15826-33557. Showing a thickened circular rim (r), floral parts (sepals? - sp), stamens (s), and trichomes (t). Scale bar $=1 \mathrm{~mm}$. 2. Counterpart of Figure 21.1 showing venation of the sepals. Scale bar $=1 \mathrm{~mm}$. 
Paleobotany Collection at the Florida Museum of Natural History shows superficial similarity to Eoglandulosa warmanensis but the diagnostic paired, proximal, abaxial glands on the sepals are not observed.

Order ROSALES Perleb, 1826

cf. Family MORACEAE Link, 1831

Genus CORNEROCARPON Grote, gen. nov.

Generic diagnosis. Compound fruit (syncarp) consisting of a receptacle in which three to six fruitlets are embedded. Fruit obconic with an obliquely truncated upper part bearing fruitlets and a lower part bearing "tepals"; each fruitlet with a peripheral whorl of five bracts. Peduncle slender.

Derivation of the generic name. In honor of E. J. $\mathrm{H}$. Corner for his studies of Moraceae and his extensive work on recent seed anatomy.

Type species. - Cornerocarpon copiosum Grote

Cornerocarpon copiosum Grote sp. nov.

(Figures 22, 23)

1930 Sterculiocarpus sphericus Berry, p. 109, pl. 48, fig. 11.

Specific diagnosis. Same as for the genus.

Description. Compound fruit consisting of a receptacle in which (3)4-6(7) fruitlets are embedded. Fruit obconic with an obliquely truncated, slightly convex upper part in which the fruitlets are embedded. Approximately an even number of specimens compressed laterally vs "ventrodorsally", considering the fruitlet-bearing surface to be ventral. Other specimens compressed in various other positions. "Ventrodorsally" compressed specimens 11.5-$28.8 \mathrm{~mm}$ in length and $8.5-21.2 \mathrm{~mm}$ in width. Laterally compressed specimens $11.6-33.2 \mathrm{~mm}$ in length and 8.0-22.8 mm in width. Short and slender peduncle subtending the receptacle. Five peripheral and separate bracts surrounding each fruitlet. Bracts rounded with a middle ridge and decurrent margins, 2.4-6.9 mm wide, although most bracts broken near the base. Surface of each fruitlet forming a flattened cone. Five, persistent, thickened rectangular "tepals" arising from the lower part of the receptacle; each "tepal' 2.2-5.0 $\mathrm{mm}$ wide and up to ca $6 \mathrm{~mm}$ long. Surface of the receptacle consisting of small, polygonal to rectangular cells.

Holotype. Designated here. UF15826-51278 (Figure 22.1, 22.3).

Additional specimens. UF15826-9198 (Figure 22.2); UF15815-9100 (Figure 23.1), UF158159101 (Figure 23.2).

Number of specimens examined. Five from Warman clay pit and three from Miller clay pit
(UF15817), Tennessee, 200 from Lamkin clay pit (UF15815), and four from Bell City clay pit (UF15803), Kentucky.

Derivation of species epithet. Latin for abundant. Discussion. A survey of the fruit types found in angiosperms by Grote (1989) showed only Moraceae and Cyclanthaceae to have compound fruits with individual fruitlets embedded in the fleshy receptacle. The infructescences of Cyclanthaceae are derived from a densely crowded spadix and are thus different from the fruit type of Cornerocarpon. Grote (1989) suggested that Cornerocarpon appears to have affinity to Moraceae, particularly the tribe Olmedeae and the genus Naucleopsis. Each fruitlet appears to contain one elongate seed. The point of attachment, the orientation, and the vascularization of the seed were not determined because of the compressed and partly fused nature of the specimens.

Order ERICALES Dumortier, 1829

Family THEACEAE D. Don, 1825

Genus GORDONIA J. Ellis, 1771

Gordonia warmanensis Grote and Dilcher, 1992

(Figure 24)

Description. Capsule elliptic, ca $2.8 \mathrm{~cm}$ long and $1.1-1.3 \mathrm{~cm}$ wide. Thin longitudinal striations present on the surface. Four or five valves distally dehiscent. Oil glands abundant on the inner walls of the capsule (Figure 24.3,5). Receptacle ca 5 $\mathrm{mm}$ long and $4 \mathrm{~mm}$ wide, with traces of sepals/petals. Seed ca $8 \mathrm{~mm}$ long and $3 \mathrm{~mm}$ wide; seed body triangular, ca $3 \mathrm{~mm}$ long and $1.7 \mathrm{~mm}$ wide.

Number of specimens examined. $>10$. UF15826-9526 (Figure 24.1); 52463 (Figure 24.2); 51292 (Figure 24.3, 5); 51412 (Figure 24.4, 6).

Discussion. Grote and Dilcher (1992) described 12 specimens from the Warman clay pit. These specimens include nine well-preserved capsules and two dispersed seeds. One specimen (Figure $24.4,6)$ shows four beaks at the distal end of the fruit and a longitudinal line of dehiscence extending about half the length of the fruit. The other specimen shows an incomplete pedicel ca $6 \mathrm{~mm}$ long and $2 \mathrm{~mm}$ wide. We illustrate four new specimens representing immature capsule, dehiscent capsule, and seeds.

\section{cf. Gordonia sp. 1}

(Figure 25)

Description. A vertically preserved flower showing pedicel, receptacle and two perianth parts (sepals?). Pedicel ca $4 \mathrm{~mm}$ in diameter. Receptacle $12.5 \mathrm{~mm}$ in diameter with numerous indenta- 


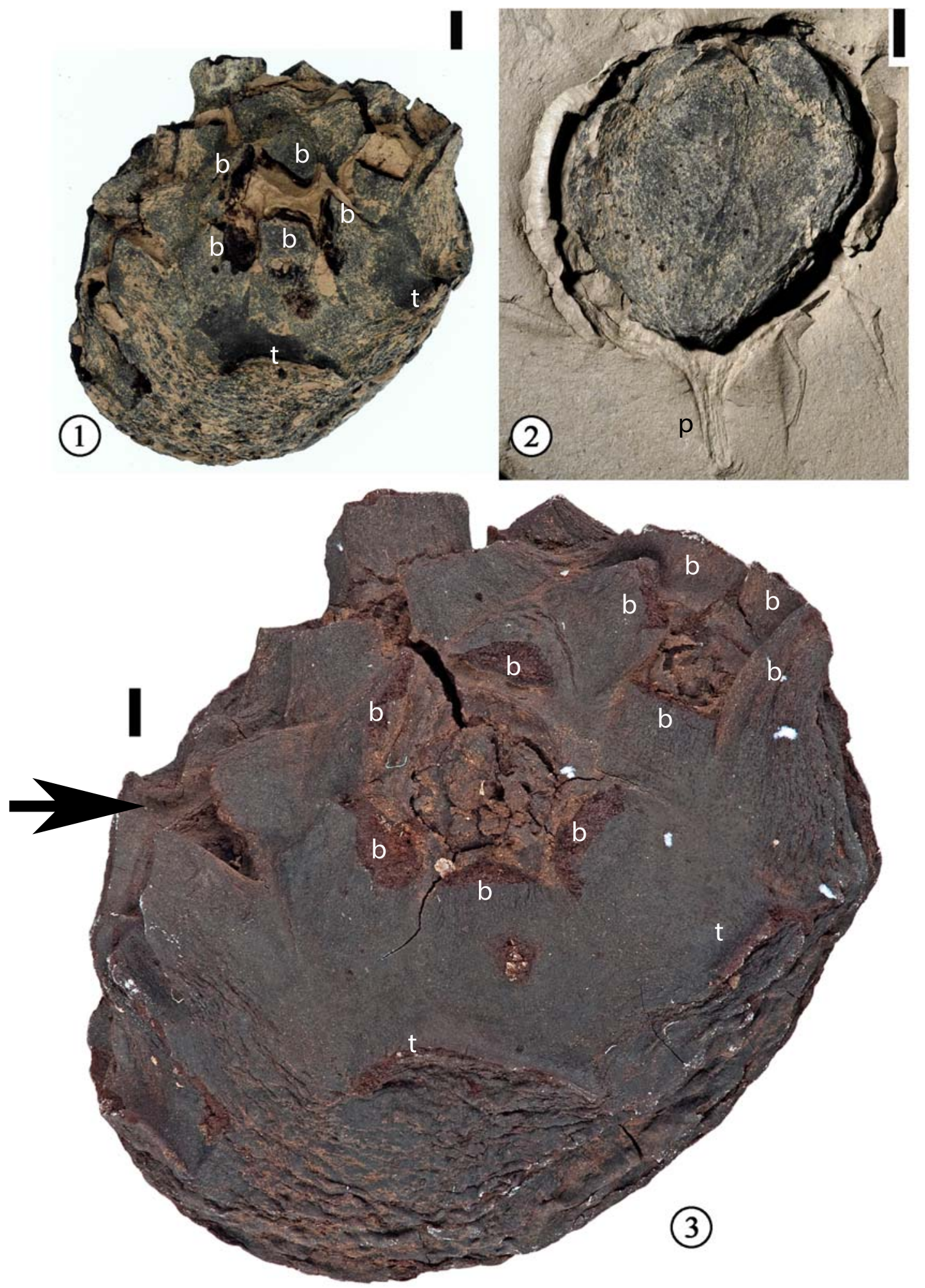

FIGURE 22. Cornerocarpon copiosum Grote gen. et sp. nov. 1. UF15826-51278. Showing the syncarp with "tepals" (t) and embedded fruitlets. A ring of five bracts (b) encircles each fruitlet. Scale bar $=2 \mathrm{~mm}$. 2. UF15826-9198. A compressed specimen showing the proximal side of the syncarp and the peduncle (p). Scale bar $=3 \mathrm{~mm}$. 3 . Same specimen as Figure 22.1 cleaned with HF and enlarged to show at least three embeded fruitlets, their bracts (b), and "tepals" ( $\mathrm{t}$ ). Each fruitlet has a ring of five bracts (b). The third fruitlet is indicated by the arrow. Scale bar $=1 \mathrm{~mm}$. 


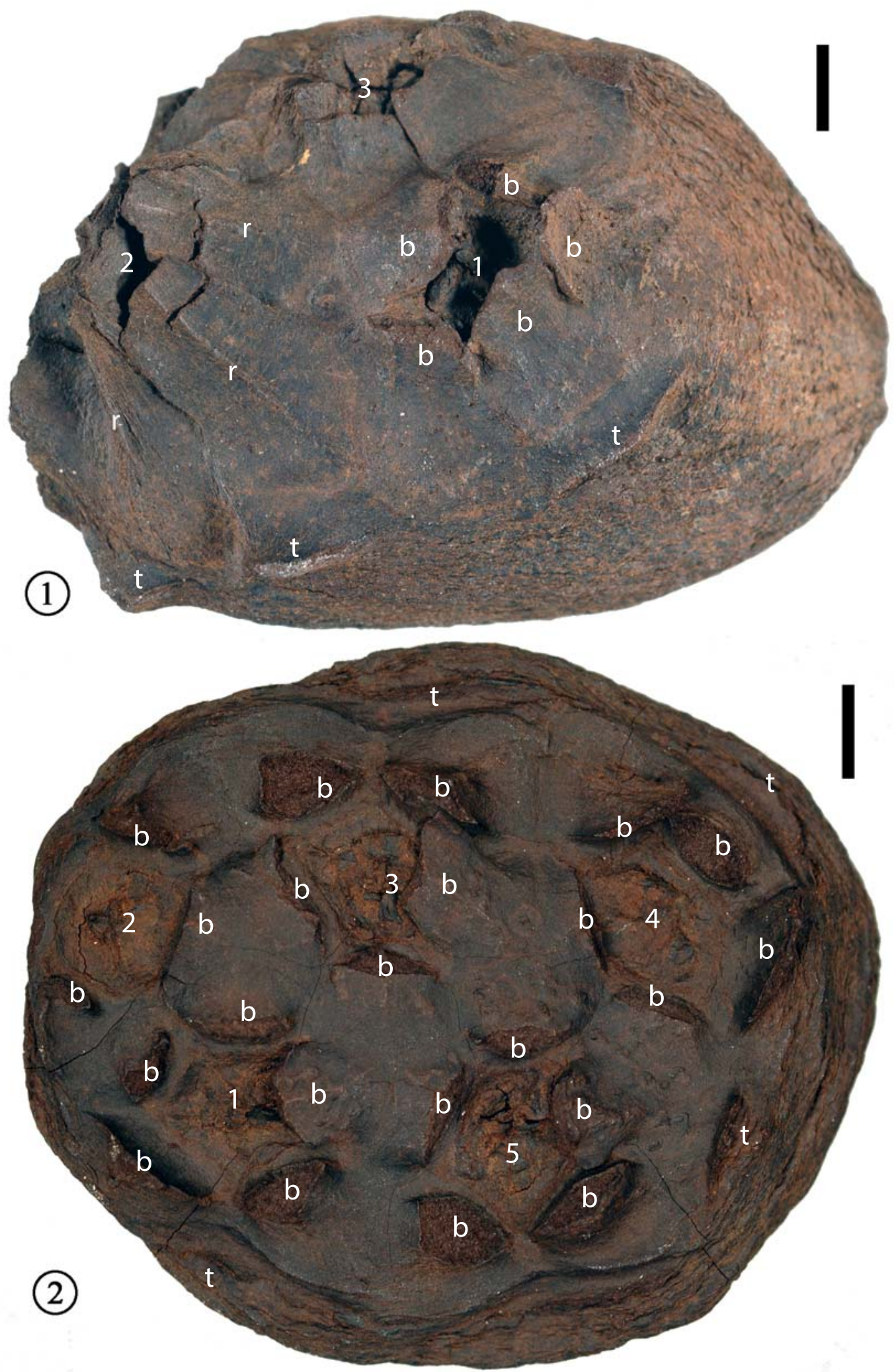

FIGURE 23. Cornerocarpon copiosum Grote gen. et sp. nov. Scale bars $=2 \mathrm{~mm}$. 1. UF15815-9100. A laterally compressed specimen showing three (indicated by numbers) fruitlets. Note the five bracts of fruitlet 1 , the ridges ( $r$ ) on the bracts of fruit 2, and the tepals (t). 2. UF15815-9101. A vertically compressed specimen showing five fruitlets (indicated by numbers), their bracts (b), and the tepals (t). 

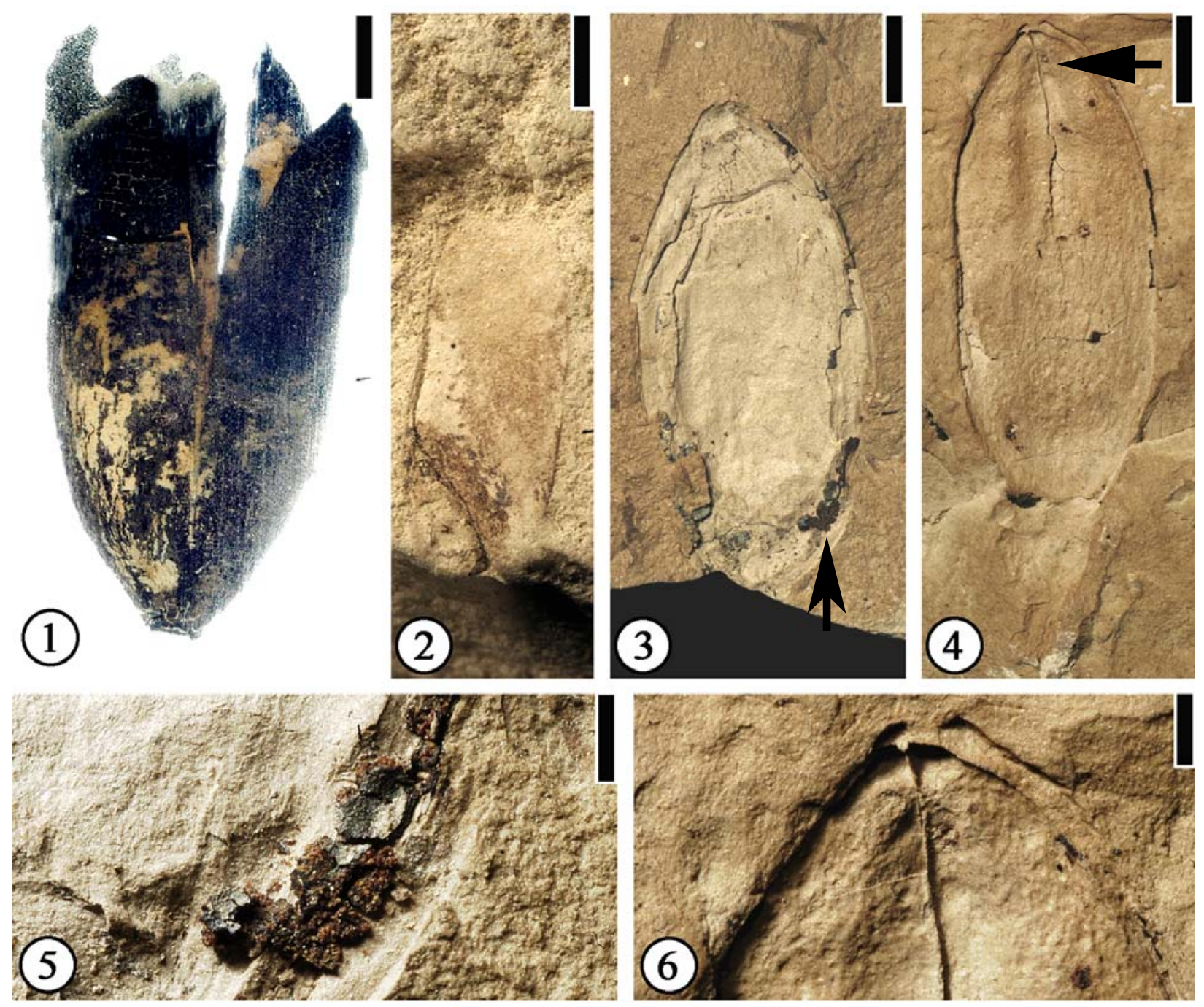

FIGURE 24. Gordonia warmanensis Grote and Dilcher 1992. 1. UF15826-9526. A three-dimensionally preserved five-valved, loculicidally dehiscent capsule. Scale bar $=4 \mathrm{~mm}$. 2. UF15626-52463. A compressed seed. Scale bar $=2$ mm. 3. UF15826-51292. A laterally compressed immature capsule. Scale bar $=5 \mathrm{~mm}$. 4. UF15826-51412. A laterally compressed capsule showing a loculicidal dehiscence line (indicated by arrow). Scale bar $=5 \mathrm{~mm}$. 5 . Enlargement of the base of the capsule in Figure 24.3 to show oil glands. Scale bar $=1 \mathrm{~mm}$. 6 . Enlargement of the apex of the capsule in Figure 24.4 to show four-valved capsule and a dehiscence line. Scale bar $=1 \mathrm{~mm}$.

tions. Perianth parts incomplete, separate, $1 \mathrm{~cm}$ wide and up to $1.8 \mathrm{~cm}$ long.

Number of specimens examined. 1. UF1582651541 (Figure 25).

Discussion. The flower has two perianth parts (possibly sepals) attached. Their basal width and their attachments on the pedicel indicate that five sepals are present. A similar flower was reported by Dilcher and Lott $(2005$, p. 17 , fig. 18, C, I) from the Puryear clay pit, Tennessee.

\section{cf. Gordonia sp. 2.}

(Figure 26)
Description. Laterally compressed flower buds ca $2.5 \mathrm{~cm}$ long and $1.8 \mathrm{~cm}$ wide, attached to a pedicel 4-5 mm in width. Five sepals present and enclosing other parts of the flower. Bract scars present on pedicels.

Number of specimens examined. 2. UF1582651405 (Figure 26.1-2); 33566 (Figure 26.3-4).

Discussion. These laterally compressed flower buds have five sepals and they probably represent the early stages of the flower. One specimen has an apical protrusion of ca $3 \mathrm{~mm}$ (Figure 26.3-4).

Genus ANDREWSIOCARPON Grote and Dilcher, 1989 


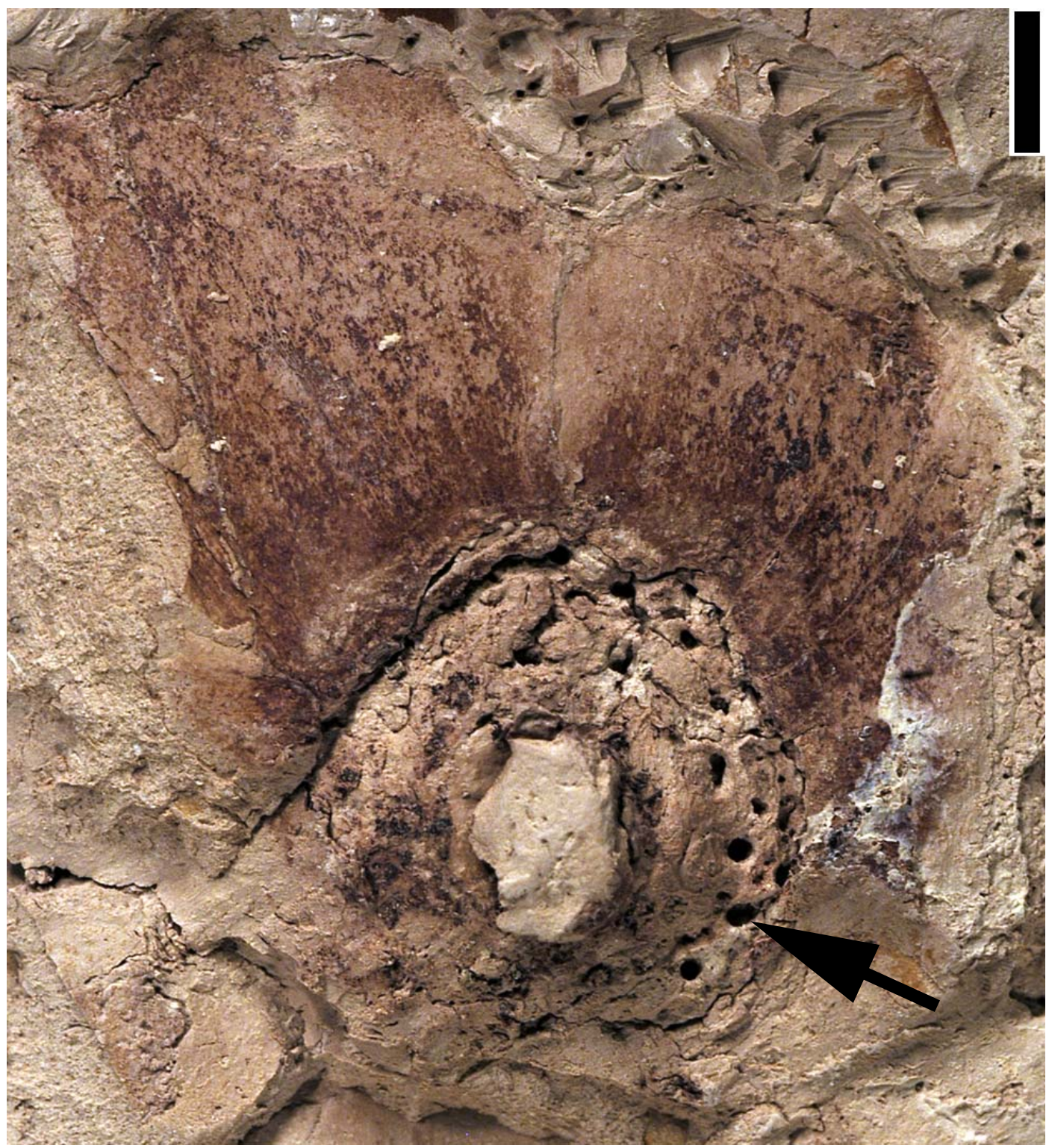

FIGURE 25. cf. Gordonia sp. 1. UF15826-51541. Impression of the base of a flower showing stamen bases (indicated by arrow) and two broken petals. Scale bar $=3 \mathrm{~mm}$.

\section{Andrewsiocarpon henryense Grote and Dilcher, 1989}

(Figure 27)

Description. Compressed capsules five-parted and loculicidally dehiscent. Lines of dehiscence extending from the apex to about $3 / 4$ of the capsule length. Five persistent sepals subtending the capsule. Vertically compressed capsules ca $2 \mathrm{~cm}$ in diameter. Laterally compressed capsules ca 1.5 $\mathrm{cm}$ long and $2 \mathrm{~cm}$ wide.

Number of specimens examined. $>10$ from Warman clay pit. UF15826-51407 (Figure 27.1-2); 51406 (Figure 27.3-4); 51499.
Discussion. More than 600 specimens of Andrewsiocarpon henryense Grote and Dilcher have been collected from 8 localities from Tennessee and Kentucky and were reported by Grote (1989) and Grote and Dilcher (1989). These specimens represent a new report of this species from the Warman clay pit.

Order LAMIALES Bromhead, 1838

Family BIGNONIACEAE de Jussieu, 1789 Genus GROTEA gen. nov.

Etymology. The genus name is named for Paul Grote, who studied many fossil fruits and seeds 

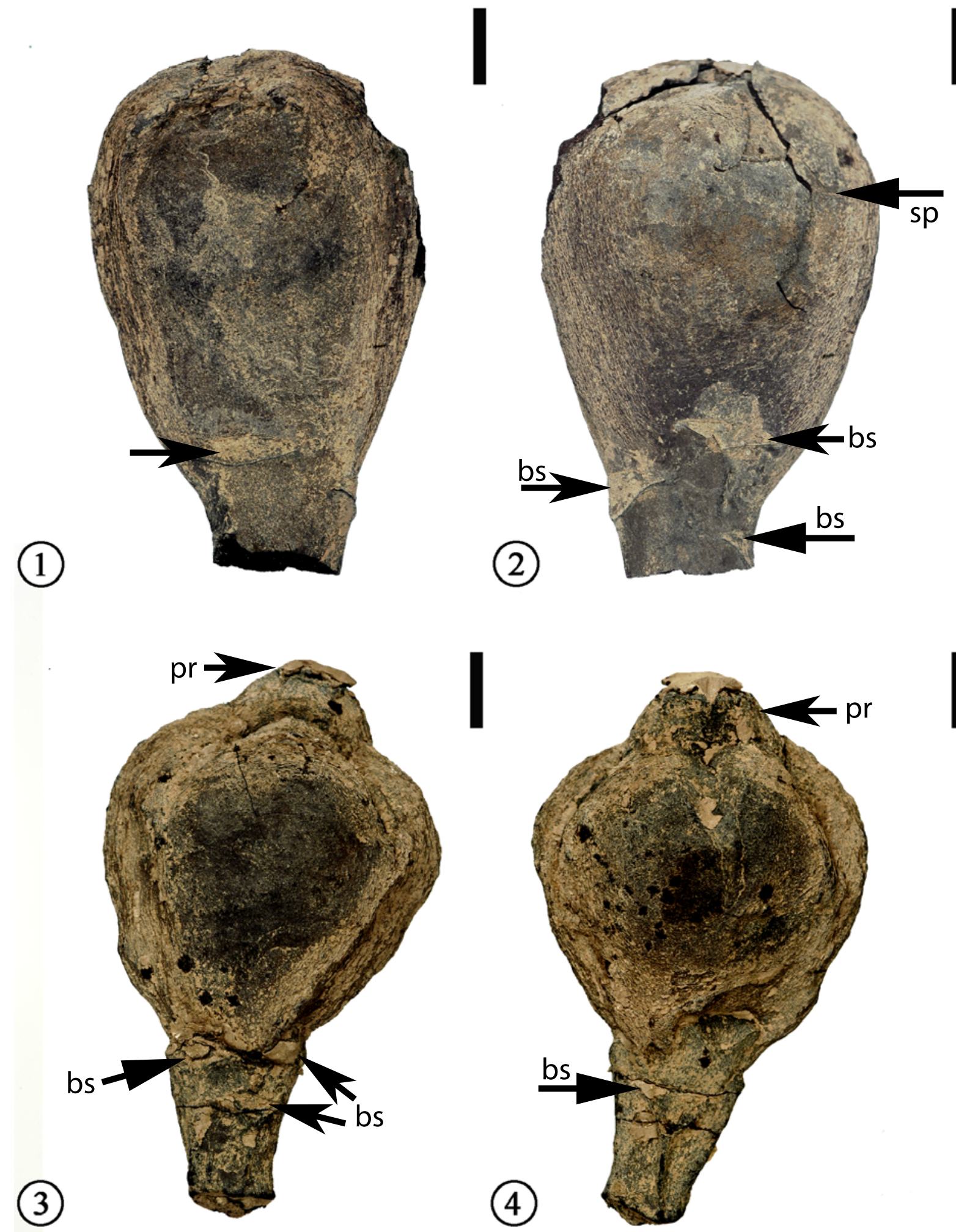

FIGURE 26. Gordonia sp. 2. 1. UF15826-51405. A laterally compressed flower bud showing no dehiscence. Arrow indicates a bracteole scar. Scale bar $=4 \mathrm{~mm}$. 2. Opposite side of Figure 26.1 showing bracteole scars (bs) and sepal (sp). Scale bar $=4 \mathrm{~mm}$. 3. UF15826-33566. A laterally compressed flower bud showing an apical protrusion (pr) and bracteole scars (bs). Scale bar $=4 \mathrm{~mm}$. 4. Opposite side of Figure 26.3 showing an apical protrusion (pr) and a bracteole scar (bs). Scale bar $=4 \mathrm{~mm}$. 
from the Claiborne Group of southeastern Unites States.

Diagnosis. Winged seed circular in outline, consisting of a central seed surrounded by a circular wing with fine veins.

\section{Grotea warmanensis sp. nov.}

(Figure 28.1)

Diagnosis. Same as for the genus.

Description. Winged seed circular, $2 \mathrm{~cm}$ in diameter, consisting of a central seed $1.5 \mathrm{~cm}$ long and $1.6 \mathrm{~cm}$ wide and a circular wing ca $7 \mathrm{~mm}$ wide encircling the seed except at the base. Apical portion of seed emarginate. Seed testa 1.5-1.8 mm wide. Fine radiating fiber strands present on the wing. Rahpe ca $1.2 \mathrm{~cm}$ long and $1 \mathrm{~mm}$ wide. Hilum scar $2 \mathrm{~mm}$ in diameter.

Species epithet. Referring to the occurrence of this species at the Warman clay pit locality, Tennessee.

Holotype. Designated here. UF15826-51212 (Figure 28.1).

Number of specimens examined. 2. UF1582651212 (Figure 28.1); 51213.

Discussion. In gross morphology, this specimen is similar to the fin-winged fruits of Dodonaea knowltoni described by Berry (1916) (plate LXIV, fig. 3). Berry (1916) placed this winged 2-celled fruit in the Sapindaceae and Manchester et al. (2009) recently transferred it to a modern genus Pteroceltis in the Cannabaceae. The new species differs from Pteroceltis knowltoni (Berry) Manchester, Chen, Lu and Uemura in having a larger fruit/seed size and a thin circular wing instead of two wings.

The new species differs from many fin-winged fruits (see Manchester and O'Leary, 2010) in having a thin circular wing with fine venation that radiates from the seed body and a thick seed testa.

The seed morphology of the new species resembles some members of the Bignoniaceae (i.e., Oroxylum and Pithecoctenium, Figure 28.2-3) in having a thin circular wing with fine venation but they differ in that the seed from Warman clay pit has a thick seed testa. Fossil fruits and seeds of Bignoniaceae have been reported from the late Early Eocene of Washington State (Wehr and Hopkins, 1994; Pigg and Wehr, 2002).

Family OLEACEAE Hoffmannsegg and Link, 1809 Genus FRAXINUS Linnaeus, 1753

Fraxinus wilcoxiana (Berry) Call and Dilcher, 1992 (Figure 29)

Description. Oblanceolate samaras consisting of a striate fruit body surrounded by an entire-margined wing. Fruit body slender, 17.0-18.0 mm long and $4.5-5.5 \mathrm{~mm}$ at its widest point, tapering to ca $1.0 \mathrm{~mm}$ at the base. Eight to 10 veins diverging towards the apex. Fruit wing widest at the apex of the fruit body (ca $7.0-8.0 \mathrm{~mm}$ ) and extending ca $4.0-5.0 \mathrm{~mm}$ beyond it to a broadly rounded apex. Fruit wing tapering to the base of the fruit or along its apical 2/3. Midrib on fruit wing not evident. Persistent calyx subtending the samara, lobed with acute apex; short peduncle present, $1-3 \mathrm{~mm}$ long and $1 \mathrm{~mm}$ wide (Figure 29.1).

Number of specimens examined. 3. UF158261368 (Figure 29.1); 1369 (Figure 29.2).

Discussion. Call and Dilcher (1992) described three specimens from the Warman clay pit and numerous specimens from the Puryear clay pit. We illustrate and re-describe two specimens from the Warman clay pit to show the occurrence of this species at this locality. The fruits are derived from a superior ovary. These fruits are assigned to the extant genus based upon the following combination of characters: (1) flattened, bilaterally symmetrical, single-seeded samara derived from a superior ovary; (2) fruit body longitudinally striated with a decussate, apically extended wing; (3) basal, persistent tetramerous calyx; and (4) striated cuticle bearing two distinct classes of peltate trichomes (Call and Dilcher, 1992).

Order APIALES Nakai, 1930

Family ARALIACEAE de Jussieu, 1789

Genus ARALIA Linnaeus, 1753

"Aralia" semina Berry, 1930

(Figure 30)

1930 Aralia? semina Berry, 1930, plate 8, figs. 2, 3, p. 124.

Description. Seeds elliptic to wide elliptic, 2.5-4.5 $\mathrm{mm}$ long and $1.5-2.5 \mathrm{~mm}$ wide with 14 to 16 longitudinal striations converging at the base (hilum?) and apex. Fine cross striations present between longitudinal striations.

Number of specimens examined. Thirty-six seeds on 10 specimens. UF15826-51298 (Figure 30.1); 51303 (Figure 30.6); 51477a (Figure 30.2), 51477b (Figure 30.3); 51483 (Figure 30.7-8); 51485 (Figure 30.4); 51550 (Figure 30.5).

Discussion. One specimen displays a cluster (1 $\mathrm{cm}$ long and $0.7 \mathrm{~cm}$ wide) with least 10 seeds (Figure 30.1). The cluster may represent a degraded fruit. Berry (1930) illustrated one seed and reported that this type of seeds is abundant in the Holly Springs sand at Bell City, Kentucky. He also noted that the characters of the seeds are not sufficient to establish their affinity with certainty and therefore the genus should be regarded as a fossil-genus. However, Dendropanax and other Araliaceous 

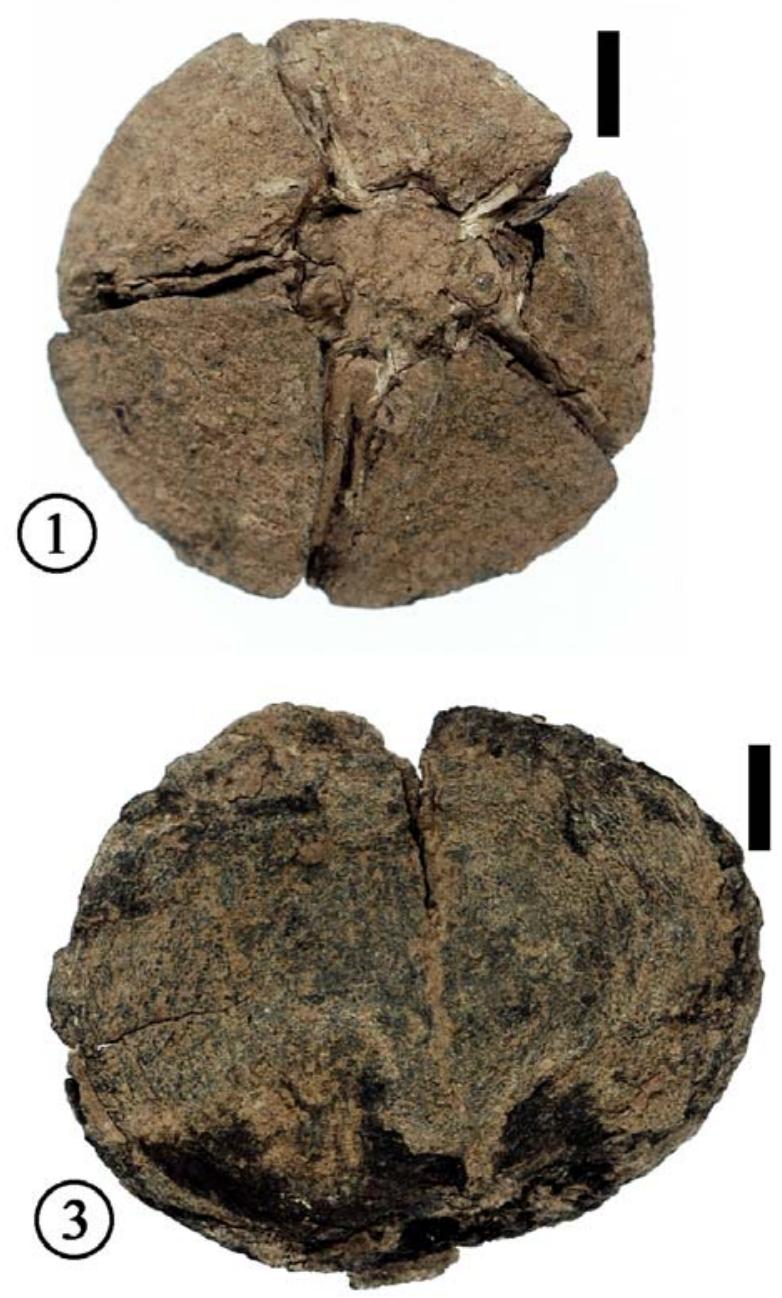
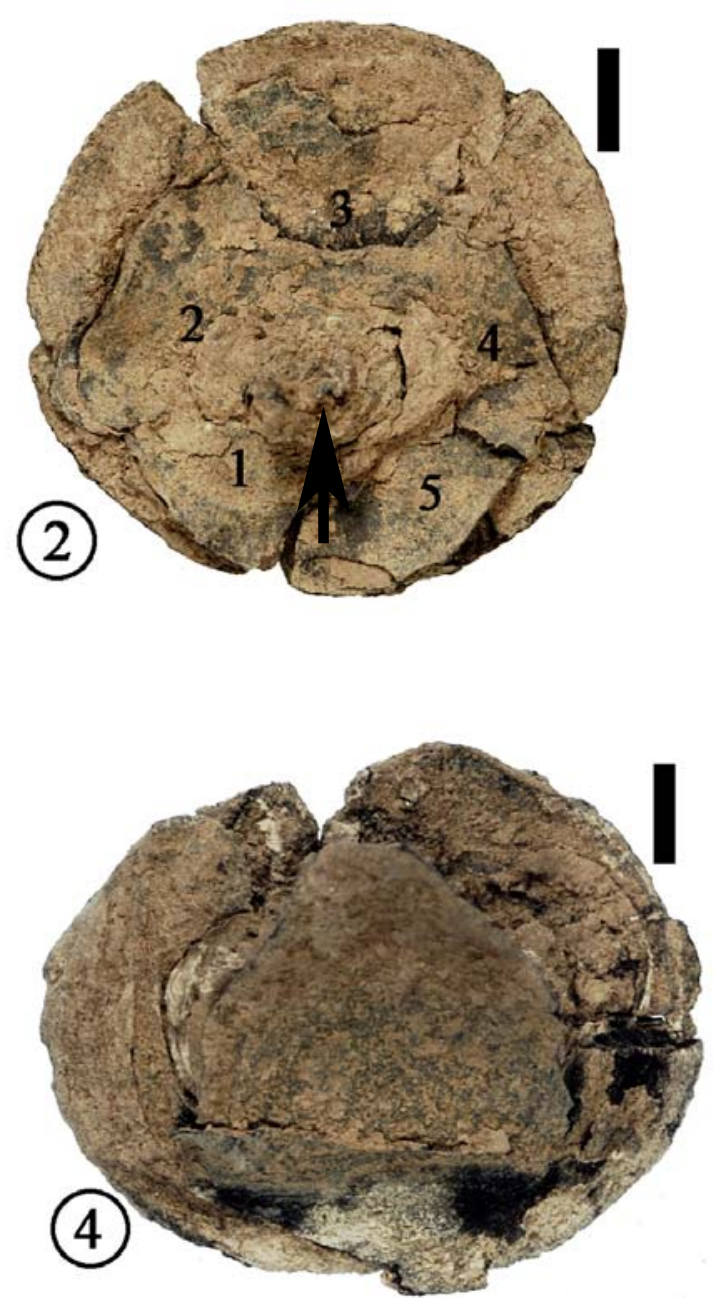

FIGURE 27. Andrewsiocarpon henryense Grote and Dilcher. All scale bars equal 3 mm. 1. UF15826-51407. Top view of a vertically compressed capsule showing loculicidal dehiscence. Scale bar $=3 \mathrm{~mm}$. 2. Opposite side of Figure 27.1 (bottom view) of a vertically compressed capsule showing 5 persistent sepals (indicated by numbers) and pedicel (indicated by arrow). Scale bar $=3 \mathrm{~mm}$. 3. UF15826-51406. A laterally compressed capsule. Scale bar $=2 \mathrm{~mm}$. 4 . Opposite side of Figure 27.3 showing dehiscence lines extending about $3 / 4$ of capsule length. Scale bar $=2 \mathrm{~mm}$.

leaves have been reported from several Eocene localities in Kentucky and Tennessee (Dilcher and Dolph, 1970; Dilcher and Lott, 2005). Araliaceous pollen has been reported from the Cockfield Formation of Mississippi (Engelhardt, 1964). The gross morphology of the fossils is similar to the seeds of some extant members (e.g., Aralia and Dendropanax) of the Araliaceae. It is reasonable to assume that these seeds are related to this family. However, more characters are needed to assign these seeds to any extant genera within the family.

In gross morphology, these seeds are similar to the arecaceous seeds described by Grote (1989, p.172-176; plate VII, figures 1-8) from the Lamkin clay pit, Kentucky (UF15815) in having similar size and longitudinal ridges. However, seeds from the Lamkin clay pit do not have fine cross striations between longitudinal ridges and we do not know if the longitudinal ridges on the Warman seeds are impressions of large fiber strands.

In gross morphology, these seeds are also similar to Palaeoaldrovanda splendens Knobloch and Mai from the mid-Cretaceous (Cenomanian) of central Bohemia (Knobloch and Mai, 1984; 1986; 1991) and from the Eocene of Messel Germany (Spirellea sp., S. R. Manchester, personal communication). The Warman seeds vary from 2.5-4.5 $\mathrm{mm}$ long and $1.5-2.5 \mathrm{~mm}$ wide but the size of the central Bohemia seeds is usually less than $2.4 \mathrm{~mm}$ 

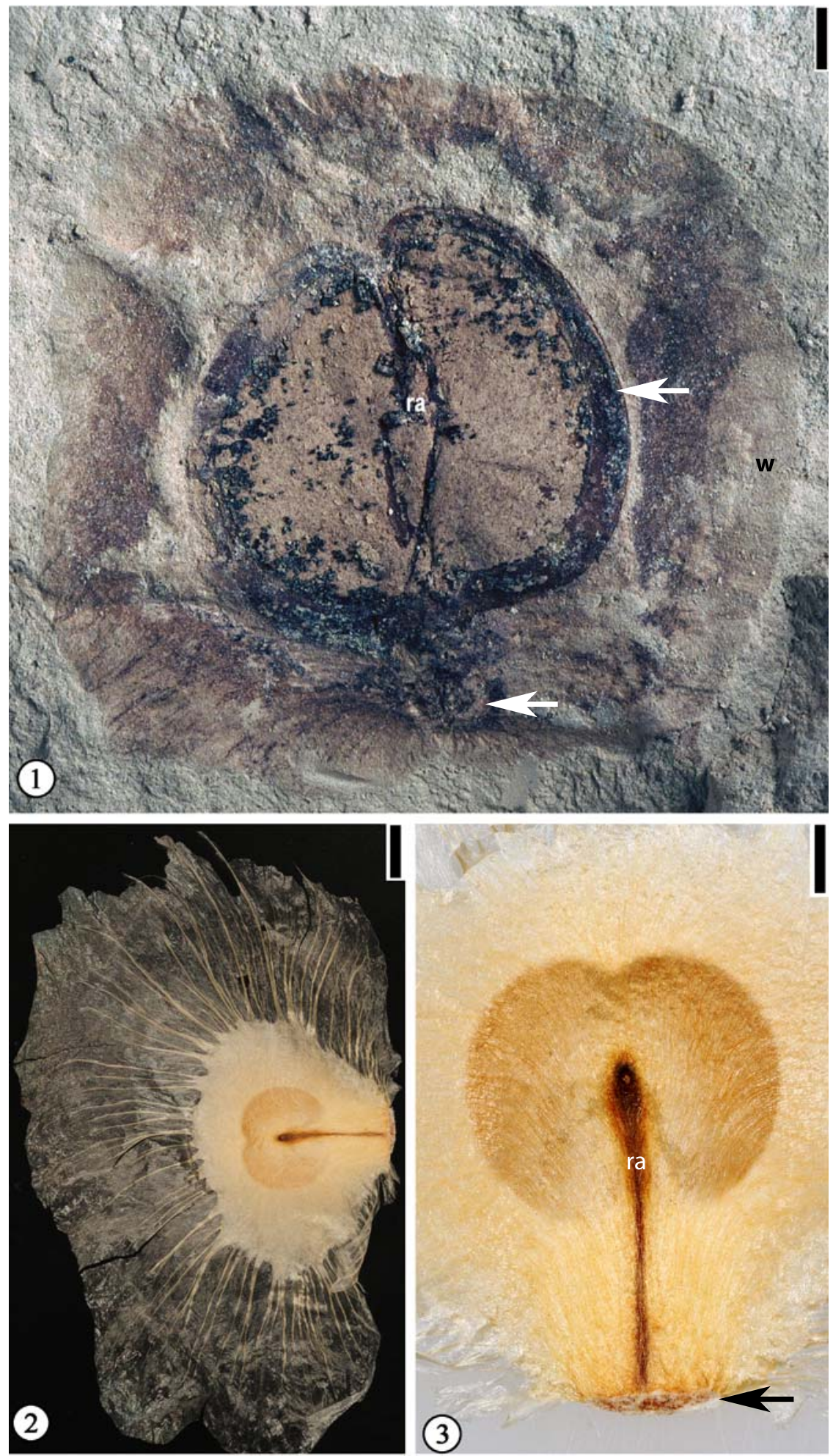

FIGURE 28. Grotea warmanensis sp. nov. 1. UF15826-51212. Outline of the seed showing a two-lobed cotyledon within a circular seed body surrounded by a wing (w) with fine striations. Note the thick seed testa (indicated by upper arrow), the raphe (ra), the hilum scar (indicated by lower arrow), and fine striations in the lower part of the wing. Scale bar $=2 \mathrm{~mm}$. 2. Pithecoctenium crucigerum (Linnaeus) Gentry, collected by J. Blanchard from Honduras, UF2218 (Modern Reference Collection).UF2218 (Modern Reference Colllection). Showing a winged seed. Scale bar $=5 \mathrm{~mm}$. 3. Enlargement of Figure 28.2 to show the cotyledon, the rahpe (ra), the hilum scar (indicated by arrow). Scale bar $=$ $2 \mathrm{~mm}$. 

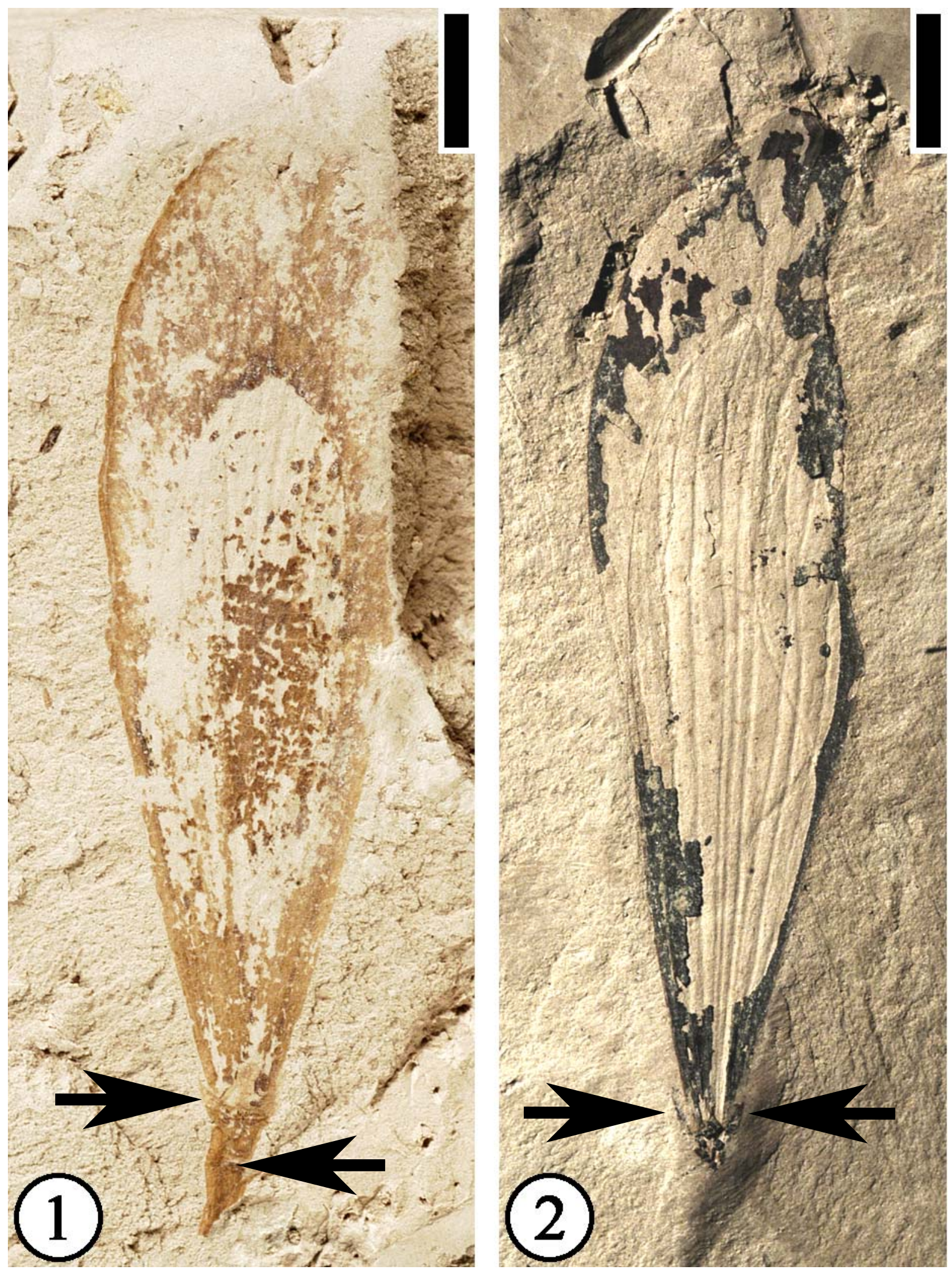

FIGURE 29. Fraxinus wilcoxiana (Berry) Call and Dilcher. All bars equal $3 \mathrm{~mm}$. 1. UF15826-1368. Showing a calyx lobe (indicated by arrow on the left), a peduncle (indicated by arrow on the right), and thin subparallel veins on fruit wing. 2. UF15826-1369. Showing calyx lobes (indicated by arrows) and longitudinally striate fruit body. 

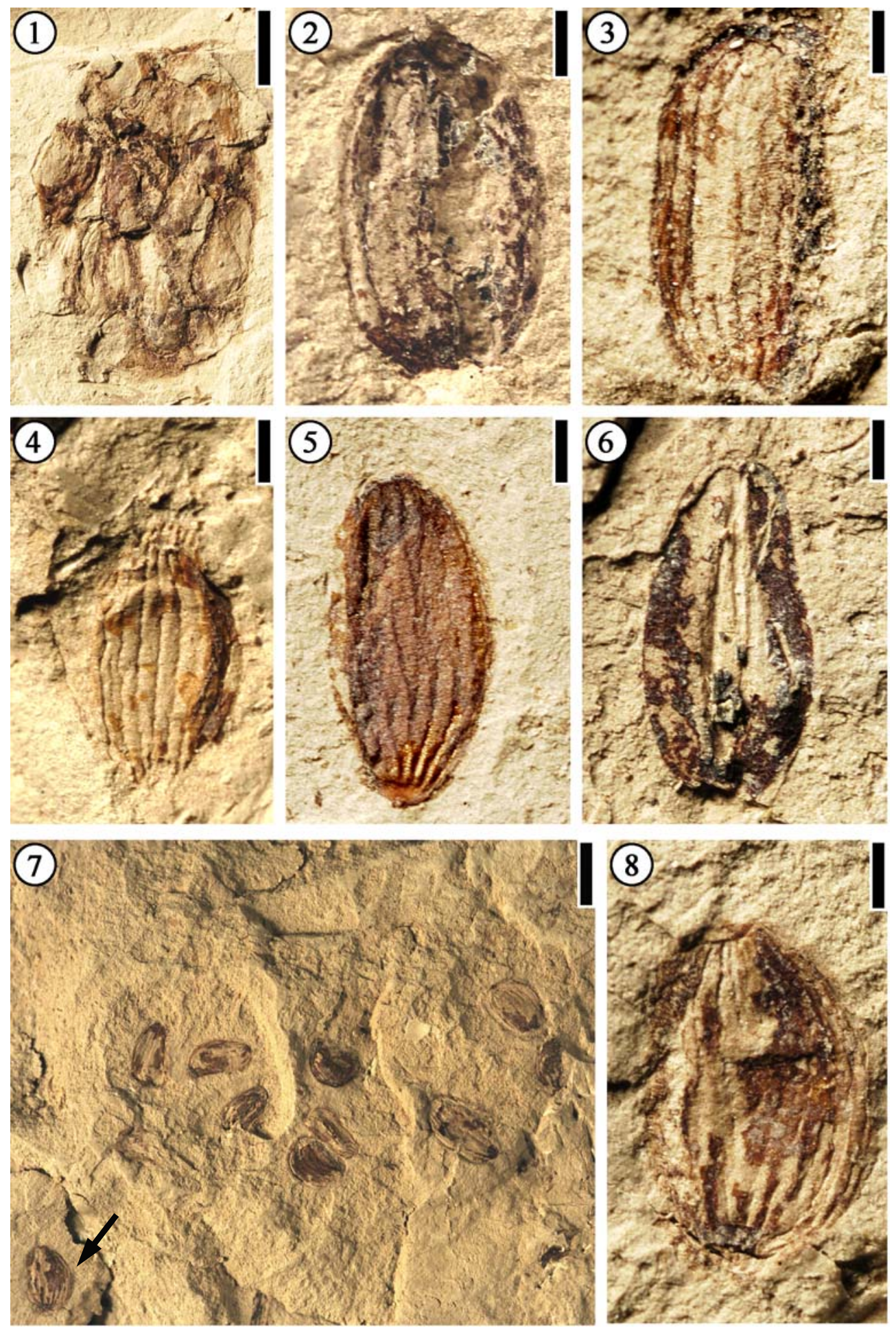

FIGURE 30. "Aralia" semina Berry. 1. UF15826-51298. A cluster of at least 10 seeds with the same orientation. Scale bar $=2 \mathrm{~mm}$. 2. UF15826-51477a. An elliptic seed. Scale bar $=0.5 \mathrm{~mm}$. 3. UF15826-51477b. A seed showing seven longitudinal striations and fine cross striations. Scale bar $=0.5 \mathrm{~mm}$. 4. UF15826-51485. A wide elliptic seed. Scale bar $=0.5 \mathrm{~mm}$. 5. UF15826-51550. A seed showing longitudinal striations and possible seed hilum on one end. Scale bar $=$ $0.5 \mathrm{~mm}$. 6. UF15826-51303. Narrow ovate seed with a prominent ridge in the middle extending to the mucronate apex, no prominent longitudinal striations but cross striations are similar to those observed in other "Aralia" seeds. Scale bar $=0.5 \mathrm{~mm}$. 7. UF15826-51483. A specimen showing 12 dispersed seeds. Scale bar $=3 \mathrm{~mm}$. 8. Enlargement of one seed from Figure 30.7 (indicated by arrow) showing longitudinal and cross striations. Scale bar $=0.5 \mathrm{~mm}$. 
long and the size of the Messel seeds is less than $4.5 \mathrm{~mm}$ long.

The possibility that these specimens may not be of plant origin cannot be ruled out. As demonstrated by Heřmanová and Kvaček (2010), some fossils described by Knobloch and Mai (1984, $1986,1991)$ were later recognized as insect eggs because they are of similar size and they both possess similar surface structures but they differ in wall structure.

\section{ANGIOSPERM INCERTAE SEDIS INFRUCTESCENCES Infructescence Type 1}

(Figure 31)

Description. Elongate infructescence $2-3 \mathrm{~cm}$ long and $1 \mathrm{~cm}$ wide with ca 20 helically arranged pedicellate fruits. Individual fruit is ca $3 \mathrm{~mm}$ in diameter. Pedicel ca $1 \mathrm{~mm}$ long.

Number of specimens examined. 15. UF1582651472 (Figure 31.1-2); 51222 (Figure 31.3); 33570 (Figure 31.4); 51440 (Figure 31.5).

Discussion. The cuticle of the compressed fruit is usually wrinkled, indicating that each fruit is possibly a berry or a drupe.

\section{Infructescence Type 2}

(Figure 32)

Description. Pedunculate infructescences ca 0.8 $\mathrm{cm}$ in diameter, each with at least seven fruits. Peduncle up to $3.6 \mathrm{~cm}$ long and $1.5-2 \mathrm{~mm}$ wide. Helically arranged appendage scars present on the peduncle. Fruits spherical, ca $3 \mathrm{~mm}$ in diameter, clustered together, a center core absent. A protrusion (persistent style?) present on each fruit. Number of specimens examined. 2. UF1582651525 (Figure 32.1-2); 51296 (Figure 32.3-5).

Discussion. This infructescence type differs from the other three types with clustered fruits in having fewer fruits in each infructescence, the presence of a style on the distal end of the fruit, and helically arranged appendage scars on the peduncle. These scars are probable vascular traces or impressions of them pushing back into the stem upon compression. These appendages could be thorns that are observed on the peduncle of some fruits in the Rosaceae (e.g., raspberry).

\section{Infructescence Type 3}

(Figure 33)

Description. Pedunculate infructescence ca 0.8 $\mathrm{cm}$ in diameter; peduncle up to $2.3 \mathrm{~cm}$ long and 1.5-2 mm wide with smooth surface (cuticle) and regularly spaced transverse "cracks." At least nine bilocular fruits in each infructescence. A central receptacle core present, ca $3-5 \mathrm{~mm}$ in diameter. Pentagonal impression present on the receptacle core, ca $2 \mathrm{~mm}$ in diameter, containing two smaller circular impressions ca $0.9 \mathrm{~mm}$ in diameter.

Number of specimens examined. 2. UF1582651328 (Figure 33.1-2); 51519, (Figure 33.3-4).

Discussion. The bilocular fruits are based upon the impressions left on the central receptacle core after the fruits are shed. This infructescence type may be related to the Altingiaceae Infructescence (Figure 7.1-2) as indicated by their bilocular nature of the fruit impressions on the receptacle core.

\section{FLORAL PARTS}

Genus ANTHOLITHES Brongniart, 1822 Antholithes wilcoxensis Berry, 1930

(Figure 34)

1930 Antholithes wilcoxensis Berry, p. 141, pl. 50, figs. 6,7 .

Description. Vertically compressed flower containing five triangular perianth parts (calyx), each ca $1.0 \mathrm{~mm}$ long and $1.5 \mathrm{~mm}$ wide at the base. Relatively large ovary ca $2 \mathrm{~mm}$ in diameter, hypogenous within the perianth-cup. Pedicel $4 \mathrm{~mm}$ long and $0.5 \mathrm{~mm}$ wide.

Number of specimens examined. 1. UF1582633555 (Figure 34).

Discussion. This pentamerous flower is similar to the single flower described by Berry (1930, p. 141, pl. 50 , figs. 6,7 ). The inferior ovary is indicated by a central depression below the five perianth parts. It differs from Solanites pusillus Berry (see below; Figure 35) in having five smaller and triangular perianth parts.

\section{Genus SOLANITES Saporta, 1862 Solanites pusillus Berry, 1930}

(Figure 35)

1930 Solanites pusillus Berry, p. 132, plate 48, figures 21-23.

Description. Vertically compressed flower containing five perianth parts, each ca $4 \mathrm{~mm}$ long and 2 $\mathrm{mm}$ wide. Perianth parts free from each other. Ovary inferior, ca $2.5 \mathrm{~mm}$ in diameter.

Number of specimens examined. 1. UF1582633561 (Figure 35).

Discussion. Based upon gross morphology, this pentamerous flower is the same type identified as Solanites pusillus by Berry (1930, p. 132, plate 48, figures 21-23). This floral type is also present in other localities of southeastern United States (personal observation). It differs from other flowers by its smaller, conically shaped inferior ovary. The inferior ovary is inferred by the conical depression, 

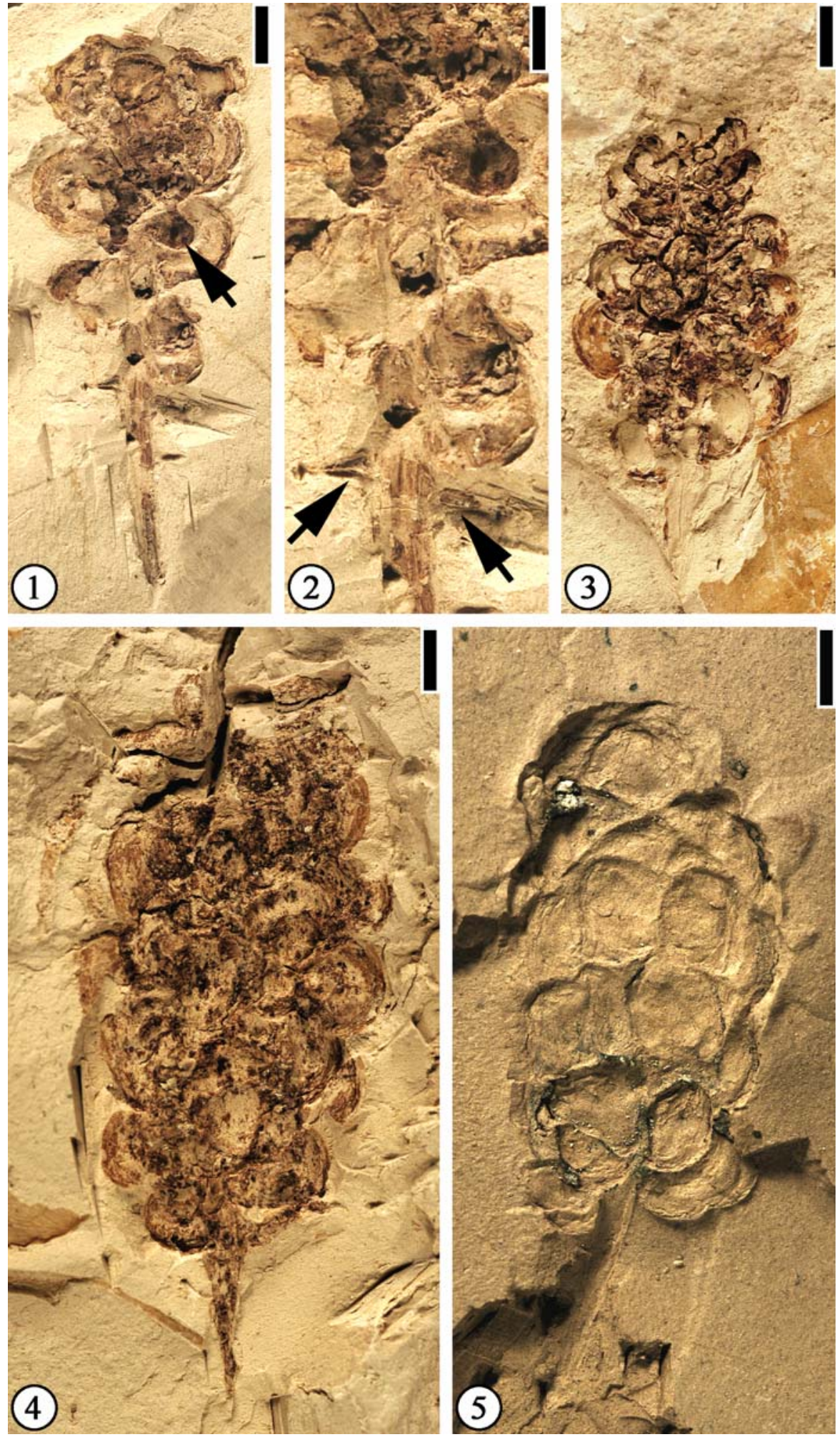

FIGURE 31. Infructescence Type 1. 1. UF15826-51472. Attached fruits at the distal portion. The depression in the center of a fruit (indicated by the arrow) may represent a hard seed of the fruit. Scale bar $=2 \mathrm{~mm}$. 2 . Enlargement of Figure 31.1 to show pedicels of shed fruits (indicated by arrows). Scale bar $=1 \mathrm{~mm}$. 3. UF15826-51222. Distal portion of an infructescence. Scale bar $=2 \mathrm{~mm}$. 4. UF15826-33570. An infructescence with at least 15 fruits. Scale bar $=2$ $\mathrm{mm}$. 5. UF15826-51440. An infructescence with impressions of at least 15 fruits. Scale bar $=3 \mathrm{~mm}$. 

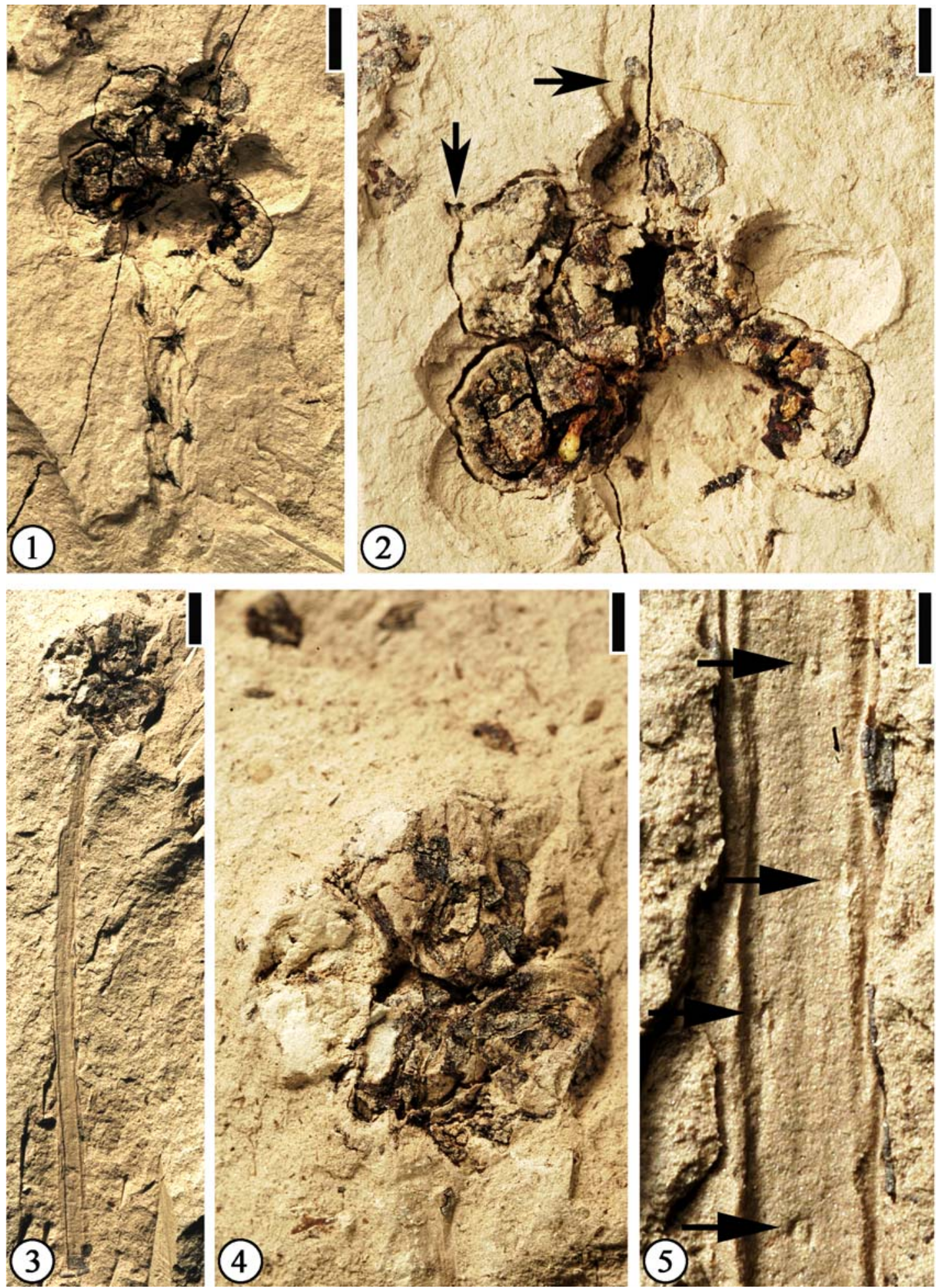

FIGURE 32. Infructescence Type 2. 1. UF15826-51525. An infructescence with about 7 attached fruits. Scale bar $=2$ $\mathrm{mm}$. 2. Enlargement of Figure 32.1 to show persistent styles on the fruits (indicated by the arrows). Scale bar $=1$ $\mathrm{mm}$. 3. UF15826-51296. An infructescence with a long peduncle. Scale bar $=2 \mathrm{~mm}$. 4. Enlargement of Figure 32.3 to show clustered fruits. Scale bar $=1 \mathrm{~mm}$. 5 . Enlargement of Figure 32.3 to show impression of the appendage scars on the peduncle (indicated by the arrows). Scale bar $=0.5 \mathrm{~mm}$. 

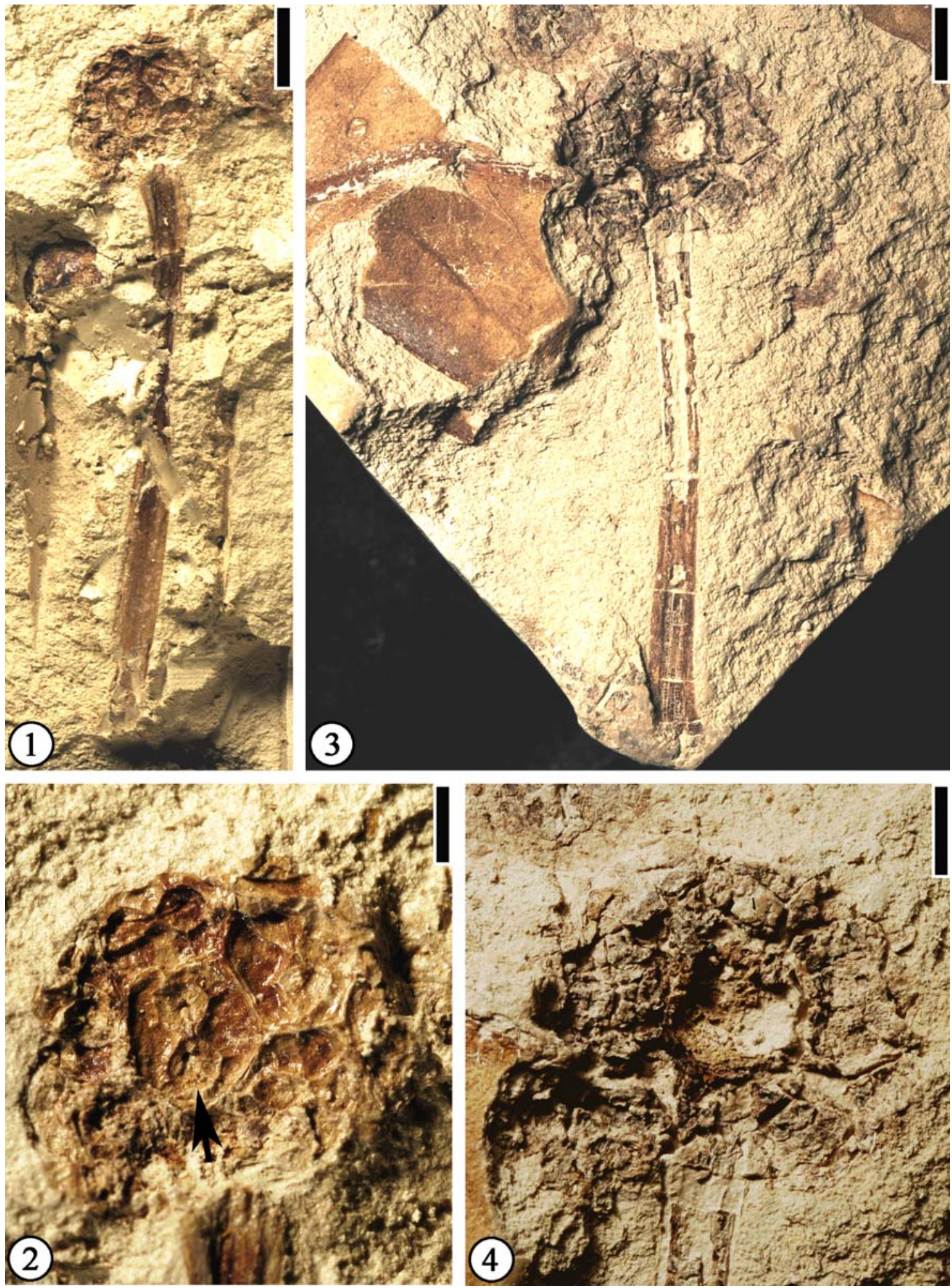

FIGURE 33. Infructescence Type 3. 1. UF15826-51328. Impression of an infructescence and a long peduncle with smooth surface. Scale bar $=3 \mathrm{~mm}$. 2. Enlargement of Figure 33.1 to show impressions of the bicarpellate fruits. Arrow indicates one of the two circular impressions within the larger pentagonal impression. Scale bar $=1 \mathrm{~mm}$. 3. UF1582651519. An infructescence and long peduncle with smooth surface. Scale bar $=3 \mathrm{~mm}$. 4 . Enlargement of Figure 33.3 to show impression of a central receptacle core. Scale bar $=2 \mathrm{~mm}$. 


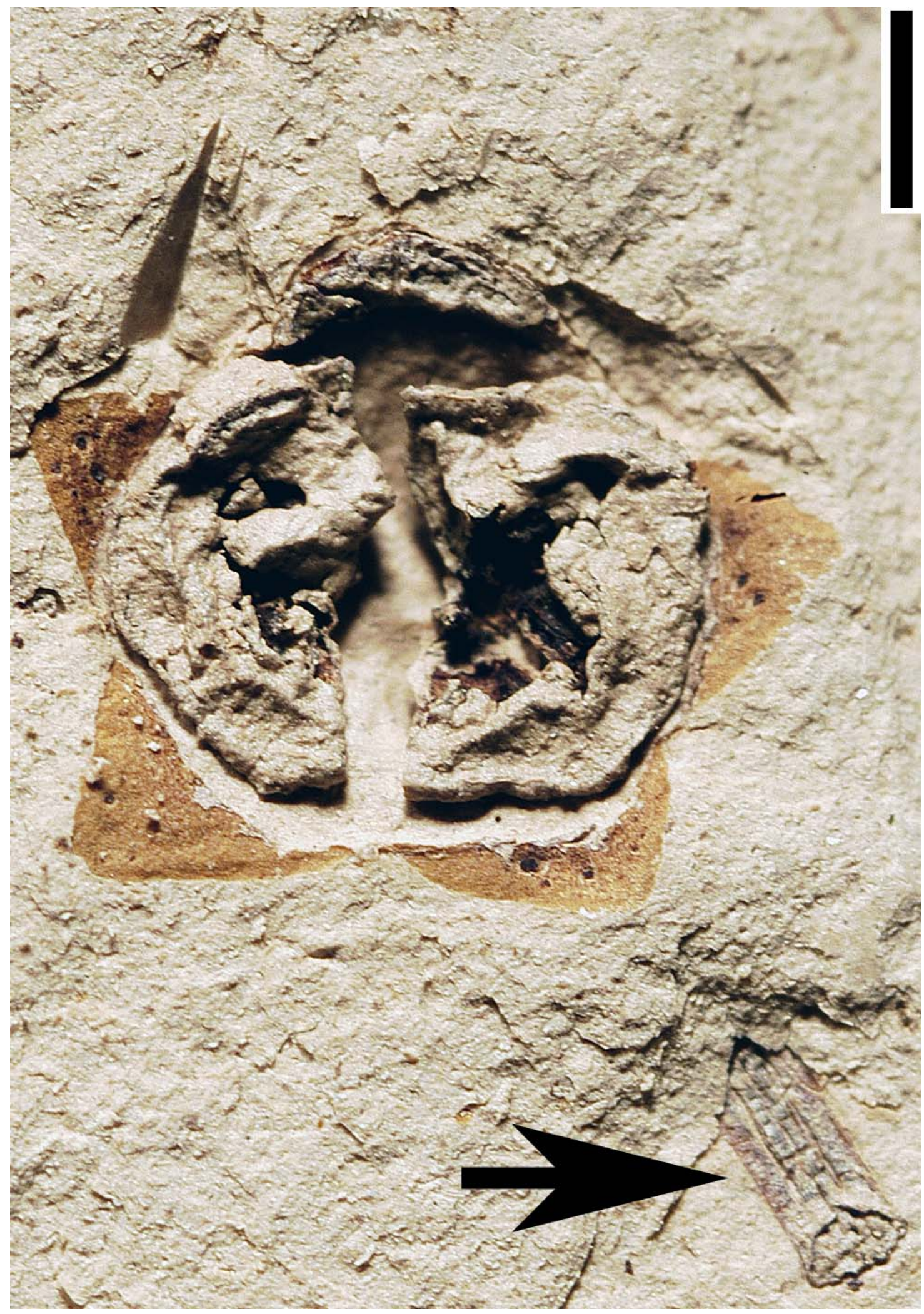

FIGURE 34. Antholithes wilcoxensis Berry. UF15826-33555. A flower showing five triangular perianth parts, an ovary, and a pedicel (indicated by the arrow; degauging confirmed that it is physically connected to the flower). Scale bar $=1$ $\mathrm{mm}$. 
which is below the surface of the perianth parts. Berry $(1916,1930)$ assigned these flowers to the Solanaceae. However, Martinez-Millan (2010a, b) suggested that these flowers, including Solanites saportana, S. crassus, and S. sarachaformis, do not possess characters of the Solanaceae and that S. pusillus may belong to the Rhamnaceae based upon that family's typically small pentamerous flowers with cupulate hypanthium ending in a thick presumably nectariferous rim, triangular sepals with a prominent midvein, thin clawed cucullate petals alternating with the sepals and stamens opposite the petals.

Calvillo-Canadell and Cevallos-Ferriz (2007) reported some fossil flowers from the Late Cretaceous (late Campanian) Cerro del Pueblo Formation at El Almácigo locality in General Cepeda County, Coahuila, Mexico. The small actinomorphic pentamerous Cretaceous flowers are assigned to Coahuilanthus belindae Calvillo-Canadell and Cevallos-Ferriz within the Rhamnaceae based upon their morphological similarity with Rhamneae (Rhamnus and Sagertia) and Zizypheae (Berchemia).

Floral Morphotype 1

(Figure 36.1-2)

Description. Laterally compressed flower $4.5 \mathrm{~mm}$ long and $4.5 \mathrm{~mm}$ wide with five perianth parts fused for about half of their length. Free portions of the perianth triangular, $2 \mathrm{~mm}$ long and $1.5 \mathrm{~mm}$ wide. Fused basal portion of the perianth forming a funnel-shaped hypanthium ca $1 \mathrm{~mm}$ in diameter.

Number of specimens examined. 1. UF1582633560 (Figure 36.1-2).

Discussion. The flower is laterally compressed with only five perianth parts preserved. This flower is different from Floral Morphotype 2 (Figure 36.3, 4 ) in its small size, the absence of trichomes on the perianth, and a funnel-shaped hypanthium. This specimen is similar to a specimen illustrated by Crepet (1979, plate VIII fig. 5), but differs in having triangular perianth parts. This flower differs from Solanites pusillus Berry in that it has fused perianth parts and no trichomes. This flower seems to have an inferior ovary.

Floral Morphotype 2

(Figure 36.3-4)

Description. Laterally compressed flower ca 11 $\mathrm{mm}$ long and $12 \mathrm{~mm}$ wide (including pedicel). Five perianth parts of different sizes, fused for half of their length. Middle perianth part ca $6 \mathrm{~mm}$ long (measured from the apex to the ovary) and $4 \mathrm{~mm}$ wide with acute apex; free portion of middle peri- anth part $4 \mathrm{~mm}$ long and $4 \mathrm{~mm}$ wide, triangular; free portion of two inner lateral perianth parts $3 \mathrm{~mm}$ long and $3 \mathrm{~mm}$ wide; free portion of two outside lateral perianth parts elliptic, $2 \mathrm{~mm}$ long and $1.5 \mathrm{~mm}$ wide. Trichomes present on the abaxial surface. Pedicel short, ca $2 \mathrm{~mm}$ long and $1 \mathrm{~mm}$ wide. Ovary superior, ca $1 \mathrm{~mm}$ in diameter.

Number of specimens examined. 1. UF1582651276 (Figure 36.3-4).

Discussion. The flower is laterally compressed. The ovary is represented by a depression at the base of the flower. The size change of the perianth parts could be the result of the preservation or could be that the flower is bilaterally symmetrical. It differs from Floral Morphotype 1 (Figure 36.1, 2) in its superior ovary, larger size and the presence of trichomes on the perianth parts, which are fused for half of their length. It differs from the specimen illustrated by Crepet (1979, plate VIII, fig. 5) in having triangular perianth parts and trichomes. It differs from Eoglandulosa warmanensis (Taylor and Crepet, 1987; also see Figure 21.1-2) in having fused perianth parts.

\section{Floral Morphotype 3}

(Figure 37)

Description. Vertically compressed flower with 5 obovate perianth parts free from each other with each ca $2.5 \mathrm{~mm}$ long and $1 \mathrm{~mm}$ wide. Apex of each perianth part rounded. Ovary ca $1.0 \mathrm{~mm}$ in diameter.

Number of specimens examined. 1. UF1582633553 (Figure 37).

Discussion. This flower is similar to Eoglandulosa warmanensis Taylor and Crepet (Taylor and Crepet, 1987) in having five perianth parts. However, the diagnostic features, including clawed petals, indumenta of two-branched hairs, and tricolporate pollen with reticulate ornamentation of Eoglandulosa warmanensis are not observed on this specimen. It differs from other Warman flowers in having a very small ovary.

Floral Morphotype 4

(Figure 38)

Description. Vertically preserved flower with five overlapping perianth parts and a central ovary observed. Perianth ovate, ca $10 \mathrm{~mm}$ long and 7 $\mathrm{mm}$ wide, surrounding a central ovary ca $2 \mathrm{~mm}$ in diameter. Venation obvious along the long axis of the fused perianth with thin veins forking two or three times before reaching the margin. Simple trichomes present on the perianth, more abundant close to the ovary. 


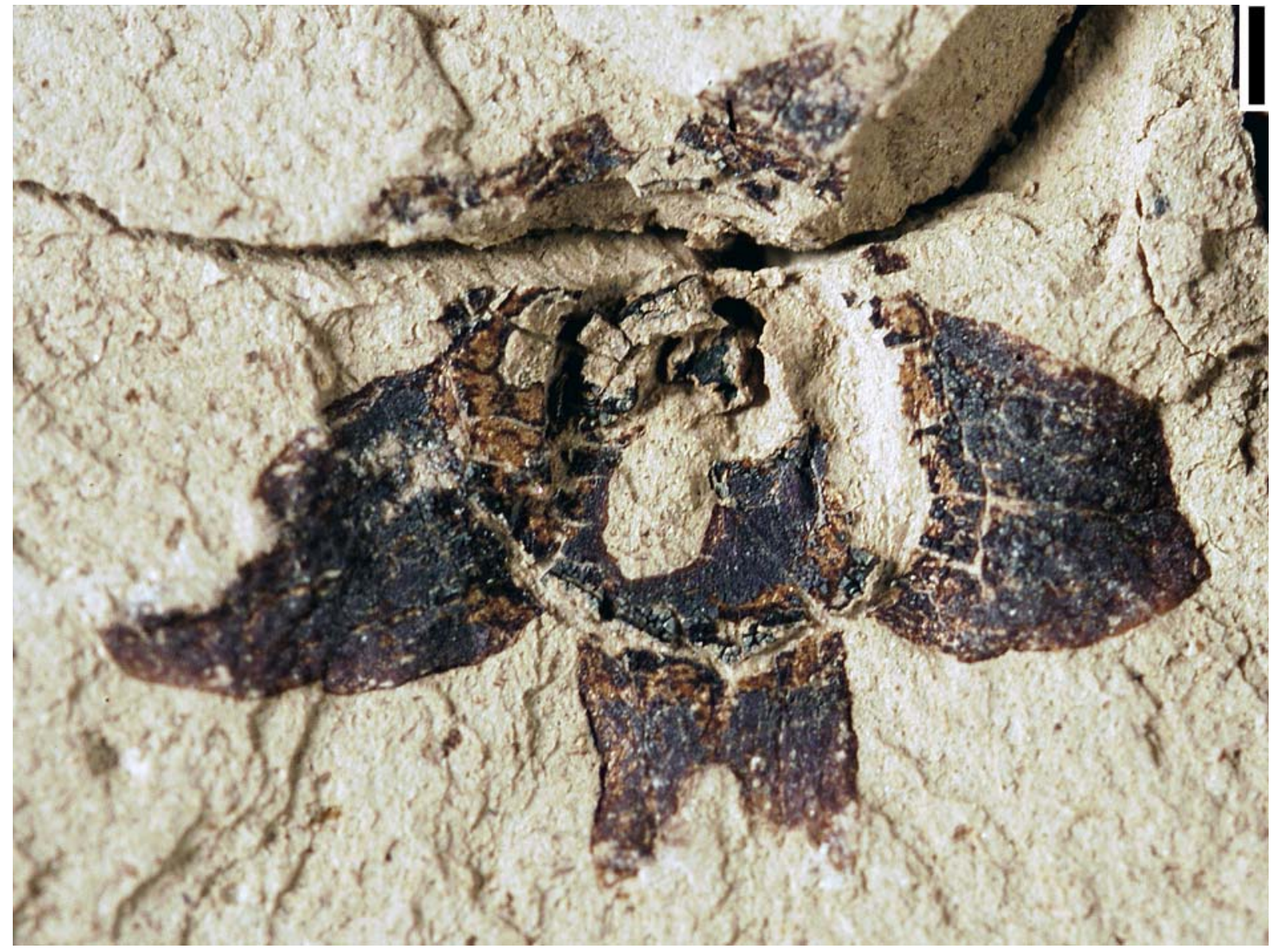

FIGURE 35. Solanites pusillus Berry. UF15826-33561. An incomplete specimen showing five separate perianth parts. Scale bar $=0.5 \mathrm{~mm}$.

Number of specimens examined. 1. UF1582651304 (Figure 38).

Discussion. The flower has five overlapping perianth parts, which distinguishes it from all other known floral specimens from the Warman clay pit. In gross morphology, this flower is similar to the Eocene flower, Dillhoffia cahcensis, from McAbee, British Columbia (Manchester and Pigg, 2008) in that they both have fused (or connate) perianth parts. They differ in that the flower from the Warman clay pit is smaller and it does not possess radiating veins that bifurcate and loop near the margin.

\section{Floral Morphotype 5}

(Figure 39)

Description. Vertically preserved flowers ca 2.3$2.6 \mathrm{~cm}$ in diameter (including perianth parts) with five persistent perianth parts and a hypogynous ovary containing five triangular carpels. Ovary 5 $\mathrm{mm}$ in diameter. Receptacle $5 \mathrm{~mm}$ in diameter. Perianth parts separate, each part 7-10 mm long,
5-7 mm wide, containing one major medial vein, and 3-4 thinner, parallel veins on each side. Medial vein extending to the apex and thinner veins branching at various distances from the base to form minor veins.

Number of specimens examined. 14. UF158265908 (Figure 39.1-2); 33552 (Figure 39.3); 49556 (Figure 39.4).

Discussion. When we searched on INTKEY (Watson and Dallwitz, 1992) using a set of characters including perianth with distinct calyx and corolla, fertile gynoecium present, ovary 5 locular, perianth/ corolla 5 , gynoecium 5 carpelled, corolla 1 whorled, 33 families remain. Based upon available characters, we are unable to assign these fossils to any extant family. Another possibility is that these specimens may represent a winged fruit with five carpels.

Floral Morphotype 6

(Figure 40) 

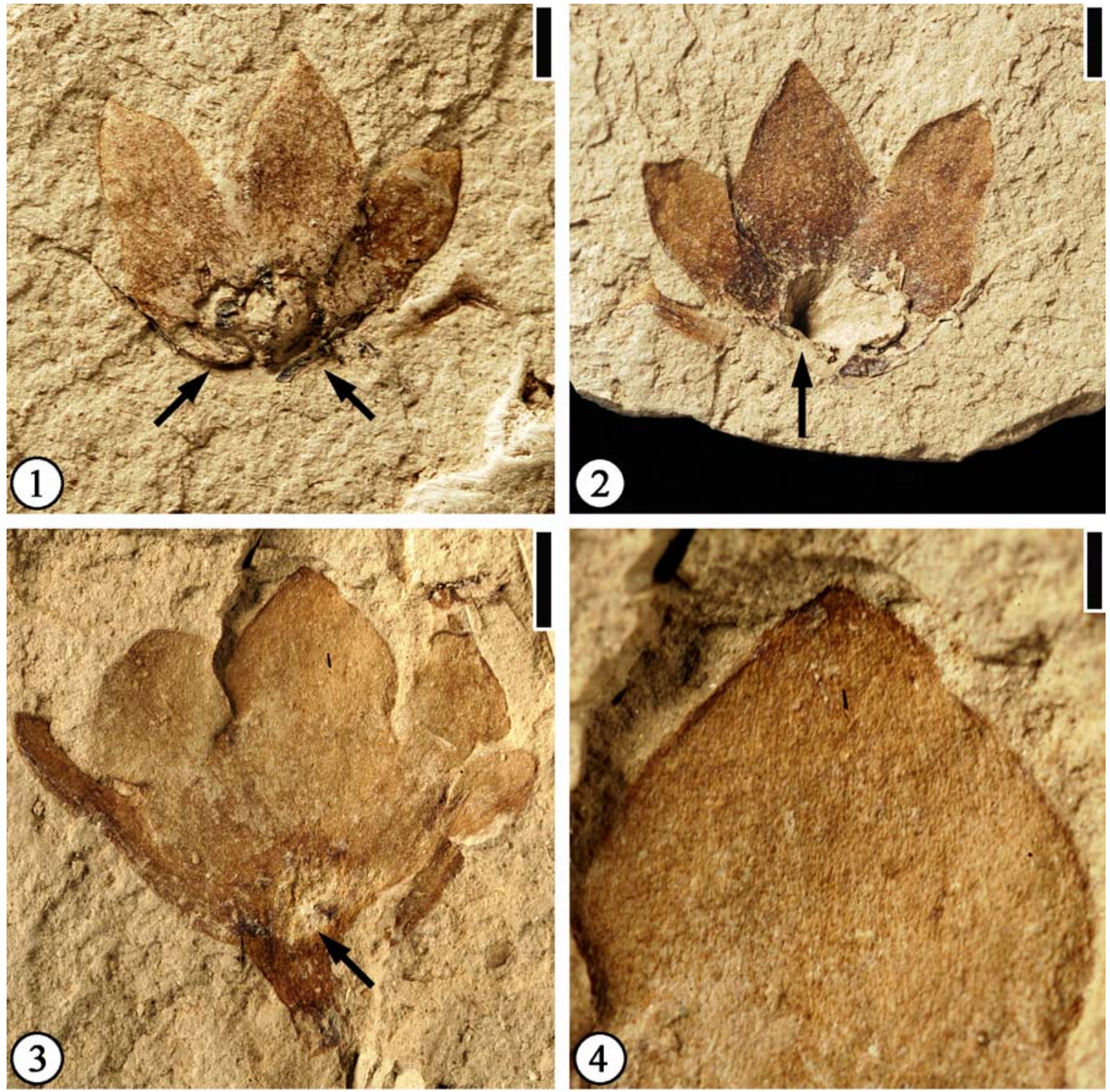

FIGURE 36. Floral Morphotype 1. 1. UF15826-33560. A laterally compressed flower showing three perianth parts fused at the base. The other two perianth parts are embedded in the matrix (indicated by two arrows). Scale bar $=1$ $\mathrm{mm}$. 2. Counterpart of Figure 36.1 to show hypanthium (indicated by arrow) and the fused perianth parts. Scale bar $=$ $1 \mathrm{~mm}$. Floral Morphotype 2. 3. UF15826-51276. A laterally compressed flower showing at least 5 perianth parts and an ovary (indicated by arrow). Scale bar $=2 \mathrm{~mm}$. 4 . Enlargement of Figure 36.3 to show trichomes on a perianth part. Scale bar $=0.5 \mathrm{~mm}$.

Description. Laterally compressed floral structure, widely elliptic, $1.4 \mathrm{~cm}$ long and $1 \mathrm{~cm}$ wide, attached to a peduncle 6 to $8 \mathrm{~mm}$ long and $2 \mathrm{~mm}$ wide. Simple trichomes present on the superimposed floral parts.

Number of specimens examined. 3. UF1582651282 (Figure 40.1-2); 51467; 51492.

Discussion. Superimposed parts of the structure (Figure 40.1, 2) with trichomes indicate that these structures may represent flower buds.

\section{FRUITS AND SEEDS}

Genus Carpolithus Linnaeus, 1768 Carpolithus collinsi (Berry) comb. nov.

(Figure 41)

1930 Laurus collinsi Berry, p. 117, pl. 19, fig. 2; pl. 49, fig. 9.

Description. Fruit impression wide elliptic or orbicular, $0.8-1 \mathrm{~cm}$ long and $0.7-1 \mathrm{~cm}$ wide. Each fruit attached to a peduncle $0.7-2.4 \mathrm{~cm}$ long and up to 2 $\mathrm{mm}$ wide. A strong triangular receptacle present. 


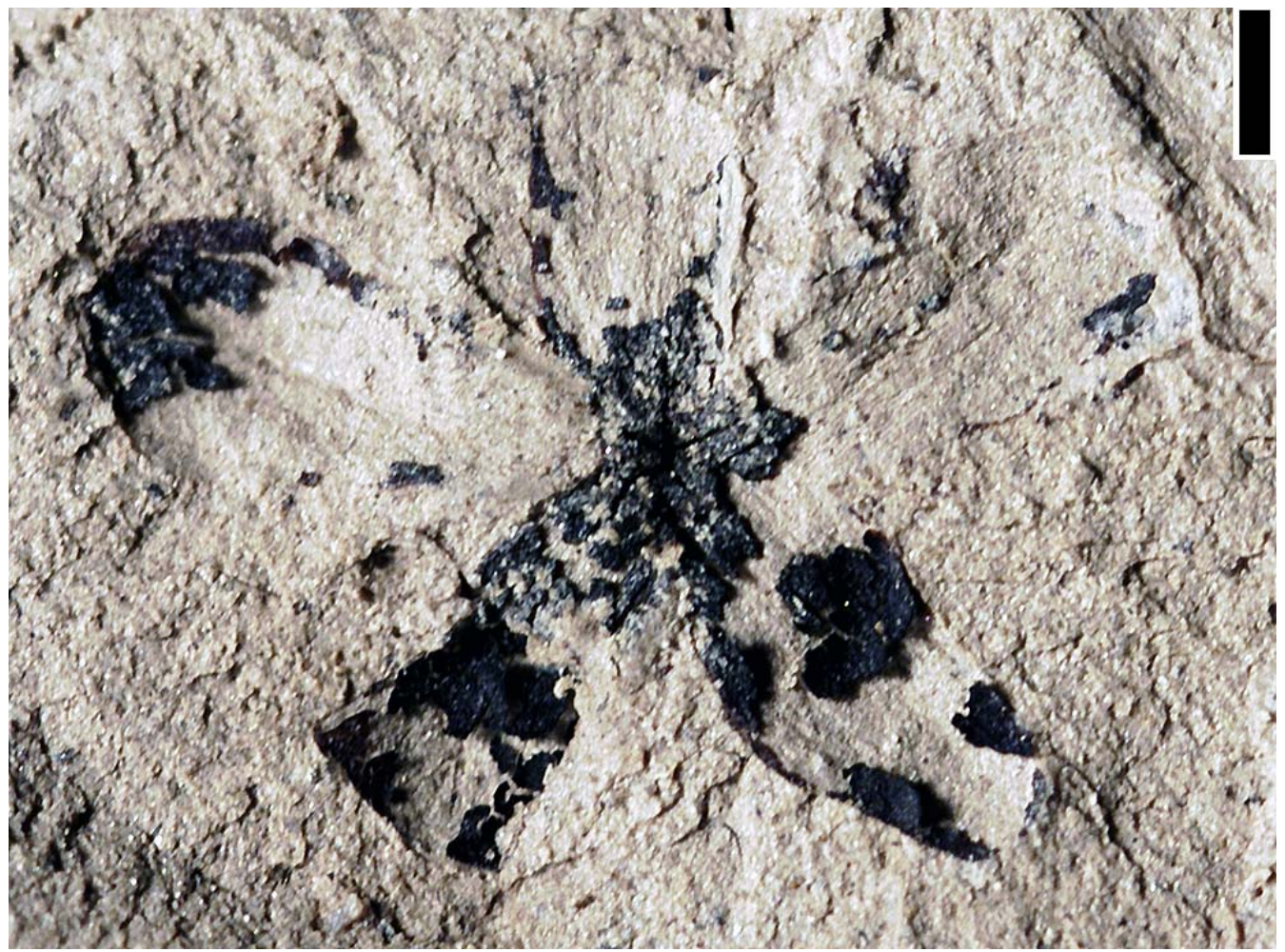

FIGURE 37. Floral Morphotype 3. UF15826-33553. Five separate perianth parts and a small ovary. Scale bar $=0.5$ $\mathrm{mm}$.

Fruit consisting of a lower cupule and an upper fruit body which are delineated by a transverse depression in the middle or lower portion of the fruit. Longitudinal striations present on both parts.

Number of specimens examined. 3. UF158156894 (Figure 41.1); 51238 (Figure 41.2), 51487 (Figure 41.3).

Lectotype. Berry (1930), pl. 19, fig. 2, p. 117.

Discussion. Berry (1930) described two specimens from the Holly Springs sand in Fayette County, Tennessee, assigning them to the modern genus Laurus. Based upon the presence of lauraceous flowers and leaves at the same locality, it is reasonable to relate these specimens to Lauraceae. Although their gross morphology is similar to the fruits of Cinnamomun and Sassafras, their assignment to extant genera cannot be assessed until more characters are available. In addition, fruits of the Lauraceae are generally deciduous, falling out of the receptacle rather than being retained. We place these specimens in Angiosperm Insertae Sedis based upon available characters and transfer them to the fossil-genus Carpolithus.

Berry (1930) did not designate a type specimen for the new species he established. Based upon International Code of Botanical Nomencla- ture (McNeill et al., 2012), we here designate the first specimen he illustrated (Berry, 1930, pl. 19, fig. 2 ) as the lectotype.

The transverse depression in the middle of the fruits resembles that of the myrtaceous fruits from the Eocene of the Rocky Mountain region (Manchester et al., 1998). Myrtaceous leaves are also present at the Warman locality and other Claiborne Group localities in Tennessee (Dilcher and Lott, 2005; personal observation). However, fruits of Carpolithus collinsi are larger than those specimens from the Eocene of the Rocky Mountain region and they do not possess the persistent style that has a capitate stigma.

Carpolithus complanata (Lesquereux) comb. nov. (Figure 42)

1904 Nyssa curta Perkins, p. 199, pl. 79, fig. 111. 1930 Nyssa curta Perkins, Berry, p. 125, plate 19, fig. 10.

1963 Nyssa complanata Lesquereux, Eyde and Barghoorn, p.351, figs. 5, 15-19.

Description. Seed broadly elliptic, $7.5 \mathrm{~mm}$ long and $5 \mathrm{~mm}$ wide. Three longitudinal ridges and two grooves present.

Number of specimens examined. 1. UF1582651486 (Figure 42). 


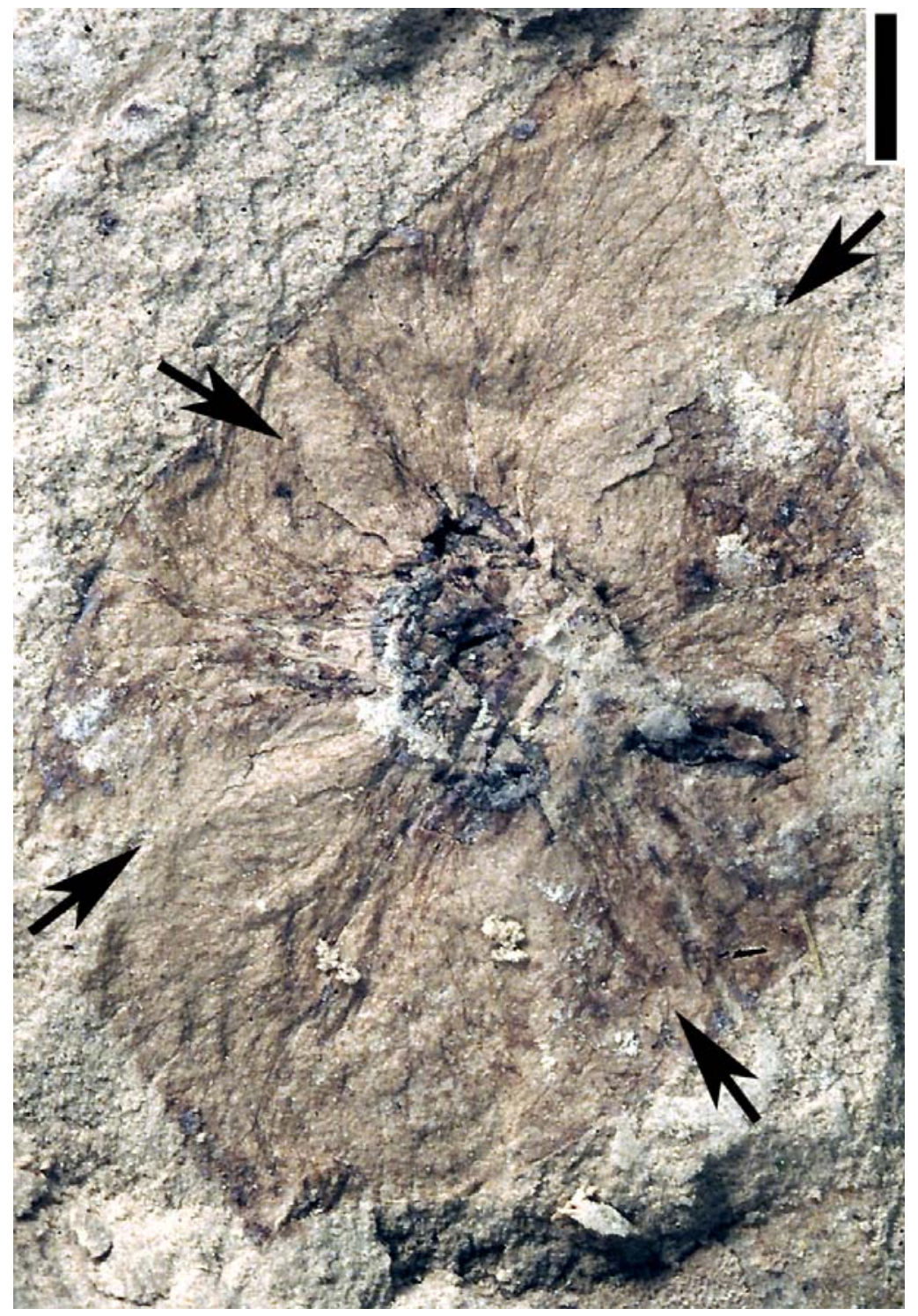

FIGURE 38. Floral Morphotype 4. UF15826-51304. A flower with five overlapping perianth parts. Arrows indicate positions where the perianth parts overlapp. Scale bar $=1 \mathrm{~mm}$.

Discussion. In gross morphology, this impression specimen seems to match the lignified specimen from the Holly Springs locality, Tennessee described by Berry (1930). Eyde and Barghoorn (1963) put Nyssa curta in synonym with Nyssa complanata. We feel that available characters do not warrant its assignment to the extant genus Nyssa and propose that these specimens be transferred to the fossil-genus Carpolithus.

\section{Carpolithus prangosoides Berry, 1916}

(Figure 43)

1916 Carpolithus prangosoides Berry, p. 351, pl. 104, figure 9.
1916 Carpolithus henryensis Berry, p. 352, pl. 112, fig. 16.

1926 Terminalia vera Berry, p. 61, figs. 1-5.

1930 Terminalia vera Berry, pp.119-122, plate 49, figs. 21-27.

Description. Fruit elliptic, $1.7 \mathrm{~cm}$ long and $1.2 \mathrm{~cm}$ wide. Five longitudinally attached lateral wings present, each $5 \mathrm{~mm}$ wide at the middle and apical portion of the fruit, fused at the apex, with reticulate venation. Seed body $12 \mathrm{~mm}$ long and $5 \mathrm{~mm}$ wide, narrowly elliptic. Longitudinal striations and a strong middle ridge present on the seed.

Number of specimens examined. 2. UF1582651403 (Figure 43). 

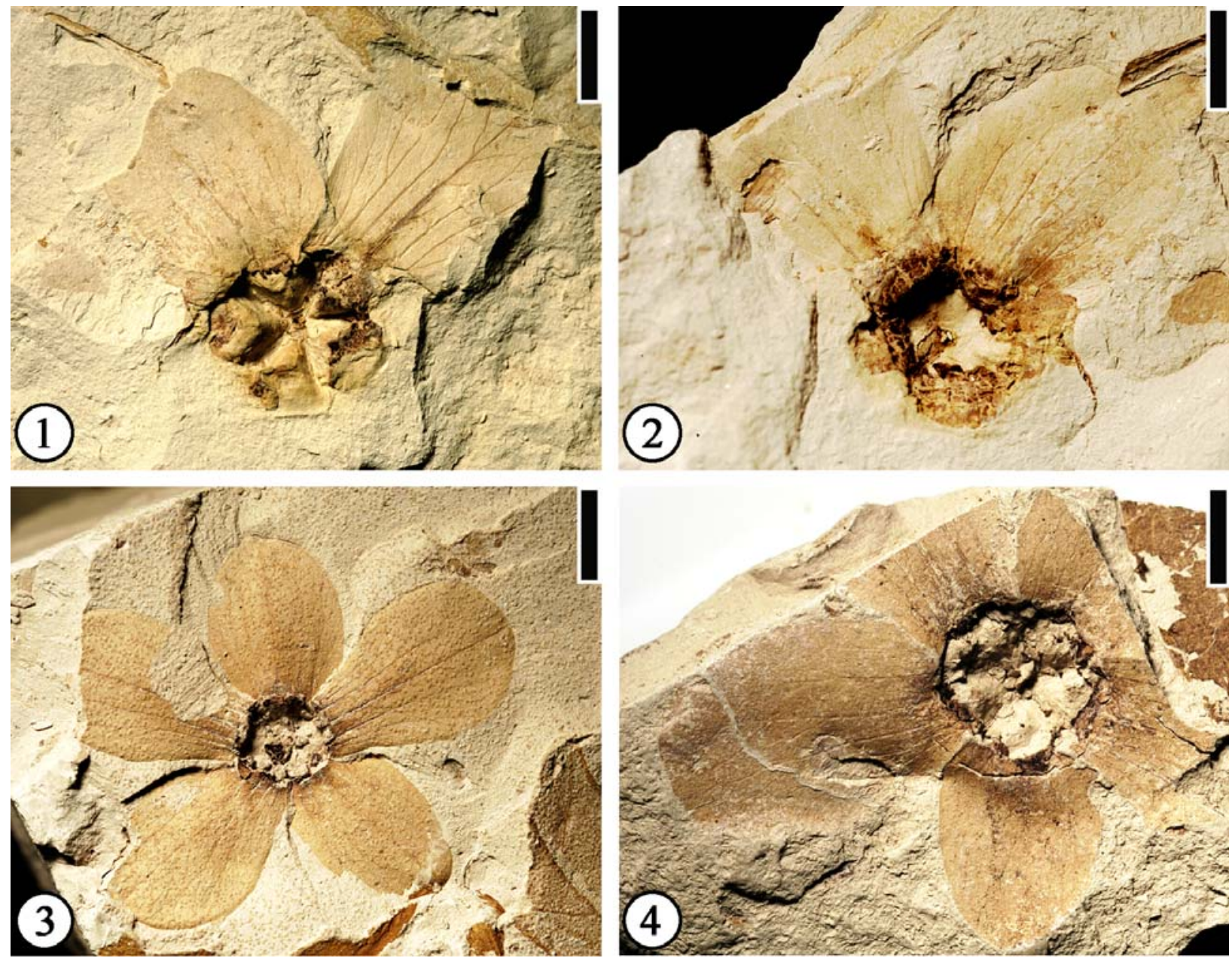

FIGURE 39. Floral Morphotype 5. 1. UF15826-5908. A superior ovary with 5-lobed gynoecium and surrounding perianth. Scale bar $=3 \mathrm{~mm}$. 2. Counterpart of Figure 39.1 showing a receptacle and reticulate venation on perianth. Scale bar $=3 \mathrm{~mm}$. 3. UF15826-33552. Five obovate perianth parts. Note parallel major veins of perianth. Scale bar $=4 \mathrm{~mm}$. 4. UF15826-49556. A superior ovary with five radially arranged carpels. Scale bar $=3 \mathrm{~mm}$.

Discussion. This winged fruit type is common in the middle Eocene clay pits in Tennessee and Kentucky. Berry (1916) first described them as Carpolithus prangosoides. He later (1926, 1930) assigned similar specimens to Terminalia vera. However, O'Leary (2007) suggested that the taxonomic affinities of these fruits should be considered uncertain based upon the present state of knowledge and detailed comparison of wing venation of the fossil fruits and extant Terminalia. The winged fruits were initially interpreted either as a capsule or as a bi-winged fruit (Berry, 1916, 1926, 1930). Examination of many specimens by O'Leary (2007) indicates that the fruits are indehiscent and have multiple wings. The assignment of these fossil fruits to Combretaceae by Berry (1916, 1926, 1930 ) is rejected. Terminalia vera is placed in syn- onymy under the earlier name Carpolithus prangosoides.

\section{Carpolithus sophorites Berry, 1916 \\ (Figure 44)}

Description. Disseminule spherical or ovoid, 1.5$1.6 \mathrm{~cm}$ long and $1.2-1.3 \mathrm{~cm}$ wide, with a very thin wall. Small glands present. A longitudinal groove present, extending almost the entire length of the disseminule body. Longitudinal folds may also be present.

Number of specimens examined. 4. UF1582651382 (Figure 44.1); 51517 (Figure 44.2); 51545 (Figure 44.3); 51288 (Figure 44.4).

Discussion. The longitudinal groove of the disseminule probably resulted from the partition of the septum or division between cotyledons. This disseminule differs from other types in having a longi- 

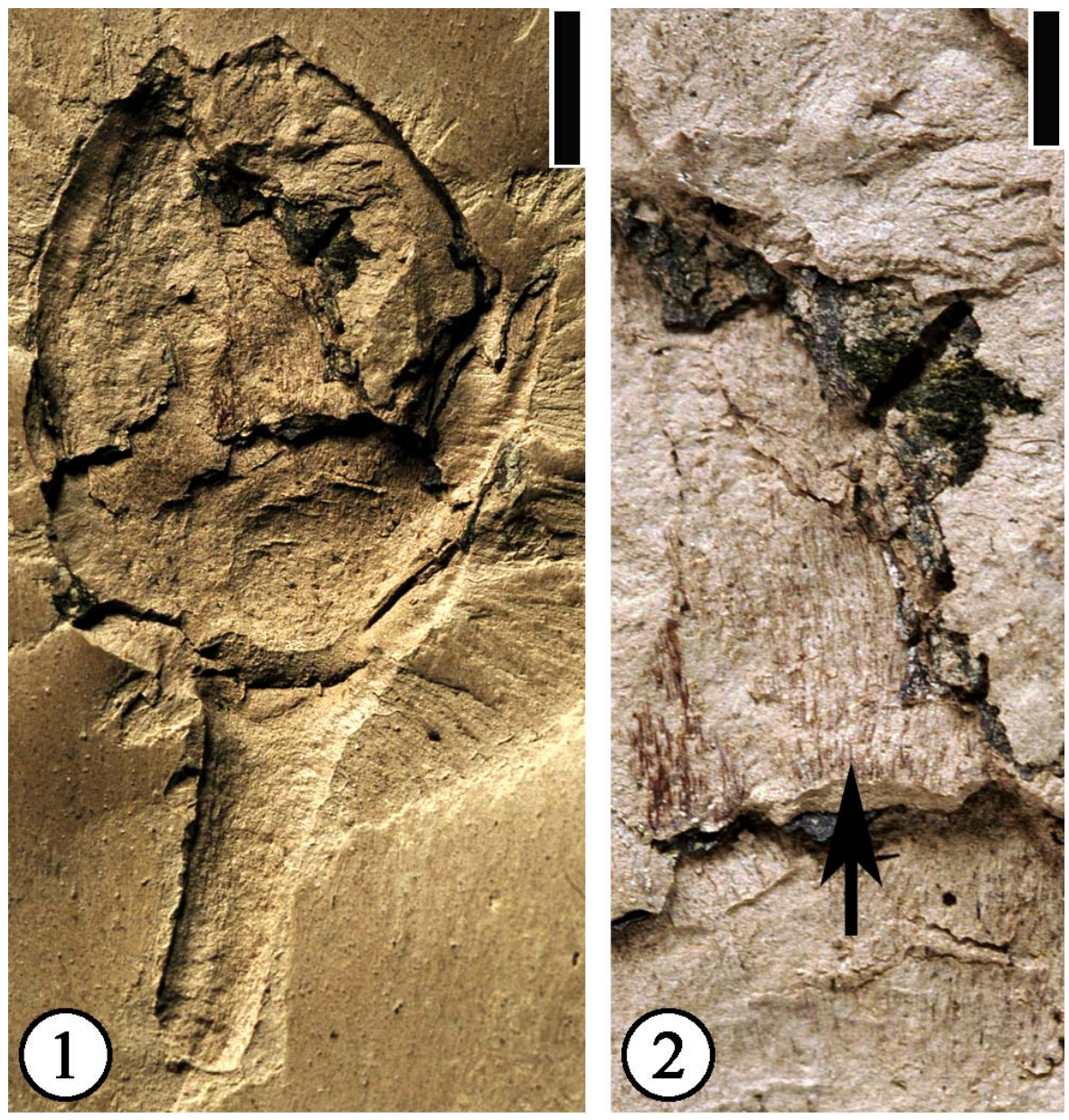

FIGURE 40. Floral Morphotype 6. 1. UF15826-51282. A flower bud with superimposed floral parts. Scale bar $=3 \mathrm{~mm}$. 2. Enlargement of Figure 40.1 showing simple trichomes (indicated by arrow). Scale bar $=1 \mathrm{~mm}$.

tudinal groove and a thin wall, and in the presence of glands on the surface.

This compressed disseminule is the same as the one specimen described by Berry (1916, p. 352, plate CXII, fig. 7.). Their modern affinity is uncertain. These specimens may represent the inside mold of the Sapotaceae seeds described by Grote (1989, p. 162-171, plate IV, figures 1-3, 5, 6; plate $\mathrm{V}$, figures 4,5 ). If this is the case, the longitudinal groove on the mold may represent the basilateral hilar scar of the seed.

\section{Carpolithus warmanensis sp. nov.}

(Figure 45)

Diagnosis. Fruit reniform, covered with spines.

Description. Fruit reniform, $12.5 \mathrm{~mm}$ long and 7 $\mathrm{mm}$ wide; seed $9.5 \mathrm{~mm}$ long and $6 \mathrm{~mm}$ wide. Spines present, ca $0.2-0.4 \mathrm{~mm}$ long, on the left half of the exocarp; small depressions present on the right half.
Holotype. Designated here. UF15826-51471 (Figure 45).

Number of specimens examined. 1.

Species epithet. Referring to its occurrence at the Warman clay pit locality.

Discussion. This unique specimen represents a fruit with a spiny exocarp. The seed is defined by a $0.5-1 \mathrm{~mm}$ dark zone, which is more obvious on the right half. Some spines are more visible because they are laterally preserved (on left half of the fruit) while others only show as depressions (on the right half of the fruit). This fruit differs from all other Warman fruits/seeds in its reniform shape and the presence of spines on its surface. This spiny fruit resembles the spiny fruit of extant Caesalpinia bonduc (Linnaeus) Roxburgh but the size of the fossil fruit is much smaller. This fossil fruit also lacks a pedicel, a receptacle, a gynophore and a persistent style. 

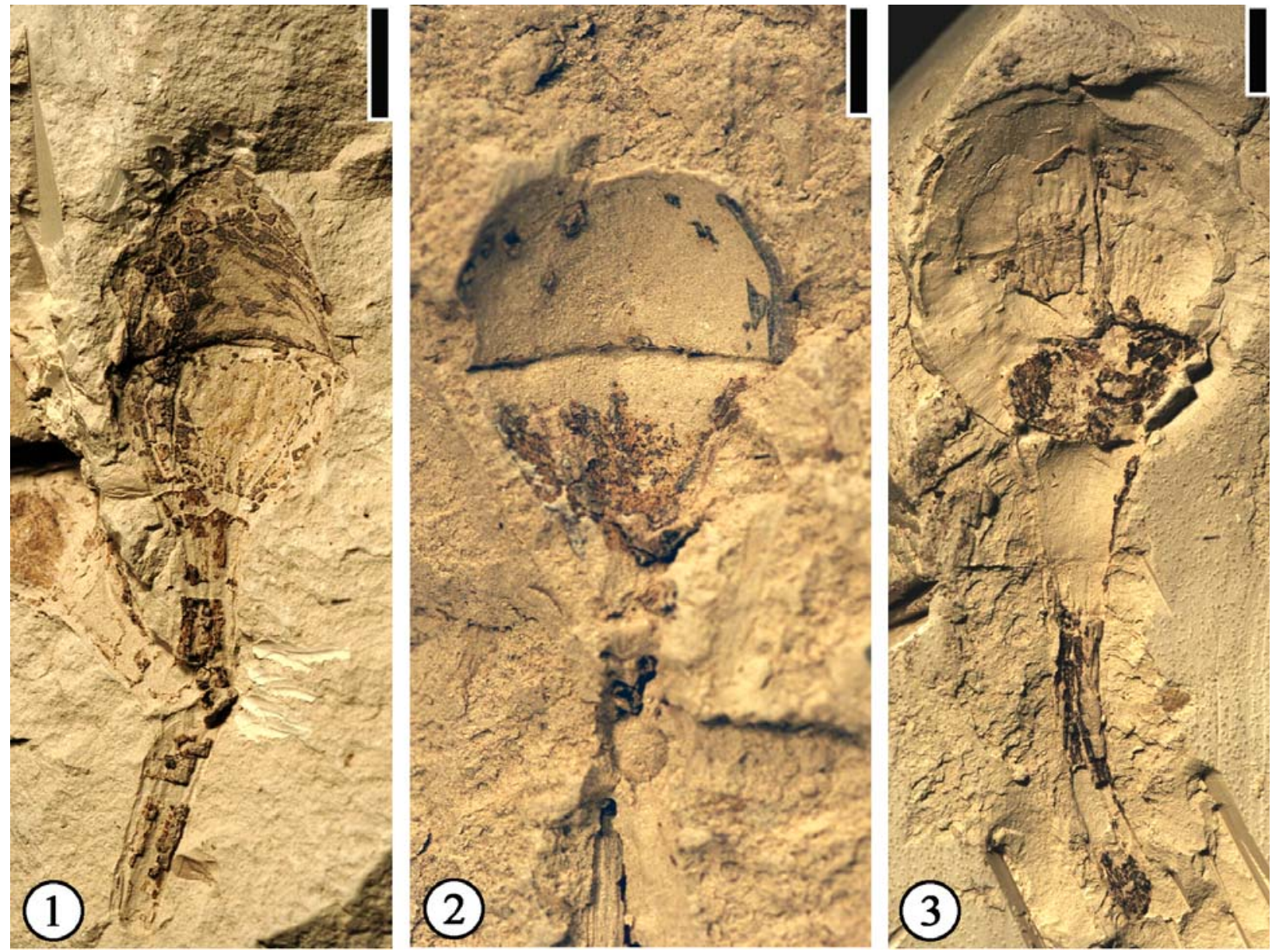

FIGURE 41. Carpolithus collinsi (Berry) comb. nov. 1. UF15815-6894. Showing an elliptic fruit. Scale bar $=4 \mathrm{~mm}$. 2 . UF15826-51487. Showing an orbicular fruit. Scale bar $=2 \mathrm{~mm}$. 3. UF15826-51238. Note longtitudinal striations on the upper fruit body. Scale bar $=4 \mathrm{~mm}$.

"Copaifera" yeguana Berry, 1915

(Figure 46)

1915 Copaifera yeguana Berry, pp. 41-44, fig. 1. 1924 Copaifera yeguana Berry, p. 63, plate X, fig. 4.

1931 Copaifera yeguana Berry, Ball, p. 123, plate 20, fig. 10.

Description. Fruit ca $11 \mathrm{~mm}$ in diameter and seed $7 \mathrm{~mm}$ in diameter. The mesocarp is ca $2 \mathrm{~mm}$ thick. Surface of exocarp smooth. Two protrusions present on the opposite sides of the exocarp.

Number of specimens examined. 1. UF1582651465 (Figure 46).

Discussion. Berry $(1915,1924)$ described two specimens from the Yegua Formation in Angelina County, Texas and assigned them to the modern genus Copaifera. These specimens possibly represent drupes instead of legume pods as described by Berry $(1915,1924)$. The single seed is indicated by the depression in the middle of the fruit. Most fossil fruits and seeds, including several species of legume pods, are greatly compressed and the elevation of seeds is not obvious. The presence of seeds (or ovules) inside the pods is indicated by their outlines (see previous section: Family FABACEAE). On the contrary, specimens described above and by Berry (1924) seem to show obvious elevation for seeds. The high elevation may indicate a stony seed inside the fruit, which is harder to compress. The two protrusions, on the two opposite sides, may represent a persistent style on one end and the pedicel on the other end. Berry (1930, p. 78 , plate 46 , figs. 5,6 ) described two leaflet specimens from the Holly Springs sand, Grable pit, Henry County, Tennessee and assigned them to the modern genus Copaifera, based upon the similarity of leaflet form and venation and the presence of the "Copaifera" fruits (Berry, 1924).

In gross morphology, the specimens described by Berry $(1915,1924)$ are the same as 


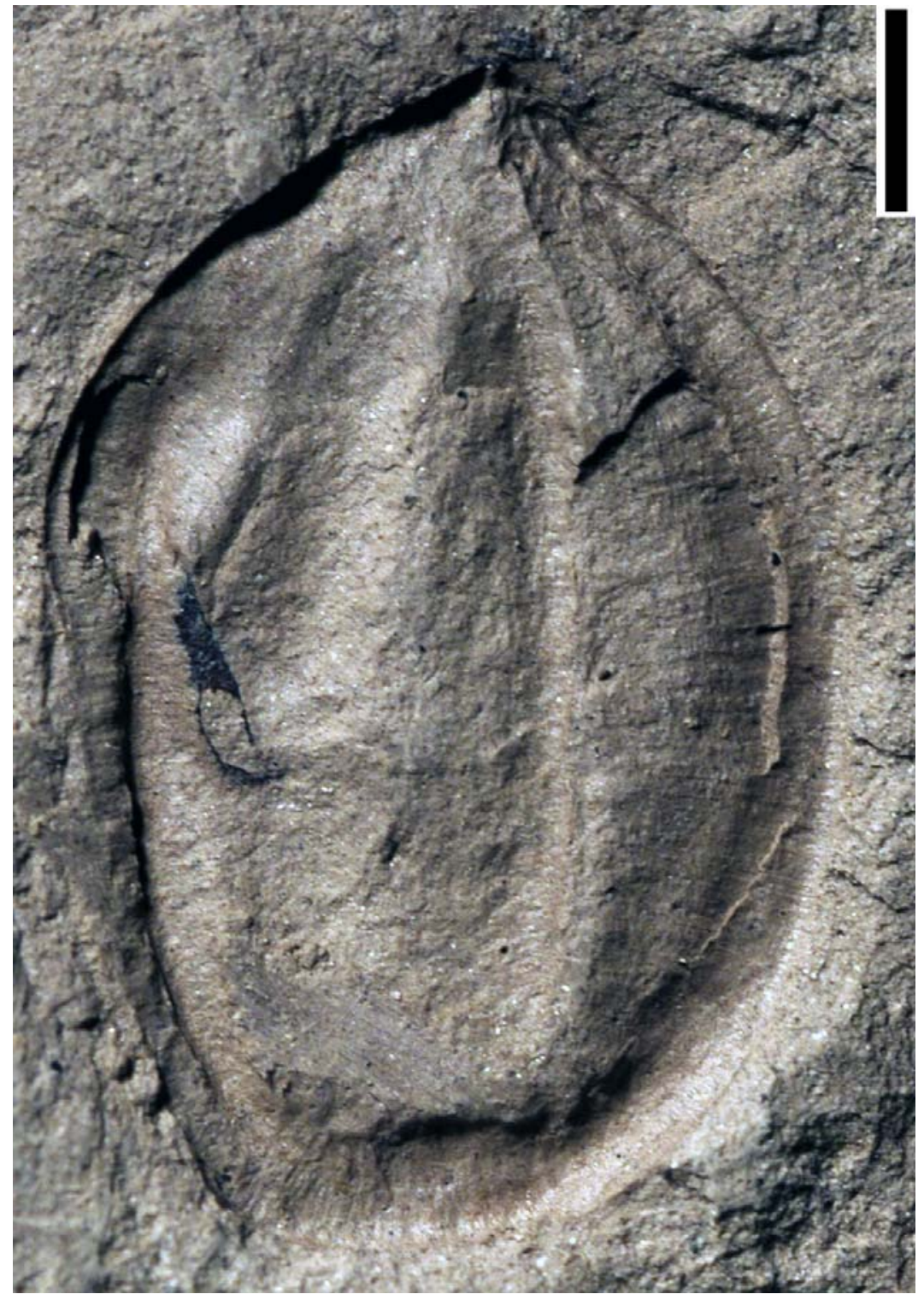

FIGURE 42. Carpolithus complanata (Lesquereux) comb. nov. UF15826-51486. An elliptic seed showing ridges and grooves. Scale bar $=1 \mathrm{~mm}$.

the specimen described here except that the current fruit is a bit smaller than Berry's. We feel that the assignment of these fossil leaflets and fruits needs further validation when well-preserved specimens with more characters are available. We consider that its modern affinity is uncertain.

Genus PALMOCARPON Berry 1930

Palmocarpon wilcoxiana (Berry) comb. nov.

(Figures 47, 48)

1916 Nyssa wilcoxiana, Berry, p. 331, pl. 99, figs. 5-7.

1916 N. eolignitica, Berry, p. 332, pl. 99, fig. 8.

1924 N. wilcoxiana, Berry, p. 89.
1930 Palmocarpon syagrusioides, Berry, p. 56, pl. 8, figs. 5-6.

1930 N. wilcoxiana, Berry, p. 126, pl. 19, figs. 6-8; pl. 39, figs. 8, 9.

1941 N. wilcoxiana, Berry, p. 84.

Description. Endocarp compressions/impressions elliptic to ovate, symmetric or asymmetric, $1.5-2.5 \mathrm{~cm}$ long and $0.9-1.3 \mathrm{~cm}$ wide. Three to eight strong longitudinal ridges, fine longitudinal striations and/or reticulate ornamentation present on the surface. Distal fine projections present, ca 2-5 mm long and $0.1-0.2 \mathrm{~mm}$ wide.

Number of specimens examined. 29. UF1582651232 (Figure 47.1-2); 51400 (Figure 47.3); 51334 (Figure 47.4); 51514 (Figure 47.5); 51459 (Figure 


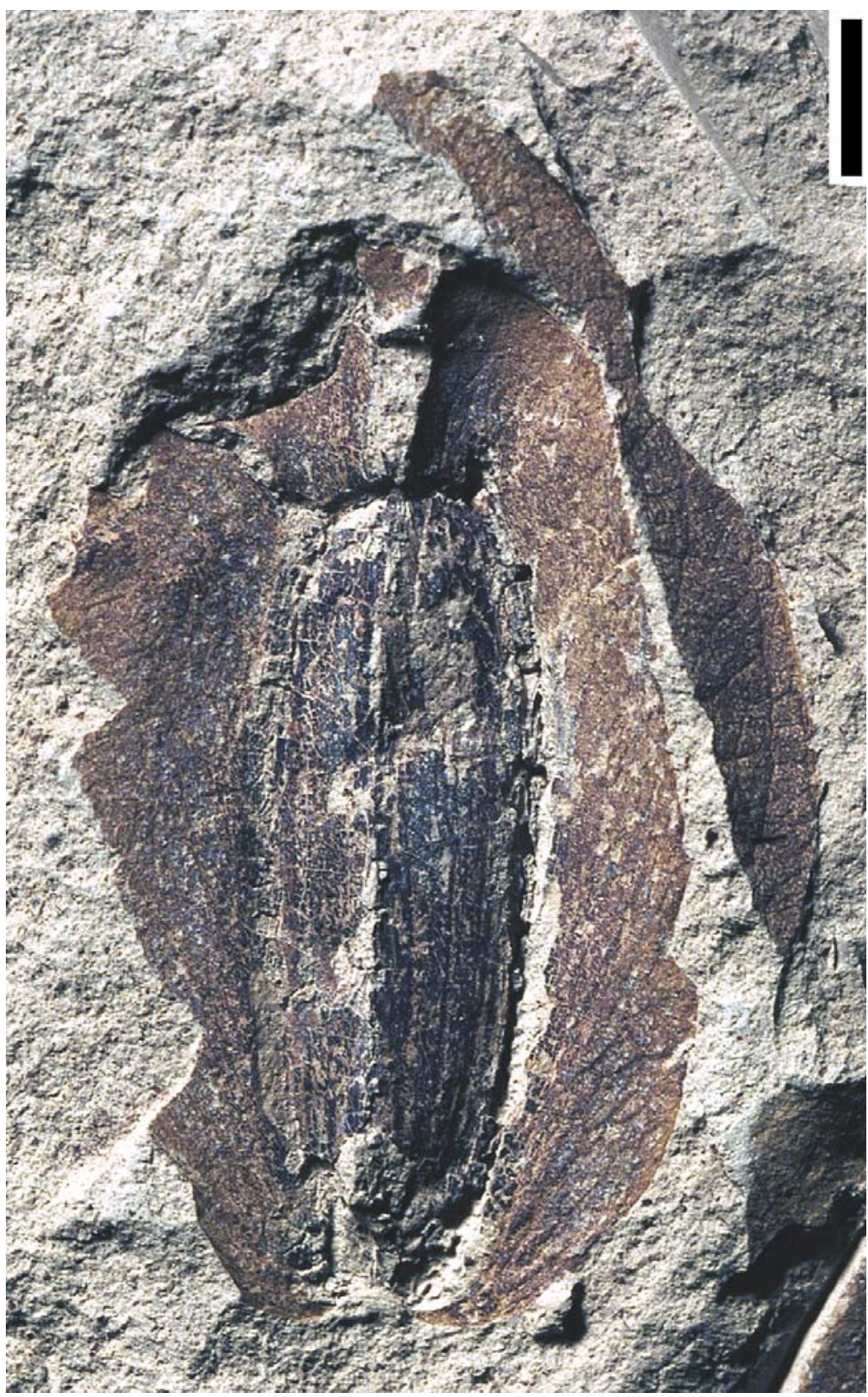

FIGURE 43. Carpolithus prangosoides Berry. UF15826-51403. Showing two lateral wings with reticulate venation, elliptic central body with longitudinal striations and a median ridge. Scale bar $=2 \mathrm{~mm}$.

47.6); 30831 (Figure 48.1-2); 51438 (Figure 48.3); 51279 (Figure 48.4); 51338 (Figure 48.5); 51389 (Figure 48.6).

Discussion. Berry (1916; p. 331, pl. 99, figs. 5-7; p. 332, pl. 99, fig. 8.) first described four impression specimens from Puryear clay pit, Tennessee and assigned three to Nyssa wilcoxiana and one to Nyssa eolignitica. In his following publications, Berry assigned similar specimens to Nyssa wilcoxiana (Berry, 1924, 1930, 1941) and two other speci- mens to Palmocarpon syagrusioides (Berry, 1930). These specimens may represent different preservation modes of the same fruit/seed type at various developmental stages. We propose that they all belong to the same fossil-genus Palmocarpon but available characters do not warrant their assignment to the genus Nyssa or the Palmae. We retain the species epithet wilcoxiana proposed by Berry (1916). 

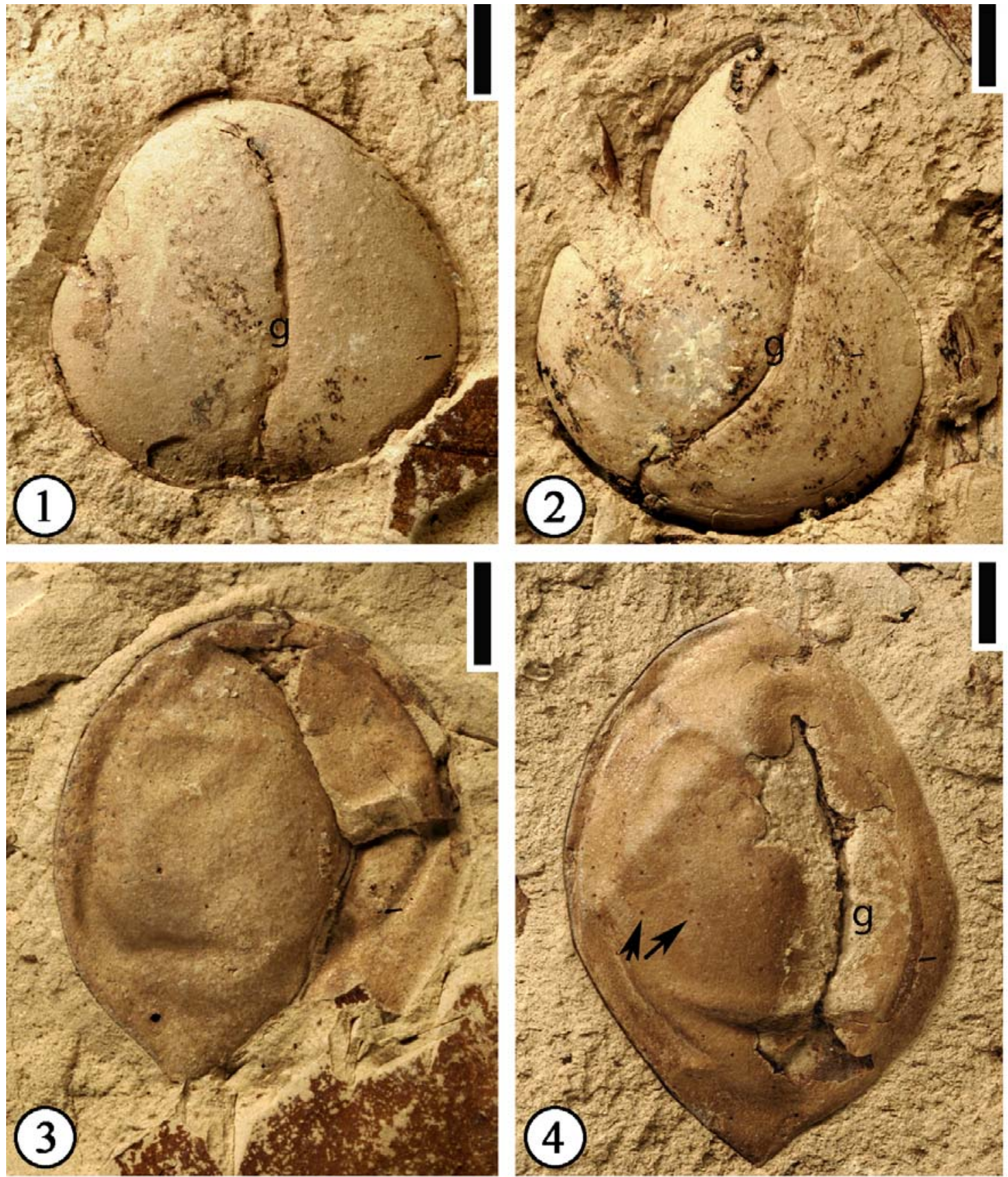

FIGURE 44. Carpolithus sophorites Berry. 1. UF15826-51382. A disseminule with a mostly missing thin wall and a central groove (g). Scale bar $=2 \mathrm{~mm}$. 2. UF15826-51517. A disseminule showing a central groove (g). Scale bar $=2$ $\mathrm{mm}$. 3. UF15826-51545. A disseminule showing folding of a thin wall. Scale bar $=3 \mathrm{~mm}$. 4. UF15826-51288. A disseminule with a groove $(\mathrm{g})$. Note glands (indicated by arrows) on the disseminule wall. Scale bar $=2 \mathrm{~mm}$.

\section{"Sparganium" sp.}

(Figure 49)

1930 Sparganium? sp., Berry, plate 8, fig. 1, p. 54. Description. Globose structures ca $7.0 \mathrm{~mm}$ in diameter, covered with numerous depressions ca $0.5 \mathrm{~mm}$ in diameter. Stalk ca $3 \mathrm{~mm}$ long and $1 \mathrm{~mm}$ wide, covered with trichomes. Triangular projections ca $0.25 \mathrm{~mm}$ long present on the margin.

Number of specimens examined. 2. UF1582651260 (Figure 49.1); 51432 (Figure 49.2-3).

Discussion. Berry (1930, plate 8, fig 1) described a specimen with two globose structures attached to a stalk and assigned it to the extant genus Sparga- 


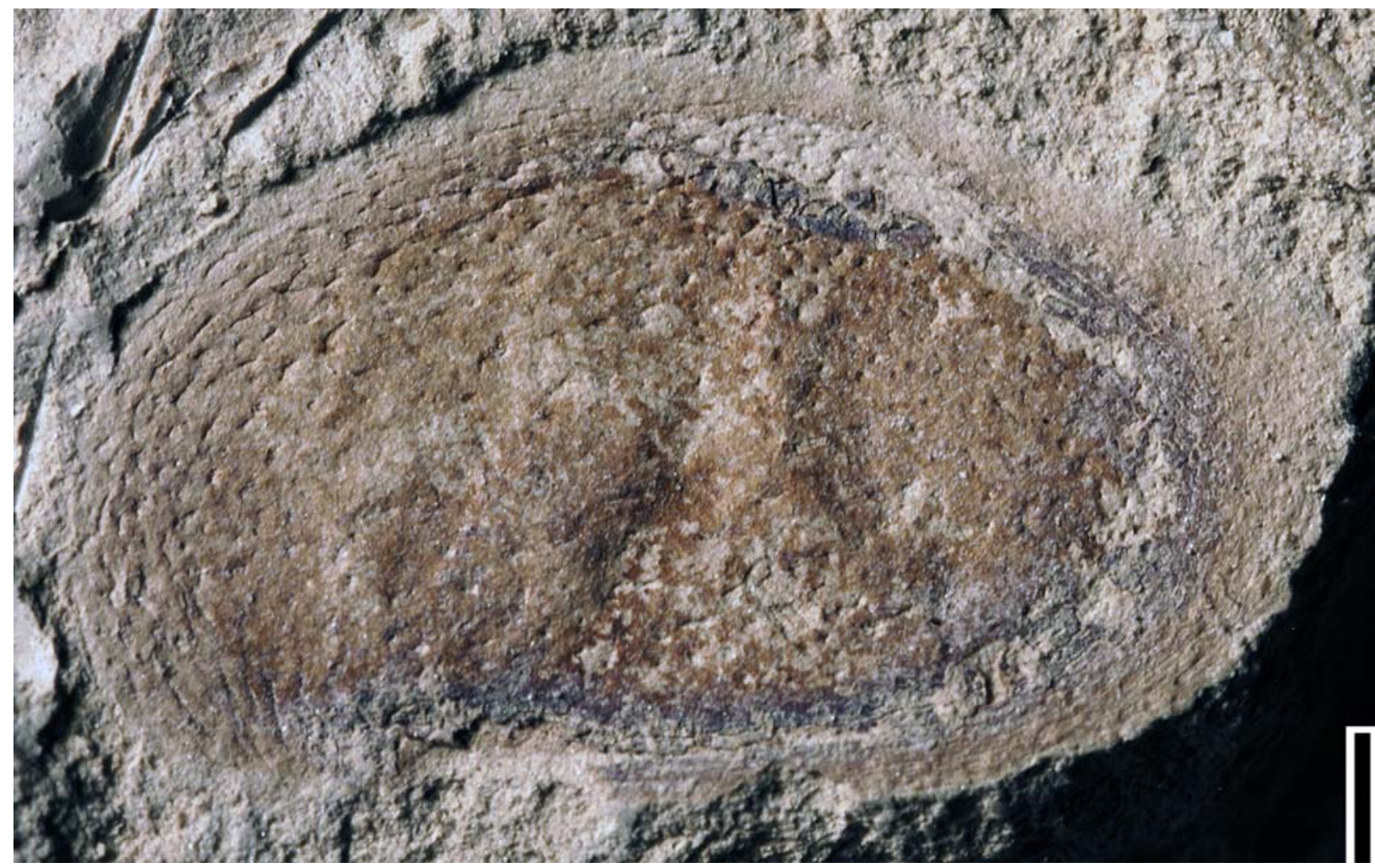

FIGURE 45. Carpolithus warmanensis sp. nov. UF15826-51471. A spiny fruit showing seed outline, laterally compressed spines on the left and vertically compressed spines on the right. Scale bar $=1 \mathrm{~mm}$.

nium, which includes about 20 species of perennial marsh plants in temperate regions of both the Northern and Southern Hemispheres. APG III (2009) places this genus within the family Taphaceae. As mentioned by Berry (1930), some other families (i.e., Pontederiaceae and Alismataceae) produce similar pistillate inflorescences. In addition, it is uncertain if these structures represent pistillate inflorescences or fruits/seeds. Based upon the characters that are currently available, the assignment of these fossils to the extant genus Sparganium is premature.

Although isolated pollen grains are visible over the surface of the inflorescence and the surrounding matrix under the microscope with epifluorescent light, in situ pollen grains are not observed. No specific pattern of distribution of the spines and/ or depressions is observed. These structures may represent fruits or pistillate inflorescences.

\section{Fruit/Seed Type 1 \\ (Figure 50)}

Description. Capsule mold ovate, $11 \mathrm{~mm}$ long and $9 \mathrm{~mm}$ in diameter. Capsule wall thin with longitudinal striations on the inner side. Receptacle ca 1 $\mathrm{mm}$ thick and $4 \mathrm{~mm}$ in diameter. Stalk ca $6 \mathrm{~mm}$ long and $2 \mathrm{~mm}$ in diameter. Seeds compressed ca
$8 \mathrm{~mm}$ long and $3 \mathrm{~mm}$ wide. Sutures on seed present.

Number of specimens examined. 1. UF1582651460 (Figure 50).

Discussion. One part of a specimen containing two seeds represents one-half of a capsule. It is reasonable to assume that there were probably four seeds within this fruit. The capsule is probably in its late developmental stage but it is not yet dehiscent. One seed shows two sutures, one on the dorsal side and one on the ventral side. Based upon the ventral sutures observed on the seeds, the placentation of the ovary is probably central, with a placenta in a central column within a unilocular ovary (free-central placentation).

\section{Fruit/Seed Type 2}

(Figure 51)

Description. Fruit/fruiting heads laterally compressed, $1.5-2.0 \mathrm{~cm}$ long and $2.0-2.8 \mathrm{~cm}$ wide, bearing 6-7 apically split appendages $1-1.5 \mathrm{~cm}$ long and $4 \mathrm{~mm}$ wide. A disc-like receptacle present.

Number of specimens examined. 2. UF1582651227 (Figure 51.1); 51424 (Figure 51.2).

Discussion. These two specimens may represent cupulate receptacles rather than fruiting heads 


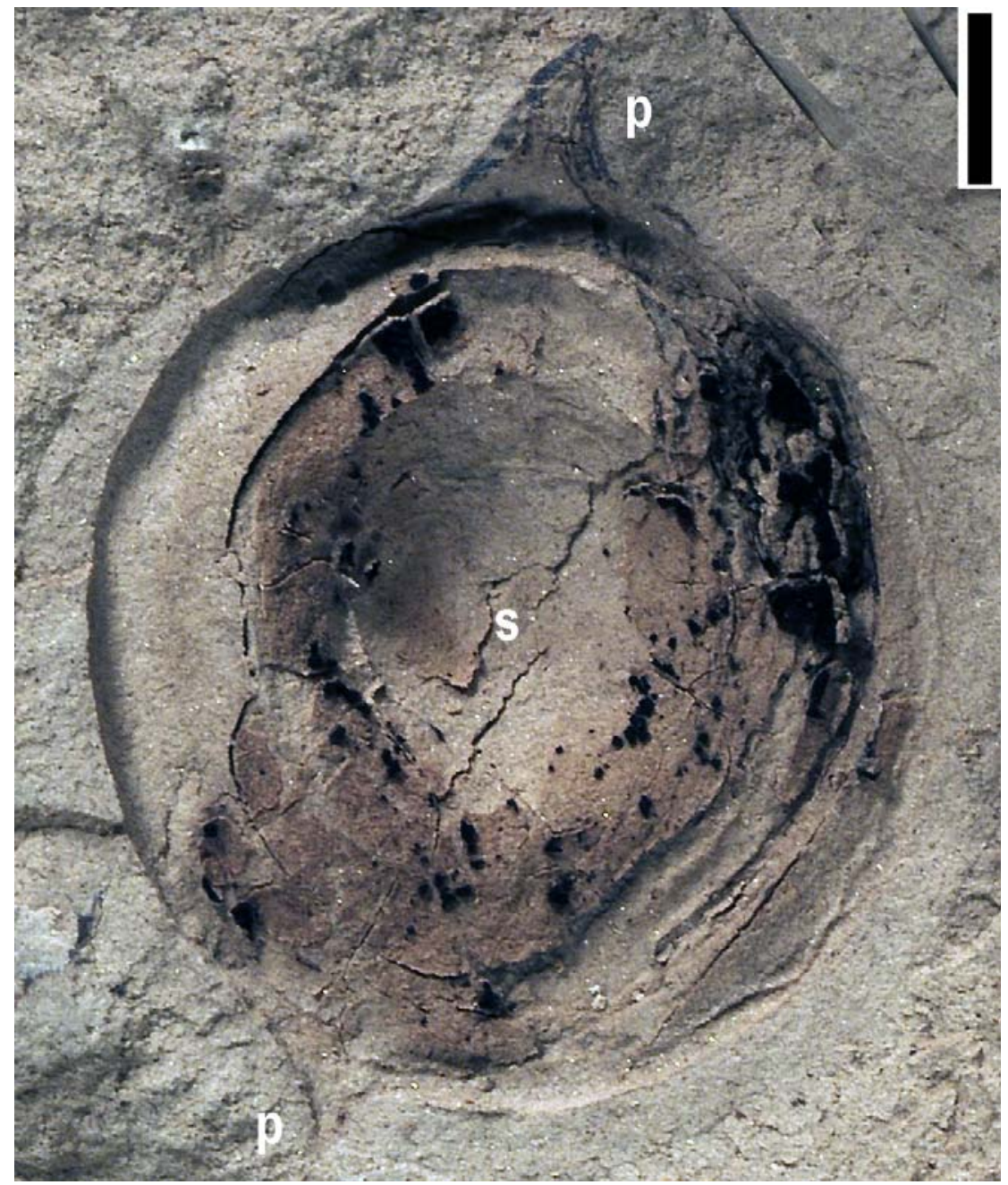

FIGURE 46. "Copaifera" yeguana Berry. UF15826-51465. A drupe-like fruit showing a depression where a presumed stony seed (s) was located and two projections on the exocarp $(p)$. Scale bar $=2 \mathrm{~mm}$.

bearing many dry, dehiscent seeds. If so, it is possible that they represent a member of the Fagaceae with acorns already dispersed. In this case, the appendages are probably elongate cupular scales. Mai (2001, plate 8 , figs. 16-24) described several specimens with similar morphology from the Miocene flora of the Meuro and Rauno sequences in the Lusatica region and assigned them to Quercus sapperi.

\section{Fruit/Seed Type 3 \\ (Figure 52)}

Description. Seed cast $/$ mold ca $1.2 \mathrm{~cm}$ long and 8 $\mathrm{mm}$ wide. Seed coat ca $0.1-0.2 \mathrm{~mm}$ thick with smooth inner surface. Hilum ca $3 \mathrm{~mm}$ in diameter. Number of specimens examined. 3. UF1582651503 (Figure 52.1); 51454 (Figure 52.2); 51466 (Figure 52.3).
Discussion. The thick seed coat is absent on other seed types. The hilum of the seed is represented by a small projection (Figure $52.2,3$ ).

\section{Fruit/Seed Type 4 \\ (Figure 53)}

Description. Fruit elliptic, $5 \mathrm{~mm}$ long and $2.5 \mathrm{~mm}$ wide with seed positioned at the lower half, ca 3 $\mathrm{mm}$ long and $1 \mathrm{~mm}$ wide. Distal wing encircling seed body. Wing ca $1.4 \mathrm{~mm}$ wide at the distal portion and $1 \mathrm{~mm}$ at the middle portion. A central groove is present on the seed body.

Number of specimens examined. 1. UF1582651415 (Figure 53).

Discussion. The specimen represents a winged fruit or seed. The central groove on the seed body may represent the junction of the two cotyledons.

Fruit/Seed Type 5

(Figure 54) 

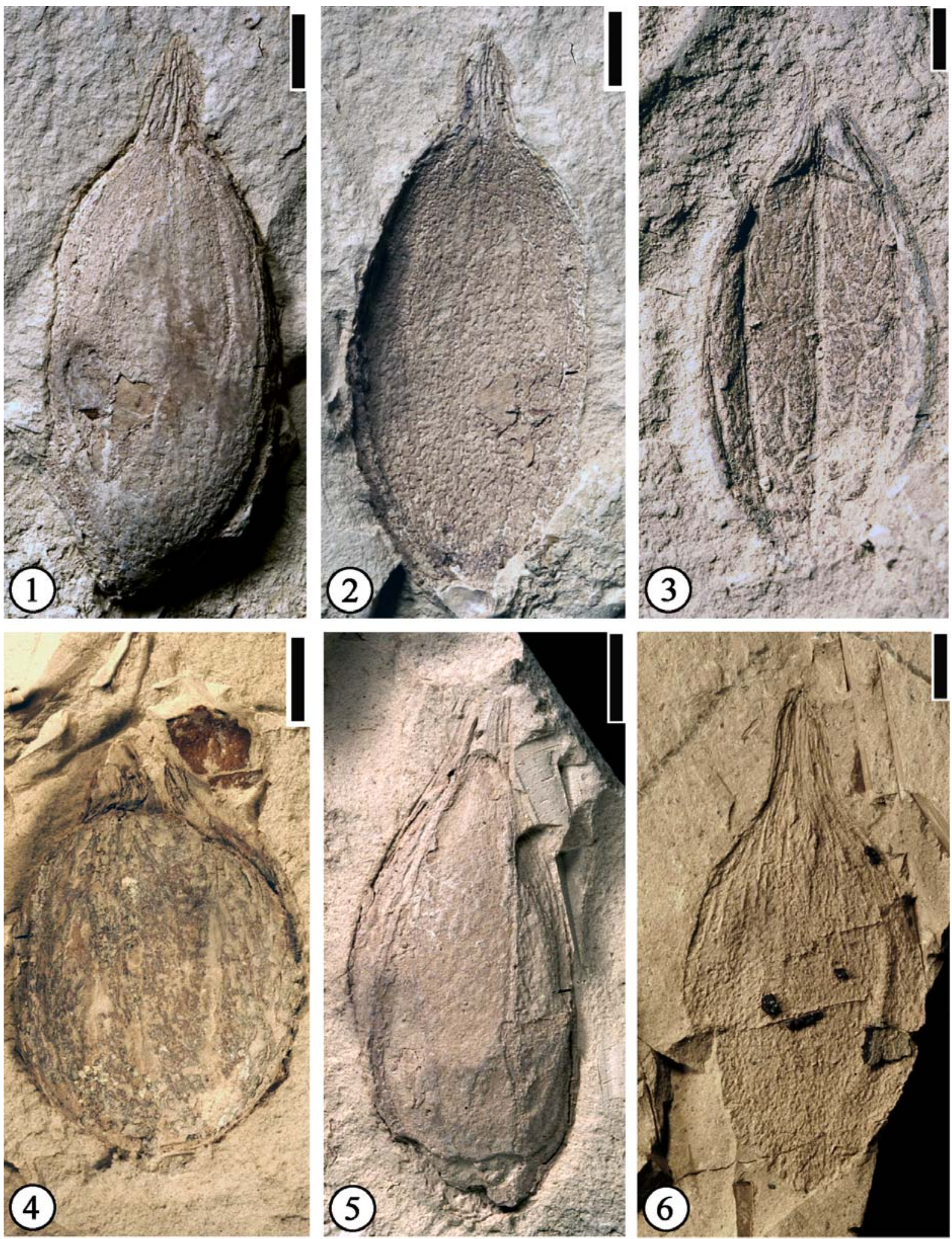

FIGURE 47. Palmocarpon wilcoxiana (Berry) comb. nov. 1. UF15826-51232. Mold of an elliptic fruit. Scale bar $=3$ $\mathrm{mm}$. 2. Counterpart of Figure 47.1 showing impression of an elliptic fruit. Scale bar $=3 \mathrm{~mm}$. 3. UF15826-51400. A fruit showing longitudinal ridges and reticulate ornamentation. Note fine projections at the distal end. Scale bar $=2 \mathrm{~mm} .4$. UF15826-51334. An ovate fruit. Scale bar $=3 \mathrm{~mm}$. 5. UF15826-51514. A fruit showing two strong longitudinal grooves. Scale bar $=3 \mathrm{~mm}$. 6. UF15826-51459. A fruit showing longitudinal striations. Scale bar $=3 \mathrm{~mm}$. 

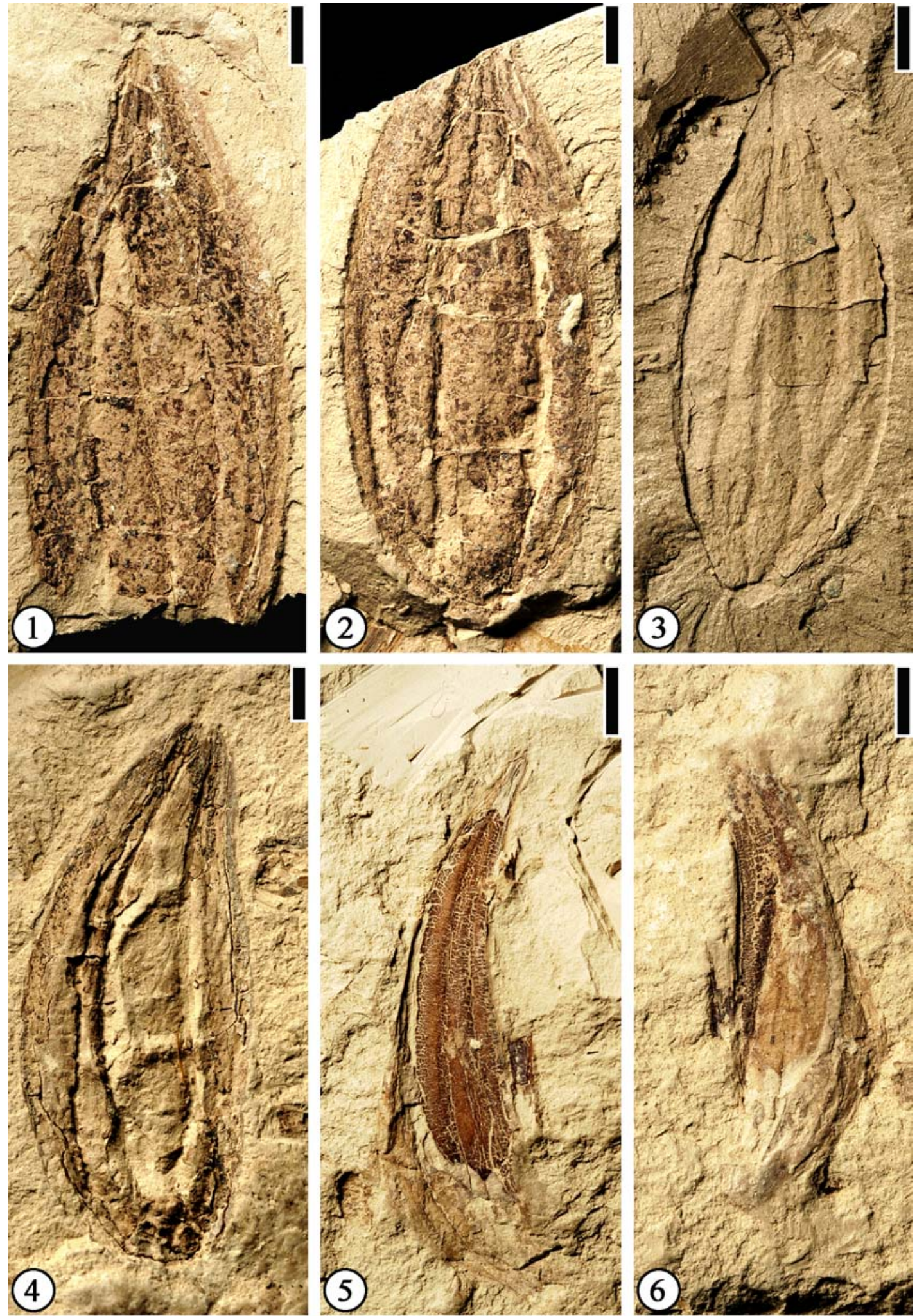

FIGURE 48. Palmocarpon wilcoxiana (Berry) comb. nov. 1, 2. UF15826-30831. Part and counterpart of a specimen showing longitudinal ridges and grooves. Scale bar $=2 \mathrm{~mm}$. 3. UF15826-15438. An impression showing longitudinal ridges. Scale bar $=3 \mathrm{~mm}$. 4. UF15826-51279. An asymmetric fruit. Scale bar $=2 \mathrm{~mm}$. 5. UF15826-51338. A segment of a possibly dehisced capsule. Scale bar $=3 \mathrm{~mm} .6$. UF15826-15389. Another dehisced capsule. Scale bar $=3 \mathrm{~mm}$. 

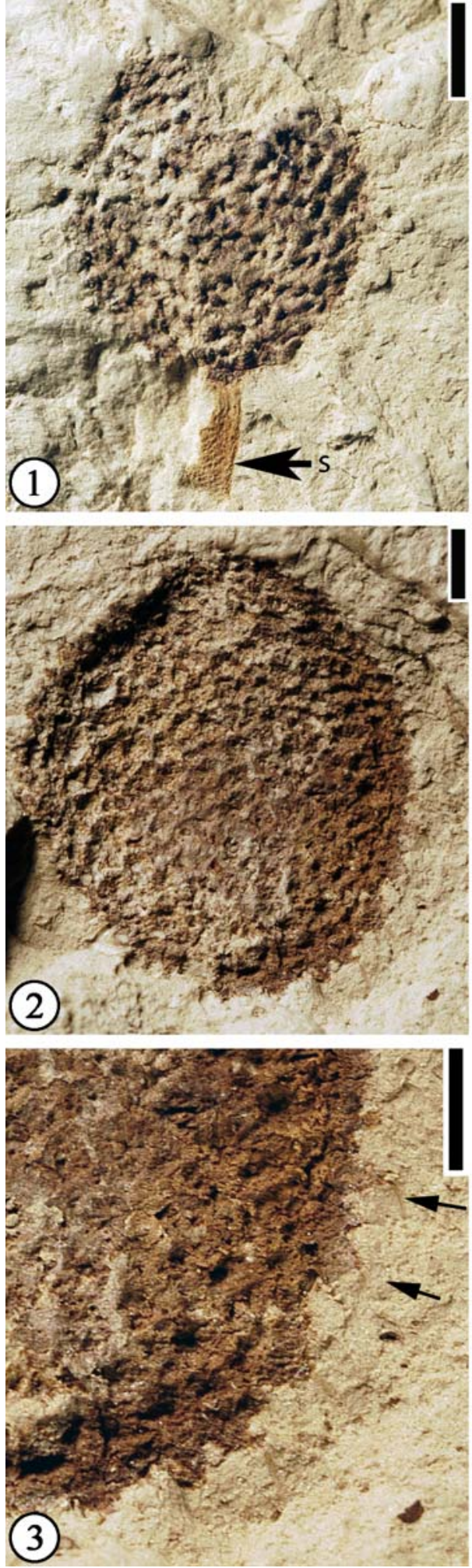

FIGURE 49. Sparganium sp. 1. UF15826-51260. Showing surface depressions and a stalk (s). Scale bar $=2$ $\mathrm{mm}$. 2. UF15826-51432. Showing surface depressions and projections. Scale bar $=1 \mathrm{~mm}$. 3. Enlargement of Figure 49.2. Arrows indicate surface projections. Scale bar $=1 \mathrm{~mm}$
Description. Fruits orbiculate, ca 10-14 mm long and $8-10 \mathrm{~mm}$ wide. Stalk ca $1.5 \mathrm{~cm}$ long and $1 \mathrm{~mm}$ wide. Thin, irregular, and longitudinally oriented striations present on the fruit surface.

Number of specimens examined. 2. UF1582651425 (Figure 54.1-2); 51427 (Figure 54.3).

Discussion. These specimens may represent legume pods. Figure 45.1 and Figure 45.2 show two valves that have split open. If these specimens represent legume pods, it seems that there is only one seed in each pod.

\section{PLANT INSERTAE SEDIS \\ Cone-like structure}

(Figure 55)

Description. Cone-like structure ovate, $14 \mathrm{~mm}$ long and $8 \mathrm{~mm}$ wide. Stem ca $22 \mathrm{~mm}$ long and 2.5 $\mathrm{mm}$ wide with four nodes and five internodes. Each internode ca 3.5-5.0 mm long with 4-6 longitudinal grooves ca $0.5 \mathrm{~mm}$ in width. Finer striations present on these longitudinal grooves. Each node ca $0.2 \mathrm{~mm}$ in length.

Number of specimens examined. 1. UF1582651391 (Figure 55).

Discussion. The specimen superficially resembles Equisetum cones, but the absence of scale-like leaves on the nodes and the absence of sporangia on the terminal structure suggest that it is not related to Equisetum. This specimen could also represent a vegetative shoot bearing a terminal bud.

\section{DISCUSSION}

This report represents the first comprehensive presentation of the plant reproductive materials from a single locality from the middle Eocene Claiborne Group. The results provide data helpful for understanding angiosperm diversity during the Eocene from a different perspective. Detailed studies of individual taxa based upon multiple organ types are more reliable in assessing the systematics and diversity of fossil plants, but these types of studies (for example, Manchester, 1986; Boucher et al., 2003; Manchester et al., 2006; Manchester and Hickey, 2007) are rare since different organs of plants tend to be detached and dispersed before preservation. As noted by Dilcher and Lott (2005) when studying the fossil leaf flora from the Powers clay pit, Tennessee, even research based upon a single organ type, i.e., leaves, is usually labor intensive since it requires comprehensive comparisons with both fossil and living taxa. This is also true when one studies plant reproductive materials; while this type of research is continuing and is 

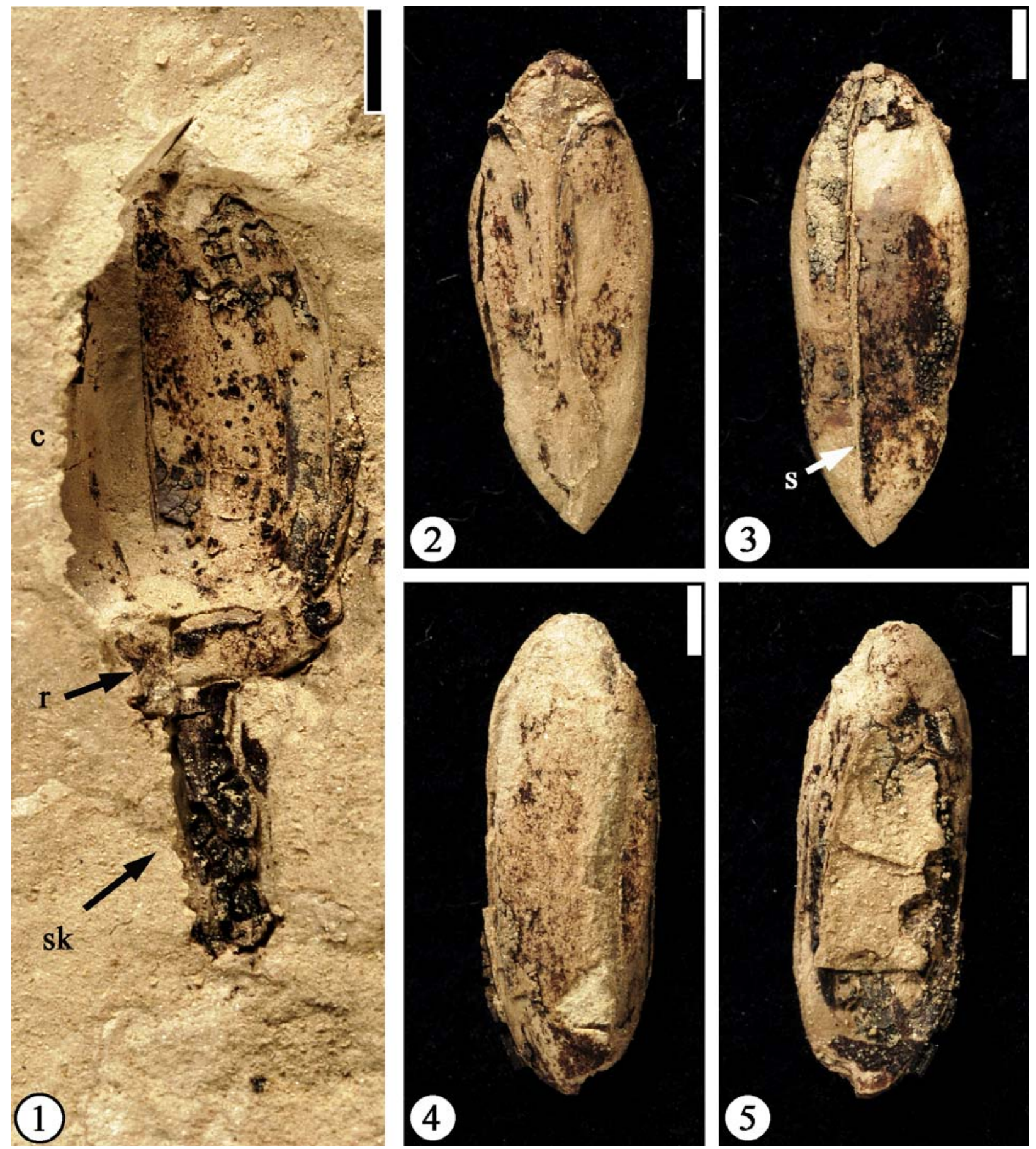

FIGURE 50. Fruit/Seed Type 1. 1. UF15826-51460. A capsule (c) with seeds removed. Note the receptacle ( $r$ ) and the stalk (sk). Scale bar $=2 \mathrm{~mm}$. 2, 3. Opposite sides of one seed removed from the capsule in Figure 50.1. Note the suture (s) on the seed. Scale bar $=1 \mathrm{~mm} .4,5$. Opposite sides of the second seed removed from the capsule in Figure 50.1. Scale bar $=1 \mathrm{~mm}$. 

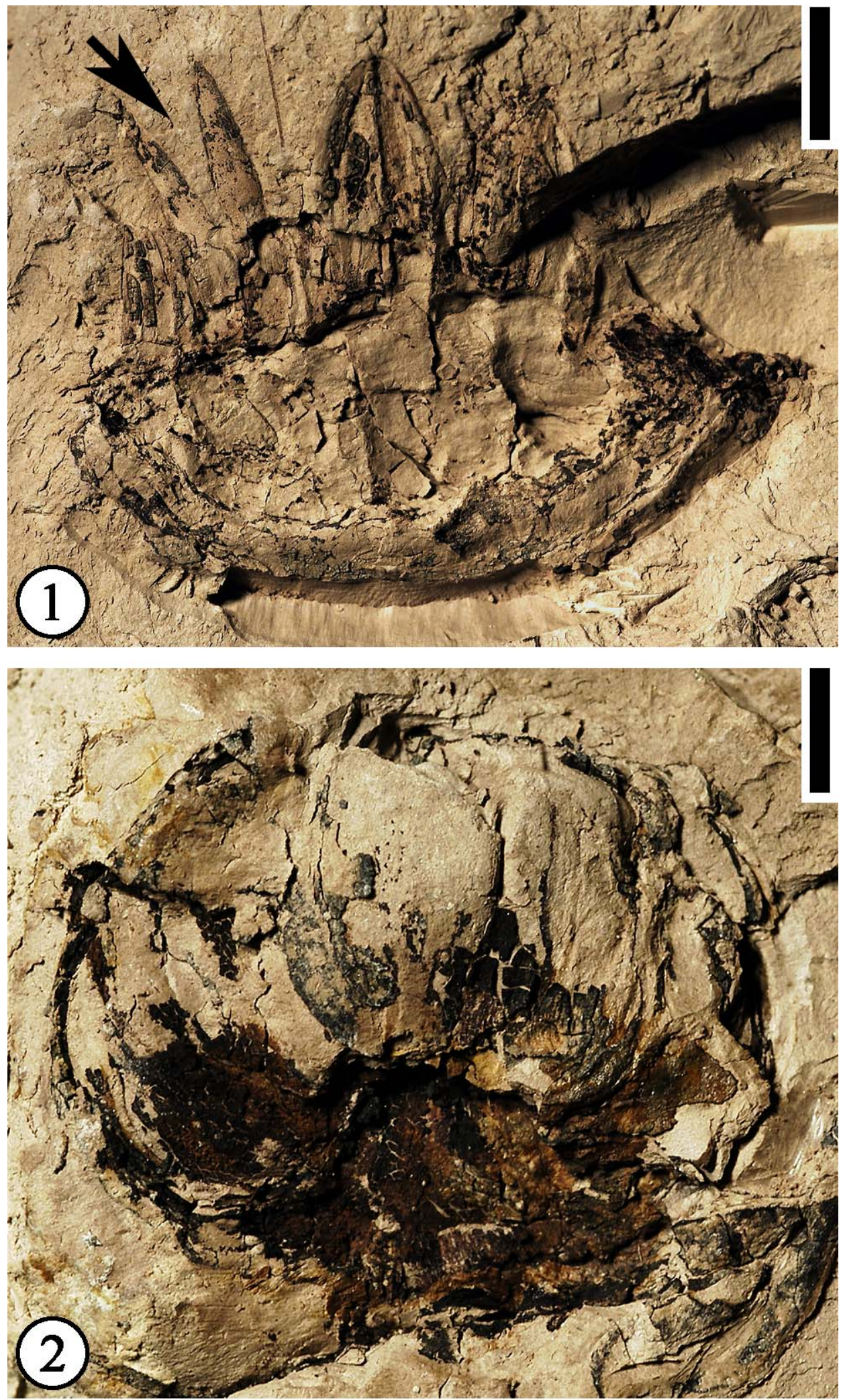

FIGURE 51. Fruit/Seed Type 2. 1. UF15826-51227. A laterally compressed receptacle and its appendages. Note one apically split appendage (indicated by arrow). Scale bar $=5 \mathrm{~mm}$. 2. UF15826-51424. Basal view of a receptacle and its appendages. Scale bar $=3 \mathrm{~mm}$. 

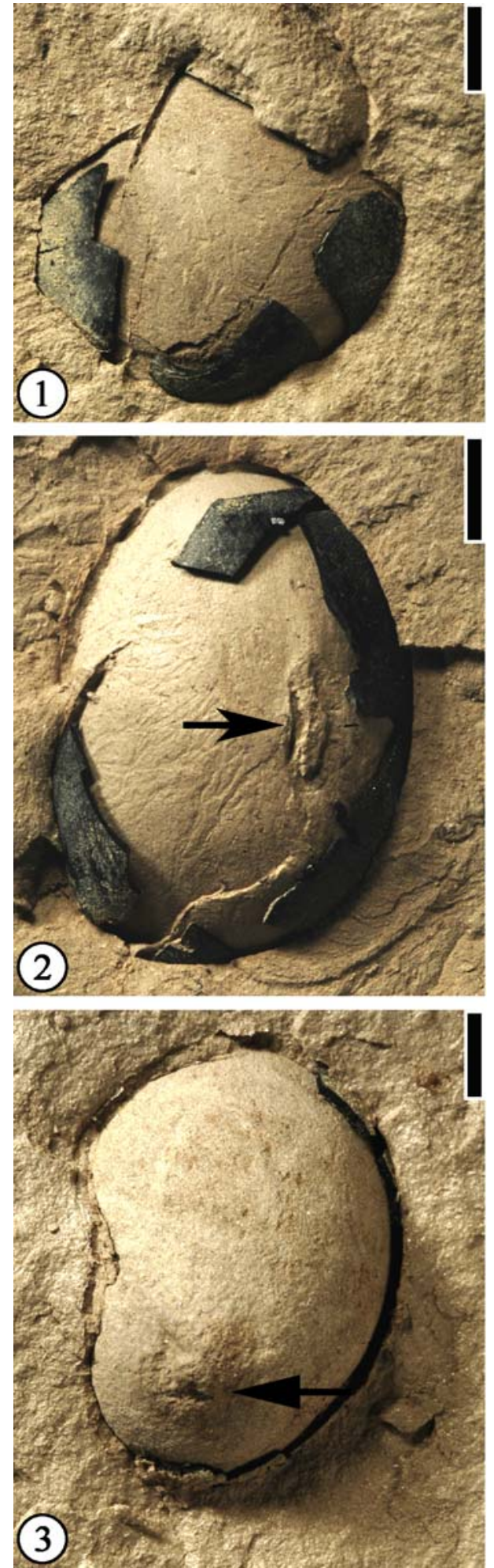

FIGURE 52. Fruit/Seed Type 3. All scale bars equal 2 $\mathrm{mm}$. 1. UF15826-51503. Showing a thick seed coat and a smooth inner surface. 2. UF15826-51454. Showing the position of hilum (indicated by arrow). 3. F1582651466. Showing the position of hilum (indicated by arrow). included here for those taxa already studied we feel that the unique floristic nature of the individual localities of the middle Eocene is also of primary interest and should be presented separately, locality by locality.

Potter and Dilcher (1980) proposed that different clay pits from which fossil plants have been collected are of a different age. While they may all be of middle Eocene, each clay pit may represent a short (500 to 1500 years) and/or slightly different segment of time because oxbow lakes on a flood plain are recognized as short-term events when viewed against geological time (Crisman and Whitehead, 1975). The only way we can understand the change of vegetation through the middle Eocene of southeastern United States is to have detailed floristic information from all localities. Based upon their geomorphic position and vertical distribution in the flood plain, Potter and Dilcher (1980) proposed a sequence of the relative ages of the clay pits (localities), with the Warman clay pit being the second oldest. This approximation of the depositional sequence serves as a basis for detailed evolutionary studies between individual localities.

Taxonomically, the Warman clay pit (UF15826) is the most diverse in reproductive materials among all localities available for examination at the Paleobotany and Palynology collection at the Florida Museum of Natural History, Gainesville, Florida. Of the 600 specimens of reproductive materials examined here (Table 1), 250 identifiable specimens are classified and assigned to a total of 61 fossil-species and morphotypes. This number includes taxa that are from the Warman clay pit and were previously reported elsewhere (Zavada and Crepet, 1981; Crepet and Daghlian, 1982; Taylor and Crepet, 1987). Potter and Dilcher (1980) suggested that the whole series of clay lenses of the Claiborne Group in Henry County, Tennessee represents a short geologic time span. The Warman clay pit includes several clay lenses that cover a relatively larger area and longer time span than neighboring localities (see Figure 8.5 of Potter and Dilcher, 1980). This may explain the relatively high diversity of reproductive materials at the Warman clay pit locality. Other localities that cover an equal or lager area and possibly a longer time span are the Gleason area locality (UF15811), the Cottage Grove area locality (UF15812), and the Liberty Church area locality (UF15813). Unfortunately, the size of the collections from these localities is too small to make reasonable comparisons of their levels of diversity of 


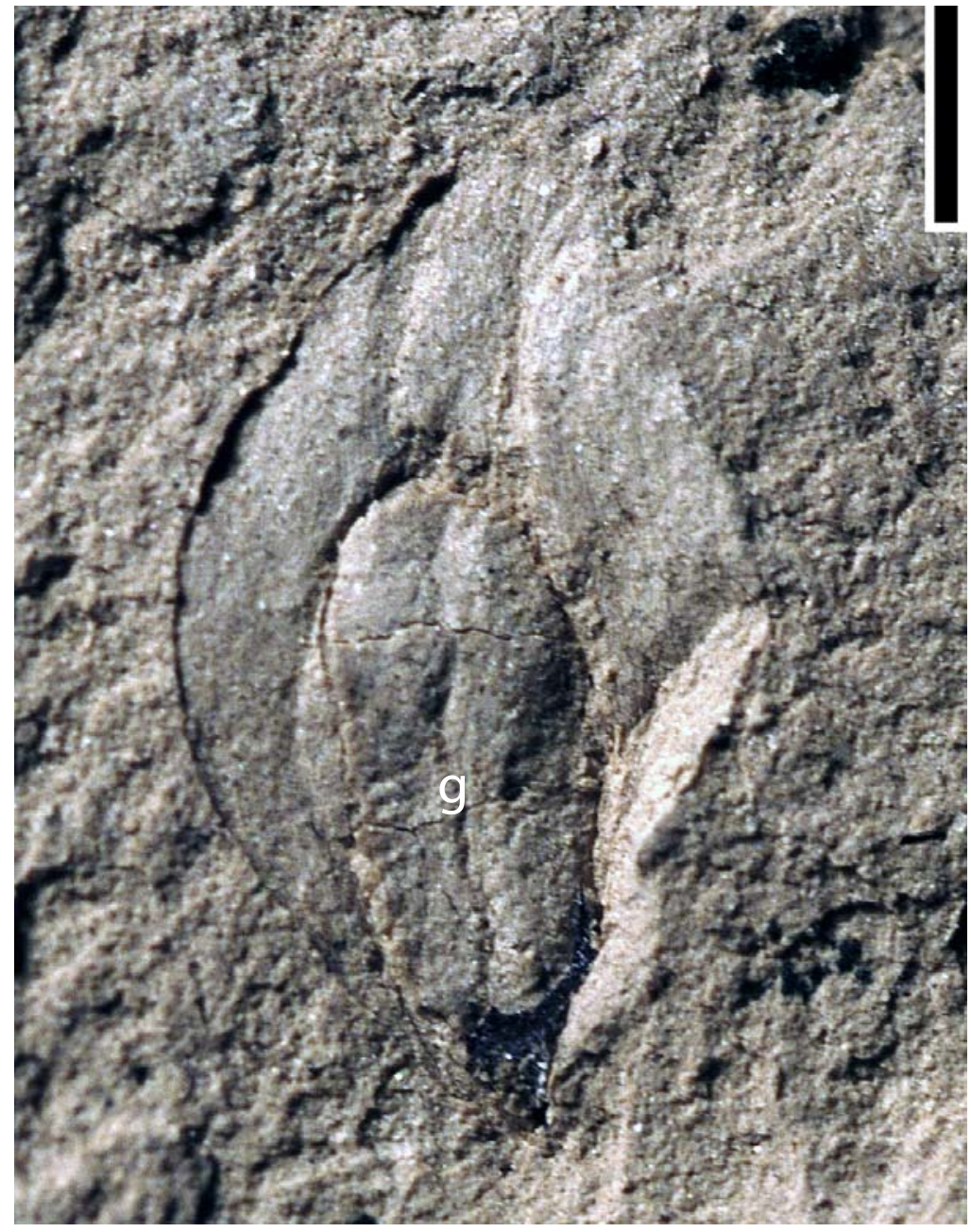

FIGURE 53. Fruit/Seed Type 4. UF15826-51415. Showing an elliptic seed with a surrounding wing. Note the central groove $(\mathrm{g})$ which may be the junction of the two cotyledons. Scale bar $=1 \mathrm{~mm}$.

reproductive materials with that of the Warman clay pit locality.

Thirty-six species $(60 \%)$ are assigned to 16 modern families, including Altingiaceae, Annonaceae, Araceae, Araliaceae, Bignoniaceae, Euphorbiaceae, Fabaceae, Fagaceae, Hamamelidaceae, Juglandaceae, Lauraceae, Magnoliaceae, Malpighiaceae, Moraceae, Oleaceae, and Theaceae. Of these assignments, some of them are done with more confidence because of the extensive research in comparison with modern fruits and seeds (See Herendeen, 1992 for example). Others are tentative assignments to taxa already known from leaves but only a limited number of specimens with limited characters are available and less thorough comparative work with possible modern representatives. The modern affinities of the other recognized species and morphotypes (40\%) are uncertain due to the lack of diagnostic characters or unfamiliar morphology in comparison with extant fruits and seeds.

Legumes are the most diverse group from the Warman clay pit locality. About $20 \%$ of the species and morphotypes are assigned to the Fabaceae. Following legumes are Theaceae, Juglandaceae, Fagaceae, and Annonaceae. Other families only have one or two representatives. Legume leaflets are also the most abundant leaf morphotypes in the flora. Lauraceous leaves are also very abundant. Berry (1916) recognized the same abundance that is reflected in the flora of the American tropics today.

Many other types of reproductive structures have been reported from other middle Eocene Claiborne localities based upon published papers and the collection stored at the Florida Museum of Natural History, but they are not known from the Warman clay pit (e.g., Dilcher and Manchester, 

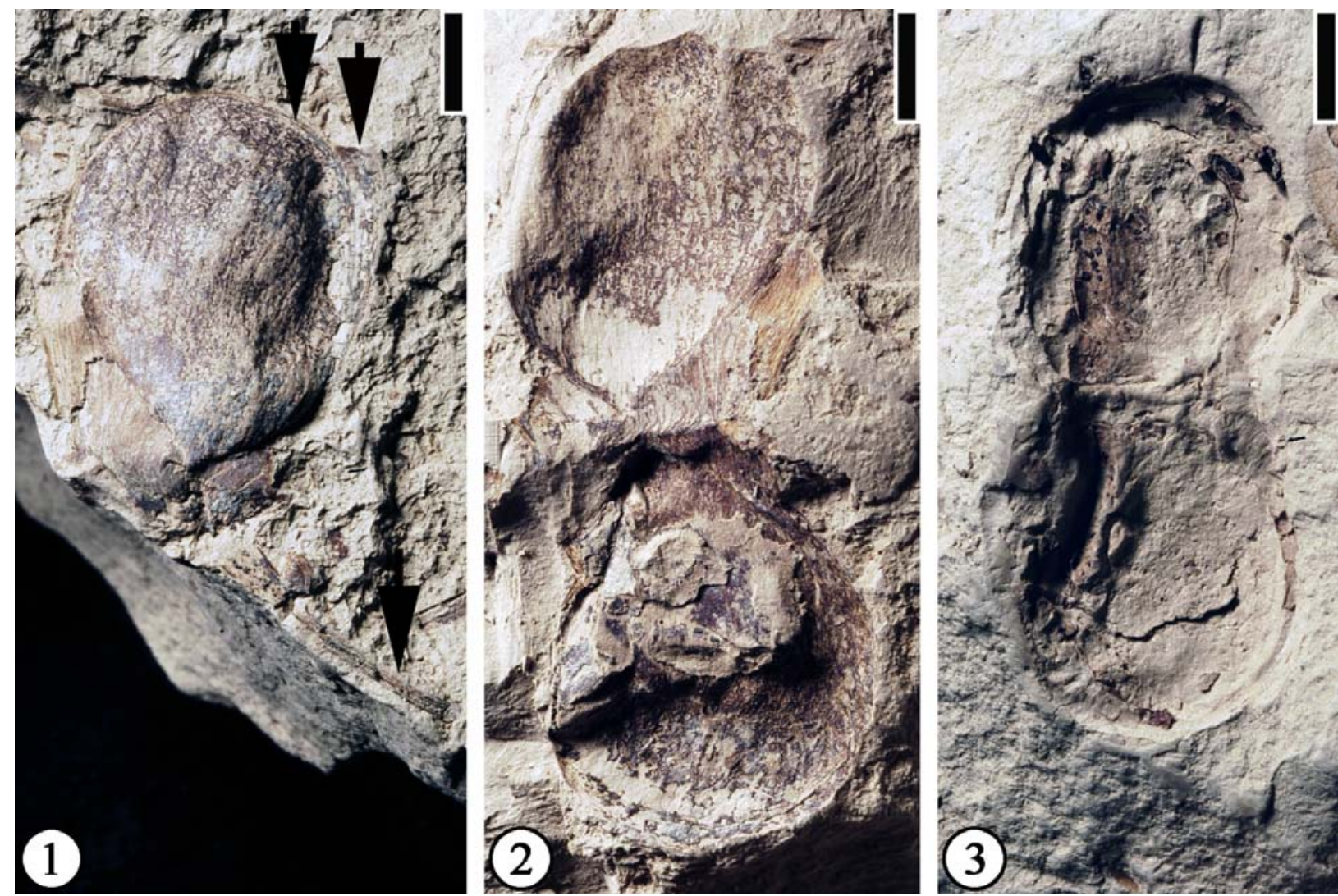

FIGURE 54. Fruit/Seed Type 5. All bars equal $3 \mathrm{~mm}$. 1. UF15826-51425. A fruit with two valves (indicated by top two arrows) and stalk (indicated by bottom arrow). 2. Counterpart of Figure 54.1 showing two fruits.

3. UF15826-51427. Showing two fruits.

1986; Table 2). Grote (1989) suggested that there are at least 78 types of fruits and seeds (other than Theaceae) that can be recognized from other western Kentucky, western Tennessee, and northern Mississippi clay pits of the middle Eocene Claiborne Group. He investigated morphology and anatomy of specimens belonging to five genera assigned to extant families and one genus with unknown affinity and compared them with recent fruits and seeds. These families include Arecaceae, Hamamelidaceae, Magnoliaceae, Moraceae, and Sapotaceae. It should not be a surprise if specimens belonging to any of these families are found in future fieldwork at the Warman clay pit locality.

The level of diversity of angiosperms from some localities based upon reproductive materials seems to be consistent with that based upon leaves. The total number of species and morphotypes from the Warman clay pit is close to the total number of 61 leaf morphotypes recognized from the same locality by Sun (1989). Dilcher and Lott (2005) recognized 26 leaf species and morphotypes from the Powers clay pit, Tennessee, which is $400 \mathrm{~m}$ south of the Warman clay pit. Preliminary examination of the reproductive materials from the Powers clay pit indicates there are approximately 30 morphotypes. At other localities (i.e., Dawson clay pit and Wilbank clay pit, Tennessee), the level of diversity of reproductive materials seems to be lower than that of leaves. This discrepancy may be the result of the amount of specimens collected, time difference (collected from different stratigraphic levels), or the morphological plasticity of leaves.

\section{ACKNOWLEDGMENTS}

We thank numerous friends, colleagues, and students who have helped collect specimens from the Warman clay pit during the past 50 years, Franklin Industries/H.C. Spinks Clay Company, Tennessee, for access to the clay pit, T.A. Lott and S.R. Manchester for their valuable review comments and suggestions on the first draft of the manuscript, S.R. Manchester for his encouragement during the project and for sharing images of E.W. Berry's type specimens stored at the National 


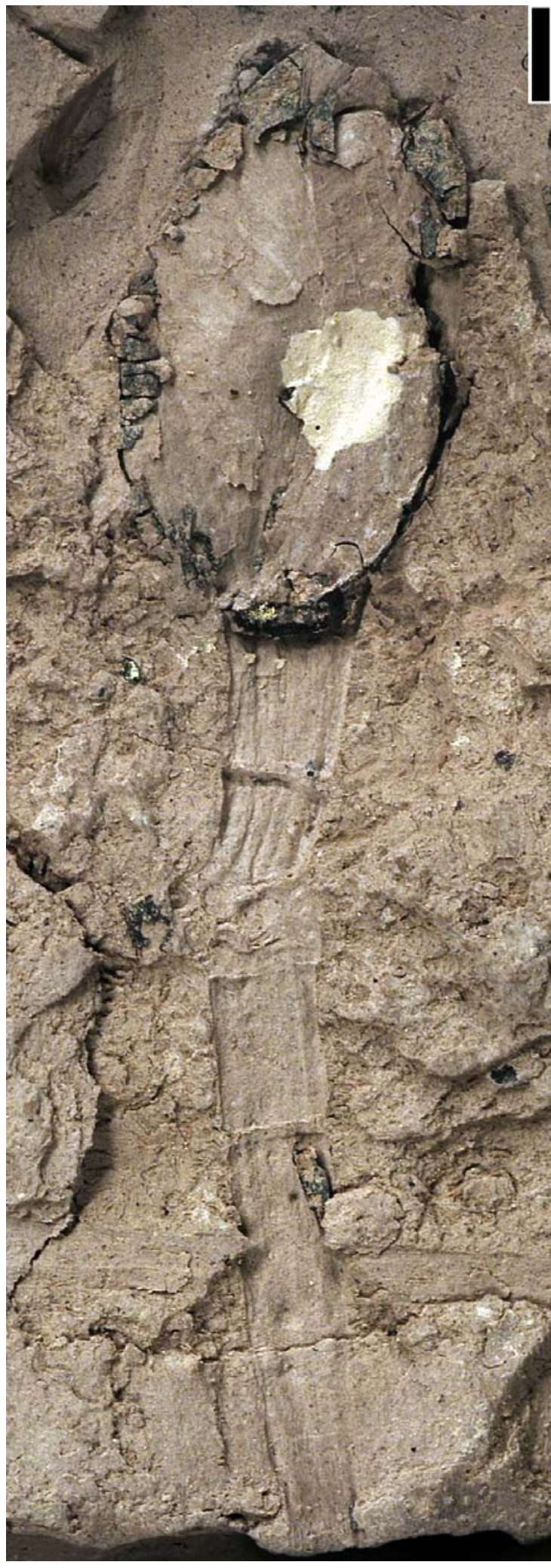

FIGURE 55. Equisetum? sp. UF15826-51391. Showing a cone-like structure and a peduncle with nodes and internodes. Note longitudinal ridges on the internodes. Scale bar $=2 \mathrm{~mm}$.
Museum of Natural History, and Y. (Christopher) Liu and three other anonymous reviewers for their helpful review comments.

\section{REFERENCES}

Afzelius, A. and Brown, R. 1826. Observations on the structure and affinities of the more remarkable plants collected by the late Walter Oudney, M.D., and Major Denham, and Captain Clapperton, in the years 1822, 1823, and 1824, during their expedition to explore Central Africa. T. Davison, London.

Angiosperm Phylogeny Group III (APG III). 2009. An update of the Angiosperm Phylogeny Group classification for the orders and families of flowering plants: APG III. Botanical Journal of the Linnaean Society, 161:105-121.

Ball, O.M. 1931. A contribution to the Paleobotany of the Eocene of Texas. Bulletin of the Agricultural and Mechanical College of Texas, Fourth Series, 2:1173.

Bentham, G. 1837. Commentationes de Leguminosarum Generibus. Annaler des Weiner Museums der Naturgeschichte, 2:63-65.

Berry, E.W. 1914. The affinities and distribution of the lower Eocene flora of southeastern North America. Proceedings of the American Philosophical Society, 53:129-250.

Berry, E.W. 1915. A species of Copaifera from the Texas Eocene. Torreya, 15:41-44.

Berry, E.W. 1916. The Lower Eocene floras of southeastern North America. USGS Professional Paper, 91:1481.

Berry, E.W. 1922. Additions to the flora of the Wilcox Group. USGS Professional Paper, 131A:1-21.

Berry, E.W. 1924. The Middle and Upper Eocene floras of Southeastern North America. USGS Professional Paper, 92:1-206.

Berry, E.W. 1926. Terminalia in the lower Eocene of southeastern North America. Bulletin of the Torrey Botanical Club, 53:59-65.

Berry, E.W. 1927. A new type of caddis case from the lower Eocene of Tennessee. Proceedings of the United States National Museum, 71:1-4.

Berry, E.W. 1930. Revision of the lower Eocene Wilcox flora of the southeastern States with descriptions of new species, chiefly from Tennessee and Kentucky. USGS Professional Paper, 156:1-144.

Berry, E.W. 1937. Tertiary floras of eastern North America. Botanical Review, 3:30-46.

Berry, E.W. 1941. Additions to the Wilcox Flora from Kentucky and Texas. USGS Professional Paper, 193:83-99.

Bogle, A.L. 1986. The floral morphology and vascular anatomy of the Hamamelidaceae: subfamily Liquidambaroideae, Annals of the Missouri Botanical Garden, 73:325-347. 
WANG, BLANCHARD, \& DILCHER: EOCENE PLANTS FROM TENNESSEE

TABLE 2. Taxa and morphotypes reported from other Claiborne Group localities. LK - Lamkin, KY (UF15815); BO Bovay, MS (UF15737); BD - Bolden, MS (UF15738); WV - Water Valley, MS (UF19309); BC - Buchanan; TN (UF15806); LW - Lawrence, TN (UF15816); ML - Miller, TN (UF15817); NL - New Lawrence, TN (UF15818); PY - Puryear, TN (UF15820); RO - Rancho, TN (UF15821); RB - Richies Black, TN (UF15828); WB - Wilbanks II, TN (UF18927). “*” indicates the presence of a taxon/morphotype in a locality.

\begin{tabular}{|c|c|c|c|c|c|c|c|c|c|c|c|c|c|c|}
\hline \multirow{2}{*}{ Taxa / morphotype } & \multirow{2}{*}{$\begin{array}{l}\text { Proposed Modern } \\
\text { Affinity (Family) }\end{array}$} & \multirow{2}{*}{ Reference } & \multicolumn{12}{|c|}{ Localities } \\
\hline & & & LK & BO & BD & WV & BC & LW & ML & NL & PY & RO & RN & WB \\
\hline $\begin{array}{l}\text { Crepetocarpon } \\
\text { perkinsii }\end{array}$ & Euphorbiaceae & Dilcher and Manchester, 1988 & & & & & & * & * & * & & & * & \\
\hline $\begin{array}{l}\text { Castaneoidea } \\
\text { puryearensis }\end{array}$ & Fagaceae & Crepet and Daghlian, 1980 & & & & & & & & & * & & & \\
\hline $\begin{array}{l}\text { Eoengelhardia } \\
\text { puryearensis }\end{array}$ & Juglandaceae & Crepet et al., 1980 & & & & & & & & & * & & & \\
\hline $\begin{array}{l}\text { Paraoreomunnea } \\
\text { puryearensis }\end{array}$ & & $\begin{array}{l}\text { Dilcher, Potter and Crepet, } \\
1976\end{array}$ & * & & & & & & & & * & & & \\
\hline Eoceltis dilcheri & Ulmaceae & Zavada and Crepet, 1981 & & & & & & * & & & * & & & \\
\hline cf. Acrocarpus sp. & Leguminosae & Herendeen, 1992 & & * & & & & & & & & & & \\
\hline $\begin{array}{l}\text { cf. Caesalpinia L. } \\
\text { subg. Caesalpinia sp. }\end{array}$ & & & & & & & & * & & & * & & & \\
\hline Senna sp. & & & & & & & & & & & & * & & \\
\hline Crudia sp. & & & & & & & & & & * & & & & \\
\hline cf. Stemonocoleus sp. & & & * & & & & & & & & & & & \\
\hline cf. Cladrastis sp. & & & * & & & & & & & & * & & & \\
\hline Sophora L. & & & & & & & & & * & & & & & \\
\hline Caesalpinioid (?) fruit & & & * & & & & & & & & & & & \\
\hline $\begin{array}{l}\text { "Fruits similar to the } \\
\text { Sophoreae" }\end{array}$ & & & & & & & * & & & & * & & & \\
\hline $\begin{array}{l}\text { "Short, broad winged } \\
\text { fruit" }\end{array}$ & & & & * & & & & & & & * & & & \\
\hline $\begin{array}{l}\text { cf. Leguminosites } \\
\text { ingafructoides }\end{array}$ & & & & & & & & & & & * & & & \\
\hline Gordonia lamkinensis & Theaceae & Grote and Dilcher, 1992 & * & & & & & & & & & & & \\
\hline $\begin{array}{l}\text { Gordoniopsis } \\
\text { polysperma }\end{array}$ & & & & & & & & * & & & & & & \\
\hline $\begin{array}{l}\text { Croomiocarpon } \\
\text { mississippiensis }\end{array}$ & Icacinaceae & Stull et al., 2011 & & & & * & & & & & & & & \\
\hline Natsiatum wilxociana & & & & & & & & & & & & & & * \\
\hline $\begin{array}{l}\text { Phytocrene } \\
\text { densipunctata }\end{array}$ & & & & & & & & & & & & & & * \\
\hline $\begin{array}{l}\text { Magnolia } \\
\text { kentuckyensis }\end{array}$ & Magnoliaceae & Grote, 1989 & * & & & & & & & & & & & \\
\hline Magnolia tiffneyi & & & * & & & & & & & & & & & \\
\hline
\end{tabular}


Boucher, L.D., Manchester, S.R., and Judd, W.S. 2003. An extinct genus of Salicaceae based upon twigs with attached flowers, fruits, and foliage from the Eocene Green River Formation of Utah and Colorado, USA. American Journal of Botany, 90:13891399.

Bowerbank, J.S. 1840. A History of the Fossil Fruits and Seeds of the London Clay. van Voorst, London.

Brongniart, A. 1822. Sur la classification et la distribution des végétaux fossils en général, et sur ceux des terrains de sediment supérieur en particulier. Mémoires Museum National d'Histoire Naturelle, Paris, 8:297348.

Brown, R. 1818. Appendix B. pp. 374-379. In C. Abel. Narrative of a journey in the interior of China. Longman, London.

Brown, R.W. 1939. Fossil leaves, fruits, and seeds of Cercidiphyllum. Journal of Paleontology, 13:485499.

Brown, R.W. 1940. New species and changes of name in some American fossil flora. Journal of the Washington Academy of Sciences, 30:344-356.

Brown, R.W. 1944. Temperate species in the Eocene flora of the southeastern United States. Journal of the Washington Academy of Sciences, 34:349-351.

Brown, R.W. 1946. Alterations in some fossil and living floras. Journal of the Washington Academy of Sciences, 36:344-355.

Brown, R.W. 1960. Corkwood in the Eocene of the southeastern United States. Journal of Paleontology, 34:429-432.

Call, V.B. and Dilcher, D.L. 1992. Investigations of angiosperms from the Eocene of southeastern North America: samaras of Fraxinus wilcoxiana Berry. Review of Palaeobotany and Palynology, 74:249266.

Calvillo-Canadell, L. and Cevallos-Ferriz, S.R.S. 2007. Reproductive structures of Rhamnaceae from the Cerro del Pueblo (Late Cretaceous, Coahuila) and Coatzingo (Oligocene, Puebla) Formations, Mexico. American Journal of Botany, 94:1658-1669.

Chandler, M.E.J. 1961. The Lower Tertiary floras of southern England. I. Palaeocene floras. London Clay flora (supplement). British Museum (Natural History), London.

Corner, E.J.H. 1949. The annonaceous seed and its four integuments. New Phytologist, 48:332-364.

Crepet, W.L. 1978. Investigations of Angiosperms from the Eocene of North America: an aroid inflorescence. Review of Palaeobotany and Palynology, 25:241252.

Crepet, W.L. 1979. Some aspects of the pollination biology of middle Eocene angiosperms. Review of Palaeobotany and Palynology, 27:213-238.

Crepet, W.L. and Daghlian, C.P. 1980. Castaneoid inflorescences from the middle Eocene of Tennessee and the diagnostic value of pollen (at the subfamily level) in the Fagaceae. American Journal of Botany, 67:739-757.
Crepet, W.L. and Daghlian, C.P. 1982. Euphorbioid inflorescences from the middle Eocene Claiborne Formation. American Journal of Botany, 69:258-266.

Crepet, W.L. and Dilcher, D.L. 1977. Investigations of angiosperms from the Eocene of North America: a mimosoid inflorescence. American Journal of Botany, 64:714-725.

Crepet, W.L. and Taylor, D.W. 1986. Primitive mimosoid flowers from the Paleocene-Eocene and their systematic and evolutionary implications. American Journal of Botany, 73:548-563.

Crepet, W.L., Dilcher, D.L., and Potter, F.W. 1974. Eocene angiosperm flowers. Science, 185:781-782.

Crepet, W.L., Dilcher, D.L., and Potter, F.W. 1975. Investigations of angiosperms from the Eocene of southeastern North America: a catkin with Juglandaceous affinities. American Journal of Botany, 62:813-823.

Crepet, W.L., Nixon, K.C., and Zavada, M. 1980. Investigations of Angiosperms from the Eocene of North America: a new juglandaceous catkin. Review of Palaeobotany and Palynology, 30:361-370.

Crepet, W.L., Nixon, K.C., Friis, E.M., and Freudenstein, J.V. 1992. Oldest fossil flowers of hamamelidaceous affinity from the Late Cretaceous of New Jersey. Proceedings of National Academy of Sciences, USA, 89:8986-8989.

Daghlian, C.P. and Crepet, W.L. 1983. Oak catkins, leaves and fruits from the Oligocene Catahoula Formation and their evolutionary significance. American Journal of Botany, 70:639-649.

Daghlian, C.P., Crepet, W.L., and Delevoryas, T. 1980. Investigations of Tertiary angiosperms: a new flora including Eomimosoidea plumosa from the Oligocene of eastern Texas. American Journal of Botany, 67:309-320.

Danehy, D.R., Wilf, P., and Little, S.A. 2007. Early Eocene macroflora from the Red Hot Truck Stop Locality (Meridian, Mississippi, USA). Palaeontologia Electronica, 10:1-31. palaeo-electronica.org/2007_3/132/index.html.

de Candolle, A.P. and Perleb, K.J. 1818. Versuch über die Arzneikräfte der Pflanze. Sauerländer, Aarau.

de Jussieu, A.L. 1789. Genera Plantarum, secundum ordines naturales disposita juxta methodum in Horto Regio Parisiensi exaratam. Herissant \& Barrois, Paris.

Dilcher, D.L. 1963. Cuticular analysis of Eocene leaves of Ocotea obtusifolia. American Journal of Botany, $50: 1-8$.

Dilcher, D.L. 1969. Podocarpus from the Eocene of North America. Science, 164:299-301.

Dilcher, D.L. 1971. A revision of the Eocene floras of southeastern North America. Paleobotanist, 20:7-18.

Dilcher, D.L. 2000. Geological history of the vegetation in southeast United States. Sida, Botanical Miscellany, 18:1-21. 
Dilcher, D.L. and Daghlian, C.P. 1977. Investigations of angiosperms from the Eocene of southeastern North America: Philodendron leaf remains. American Journal of Botany, 64:526-534.

Dilcher, D.L. and Dolph, G.E. 1970. Fossil leaves of Dendropanax from Eocene sediments of southeastern North America. American Journal of Botany, 57:153160.

Dilcher, D.L. and Lott, T.A. 2005. A middle Eocene fossil plant assemblage (Powers Clay Pit) from Western Tennessee. Bulletin of the Florida Museum of Natural History, 45:1-43.

Dilcher, D.L. and Manchester, S.R. 1986. Investigations of angiosperms from the Eocene of North America: leaves of the Engelhardieae (Juglandaceae). Botanical Gazette, 147:189-199.

Dilcher, D.L. and Manchester, S.R. 1988. Investigations of the angiosperms from the Eocene of North America: a fruit belonging to Euphorbiaceae. Tertiary Research, 9:45-68.

Dilcher, D.L. and McQuade, J.F. 1967. A morphological study of Nyssa endocarps from Eocene deposits in western Tennessee. Bulletin of the Torrey Botanical Club, 94:35-40.

Dilcher, D.L. and Mehrotra, B. 1969. A study of leaf compressions of Knightiophyllum from Eocene deposits of southeastern North America. American Journal of Botany, 56:936-943.

Dilcher, D.L., Potter, F.W., and Crepet, W.L. 1976. Investigations of angiosperms from the Eocene of North America: Juglandaceous winged fruits. American Journal of Botany, 63:532-544.

Dolph, G.E. 1975. A statistical analysis of Apocynophyllum mississippiensis. Palaeontograhica Abt. $B$, $151: 1-51$

Don, D. 1825. Prodromus Florae Nepalensis. J. Gale, London.

Dumortier, B.C.J. 1829. Analyse des familles des plantes, avec l'indication des principaux genres qui s'y rattachent. J. Casterman aîné?, Tournay.

Ellis, J. 1771. A copy of a letter from John Ellis to Dr. Linnaeus. Philosophical Transactions of the Royal Society of London 60: 518-523.

Elsik, W.C. 1974. Characteristic Eocene palynomorphs in the Gulf Coast, U.S.A. Palaeontographica Abt. B, 149:90-111.

Elsik, W.C. and Dilcher, D.L. 1974. Palynology and age of clays exposed in Lawrence Clay Pit, Henry County, Tennessee. Palaeontographica Abt. B, 146:65-87.

Endress, P.K. and Friis, E.M. 1991. Archamamelis, hamamelidalean flowers from the Upper Cretaceous of Sweden. Plant Systematics and Evolution, 175:101114.

Engelhardt, D.W. 1964. Plant microfossils from the Eocene Cockfield Formation, Hinds County, Mississippi. Mississippi Geologic Research Papers Bulletin, 104:65-95.
Eyde, R.H. and Barghoorn, E.S. 1963. Morphological and paleobotanical studies of the Nyssaceae, II: The fossil record. Journal of the Arnold Arboretum, 44:328-370.

Ferguson, D.K. 1989. A survey of the Liquidambaroideae (Hamamelidaceae) with a view to elucidating its fossil record. In Crane, P.R. and Blackmore, S. (eds.), Evolution, Systematics, and Fossil History of the Hamamelidae, vol. 1, Systematics Association Special Volume. Clarendon Press, Oxford, UK.

Frederiksen, N.O. 1980a. Sporomorphs from the Jackson Group (upper Eocene) and adjacent strata of Mississippi and western Alabama. USGS Professional Paper, 1084:1-75.

Frederiksen, N.O. 1980b. Mid-Tertiary climate of southeastern United States: the sporomorph evidence. Journal of Paleontology, 54:728-739.

Frederiksen, N.O. 1988. Sporomorph biostratigraphy, floral changes, and paleoclimatology, Eocene and earliest Oligocene of the eastern Gulf Coast. USGS Professional Paper, 1448:1-68.

Gray, J. 1960. Temperate pollen genera in the Eocene (Claiborne) flora, Alabama. Science, 132:808-810.

Grote, P.J. 1989. Selected fruits and seeds from the middle Eocene Claiborne formation of southeastern North America. Unpublished Ph.D. dissertation. Department of Biology, Indiana University, Bloomington, Indiana, USA.

Grote, P.J. and Dilcher, D.L. 1989. Investigations of angiosperms from the Eocene of North America: a new genus of Theaceae based on fruit and seed remains. Botanical Gazette, 150:190-206.

Grote, P.J. and Dilcher, D.L. 1992. Fruits and seeds of Tribe Gordoniae (Theaceae) from the Eocene of North America. American Journal of Botany, 79:744753.

Herendeen, P.S. 1992. The fossil history of the Leguminosae from the Eocene of Southeastern North America. In Herendeen, P.S and Dilcher D.L. (eds.), Advances in Legume Systematics: Part 4, The Fossil Record. Kew Royal Botanic Garden.

Herendeen, P.S. and Dilcher, D.L. 1990a. Fossil mimosoid legumes from the Eocene and Oligocene of southeastern North America. Review of Palaeobotany and Palynology, 62:339-361.

Herendeen, P.S. and Dilcher, D.L. 1990b. Diplotropis (Leguminosae, Papilionoideae) from the middle Eocene of southeastern North America. Systematic Botany, 15:526-533.

Herendeen, P.S. and Dilcher, D.L. 1990c. Reproductive and vegetative evidence for the occurrence of Crudia (Leguminosae, Caesalpinioideae) in the Eocene of southeastern North America. Botanical Gazette, 151:402-413.

Herendeen, P.S. and Dilcher, D.L. 1991. Caesalpinia subgenus Mezoneuron (Leguminosae, Caesalpinioideae) from the Tertiary of North America. American Journal of Botany, 78:1-12. 
Herendeen, P.S., Less, D.H., and Dilcher, D.L. 1990. Fossil Ceratophyllum (Ceratophyllaceae) from the Tertiary of North America. American Journal of Botany, 77:7-16.

Heřmanová, Z. and Kvaček, J. 2010. Late Cretaceous Palaeoaldrovanda, not seeds of a carnivorous plant, but eggs of an insect. Journal of the National Museum (Prague), Natural History Series, 179:105118.

Hoffmannsegg, J.C. and Link, J.H.F. 1809. Flore portugaise, 1. Amelang, Berlin.

Ickert-Bond, S.M., Pigg, K.B., and Wen, J. 2005. Comparative infructescence morphology in Liquidambar (Altingiaceae) and its evolutionary significance. American Journal of Botany, 92:1234-1255.

Ickert-Bond, S.M., Pigg, K.B., and Wen, J. 2007. Comparative infructescence morphology in Altingia (Altingiaceae) and discordance between morphological and molecular phylogenies. American Journal of Botany, 94:1094-1115.

Jackson, G. 1811. Account of Ormosia, a new Genus of Decandrous Plants belonging to the Natural Order of Leguminosae. Transactions of the Linnaean Society, London Botany, 10:360.

Jones, J.H. 1984. Leaf architectural and cuticular analysis of extant Fagaceae and 'fagaceous' leaves from the Paleogene of southeastern North America. Unpublished Ph.D. dissertation, Indiana University, Bloomington, Indiana, USA.

Jones, J.H. and Dilcher, D.L. 1980. Investigations of angiosperms from the Eocene of North America: Rhamnus marginatus (Rhamnaceae) reexamined. American Journal of Botany, 67:959-967.

Jones, J.H. and Dilcher, D.L. 1988. A study of the "Dryophyllum" leaf forms from the Paleogene of southeastern North America. Palaeontographica Abt. B, 208:53-80.

Jones, J.H., Manchester, S.R., and Dilcher, D.L. 1988. Dryophyllum Debey ex Saporta, Juglandaceous not Fagaceous. Review of Palaeobotany and Palynology, 56:205-211.

Knobloch, E. and Mai, D.H. 1984. Neue Gattungen nach Früchten und Samen aus dem Cenoman bis Maastricht (Kreide) von Mitteleuropa. Feddes Repertoriu, 95:3-41.

Knobloch, E. and Mai, D.H. 1986. Monographie der Früchte und Samen in der Kreide von Mitteleuropa. Rozpravy Ústredního ústavu geologickénho, Praha, 47:1-219.

Knobloch, E. and Mai, D.H. 1991. Evolution of Middle and Upper Cretaceous floras in Central and Western Europe. Geologisches Jahrbuch Reihe A, 134: 257270.

Kovach, W.L. and Dilcher, D.L. 1984. Dispersed cuticles from the Eocene of North America. Botanical Journal of the Linnaean Society, 88:63-104.

Lesquereux, L. 1859. On some fossil plants of recent formations. American Journal of Science $2^{\text {nd }}$ Series, 27:359-366.
Lesquereux, L. 1869. On species of fossil plants from the Tertiary of the state of Mississippi. Transactions of the American Philosophical Society New Series, 13:411-430.

Lindley, J. 1836. A natural system of botany: or a systematic view of the Organisation (second edition). Longman, Rees, Orme, Brown, Green, and Longman, London.

Lindley, J. 1846. The Vegetable Kingdom; or, the structure, classification and uses of plants, illustrated upon the natural system. Bradbury \& Evans, London.

Link, J.H.F. 1831. Handbuch zur Erkennung dei nutzbarsten und am häufigsten vorkommenden gewächse. Haude und Spenerschen, Berlin.

Linnaeus, C. 1753. Species Plantarum: Exhibentes plantas rite cognitas, ad genera relates, cum differentiis specificis, nominibus trivialibus, synonymis selectis, locis natalibus, secundum systems sexuale digestas. Tomus I [II], Impensis Laurentii Salvii, Holmiae, Stockholm.

Linnaeus, C. 1768. Systema naturæ per regna tria naturæ, secundum classes, ordines, genera, species, cum characteribus \& differentiis. Tomus III. pp. $1-236$

Magallon-Puebla, S., Herendeen, P.S., and Endress, P.K. 1996. Allonia decandra: floral remains of the tribe Hamamelideae (Hamamelidaceae) from Campanian strata of southeastern USA. Plant Systematics and Evolution, 202:177-198.

Mai, D.H. 2001. The middle and upper Miocene floras of the Meuro and Rauno sequences in the Lusatica region. Part II: Dicotyledones. Palaeoontographica, Abt. B, 257:35-174.

Mai, D.H. and Walther, H. 1985. Die obereozänen Floren des Weisselster-Beckens und seiner Randgebiete. Abhandlungen aus dem Staatlichen Museum fur Tierkunde in Dresden 33:1-260.

Manchester, S.R. 1986. Vegetative and reproductive morphology of an extinct plane tree (Platanaceae) from the Eocene of western North America. Botanical Gazette, 147: 200-226.

Manchester, S.R. 1987. The fossil history of the Juglandaceae. Missouri Botanical Garden Monograph, 21:1-137.

Manchester, S.R. and Dilcher, D.L. 1979. A euphorbiaceous fruit from the middle Eocene of Tennessee. Botanical Society of America Miscellaneous Series Publication, 157:34.

Manchester, S.R. and Hickey, L.J. 2007. Reproductive and vegetative organs of Browniea gen. n. (Nyssaceae) from the Paleocene of North America. International Journal of Plant Sciences, 167:897-908.

Manchester, S.R. and O'Leary, E.L. 2010. Phylogenetic distribution and identification of fin-winged fruits. Botanical Review, 76:1-82.

Manchester, S.R. and Pigg, K.B. 2008. The Eocene mystery flower of McAbee, British Columbia. Botany, 86:1035-1038. 
Manchester, S.R., Judd, W.S., and Handley, B. 2006. Foliage and fruits of early poplars (Salicaceae: Populus) from the Eocene of Utah, Colorado, and Wyoming. International Journal of Plant Sciences, 167:897-908.

Manchester, S.R., Chen, Z.D., Lu, A.M., and Uemura, K. 2009. Eastern Asian endemic seed plant genera and their paleogeographic history throughout the Northern Hemisphere. Journal of Systematics and Evolution, 47:1-42.

Martinez-Millan, M. 2010a. Early fossil record of the Asteridae: revision, identification, phylogenetics and timing. Unpublished Ph.D. dissertation. Department of Plant Biology, Cornell University, Ithaca, New York, USA.

Martinez-Millan, M. 2010b. Fossil record and age of the Asteridae. Botanical Review, 76:83-135.

McNeill, J., Barrie, F.R., Buck, W.R., Demoulin, V., Greuter, W., Hawksworth, D.L., Herendeen, P.S., Knapp, S., Marhold, K., Prado, J., Prud'homme van Reine, W.F., Smith, G.E., Wiersema, J.H., Turland, N.J. (eds.) 2012. International Code of Nomenclature for algae, fungi, and plants (Melbourne Code) adopted by the Eighteenth International Botanical Congress Melbourne, Australia, July 2011. [Regnum Vegetabile no. 154.] A.R.G. Gantner Verlag, Ruggell.

Mindell, R.A., Stockey, R.A., and Beard, G. 2007. Cascadiacarpa spinosa gen. et sp. nov. (Fagaceae): castaneoid fruits from the Eocene of Vancouver Island, Canada. American Journal of Botany, 94:351-361.

Moore, B.R. 2001. Fossil plants from the Wilbanks Clay Pit (middle Eocene Claiborne Formation, Western Tennessee) paleontological implications and educational applications. Unpublished M.S. thesis. Department of Educational Studies, University of Tennessee, Martin, Tennessee, USA.

Moore, B.R., Dilcher, D.L., and Gibson, M.A. 2003. Paleoenvironment, depositional setting, and plant fossil diversity found in the Claiborne Formation (middle Eocene) clay deposits of western Tennessee. In Cox, R.T. (ed.), Field Trip Guidebook, Joint Meeting South-Central and Southeastern Sections of Geological Society of America. State of Tennessee, Department of Environment and Conservation, Division of Geology, Report of Investigations, 51:187-198.

O'Leary, E.L. 2007. Taxonomic distribution of modern finwinged fruits and the fossil history of the Combretaceae in the United States based on fin-winged fruits. Unpublished M.S. thesis. Department of Botany, University of Florida, Gainesville, Florida, USA.

Owen, D.D. 1860. Second Report of Geological Reconnoissance of the Middle and Southern Counties of Arkansas. C. Sherman \& Son, Philadelphia.

Parameswaran, N. 1961. Ruminate endosperm in Canellaceae. Current Science, 30:344-345.

Parks, W.S. and Carmichael, J.K. 1990. Geology and ground-water resources of the Cockfield Formation in western Tennessee. U.S. Geological Survey WaterResources Investigations Report, 88-4181:1-17.
Perkins, G.H. 1904. Report of the State Geologist on the mineral industries and geology of certain areas of Vermont. 1903-1904. Fourth of the Series. Argus and Patriot Printing House, Montpelier, VT.

Pigg K.B. and Wehr W.C. 2002. Tertiary flowers, fruits and seeds of Washington State and adjacent areas, part III. Washington Geology, 30:3-20.

Potter, F.W., Jr. 1976. Investigations of angiosperms from the Eocene of southeastern North America: Pollen assemblages from Miller pit, Henry County, Tennessee. Palaeontographica Abt. B, 157:44-96.

Potter, F.W., Jr. and Dilcher, D.L. 1980. Biostratigraphy analysis of Eocene clay deposits in Henry County, Tennessee. In Dilcher, D.L. and Taylor, T.N. (eds.), Biostratigraphy of Fossil Plants. Dowden, Hutchinson \& Ross, Inc., Stroudsburg.

Reid, E.M., and Chandler, M.E.J. 1933. The Flora of the London Clay. British Museum (Natural History), London.

Roth, J.L. 1981. Epidermal studies in the Annonaceae and related families. Unpublished Ph.D. dissertation. Department of Biology, Indiana University, Bloomington, Indiana, USA.

Roth, J.L. and Dilcher, D.L. 1979. Investigations of angiosperms from the Eocene of North America: stipulate leaves of the Rubiaceae including a probable polyploid population. American Journal of Botany, 66:1194-1207.

Safford, J.M. 1869. Geology of Tennessee. S.C. Mercer, Nashville, Tennessee.

Sanjappa, M. 1994. Crudia (Leguminosae: Caesalpinioideae), a new generic record for India with a new species of the genus. Key Bulletin, 49:565-568.

Saporta, G. DE. 1862. Études sur la vegétation du sudest de la France à l'époque tertiaire, Vol. 1, pt. 2. Annales des sciences naturelle., ser. 4, Botanique, 17:191-311.

Siebold, P. and Zuccarini, C. 1836. Flora Japonica. Lugduni Batavorum, Leiden.

Stull, G.W., Moore, B.R., and Manchester, S.R. 2011. Fruits of Icacinaceae from the Eocene of southeastern North America and their biogeographic implications. International Journal of Plant Sciences, 172:935-947.

Stull, G.W., Herrera, F., Manchester, S.R., Jaramillo, C.A., and Tiffney, B.H. 2012. Fruits of an "Old World" tribe (Phytocreneae; Icacinaceae) from the Paleogene of North and South America. Systematic Botany, 37:784-794.

Sun, Z. 1989. General geology and floristic survey of the Warman clay pit, Weakley County, Tennessee. Unpublished M.S. thesis. Department of Geology, Indiana University, Bloomington, Indiana, USA.

Taylor, D.W. 1987. Survey of biogeographic relations of North American angiosperms from the Upper Cretaceous and Paleogene. Unpublished Ph.D. dissertation. University of Connecticut, Storrs, Connecticut, USA. 
Taylor, D.W. 1988. Eocene floral evidence of Lauraceae: corroboration of the North American megafossil record. American Journal of Botany, 75:948-957.

Taylor, D.W. 1989. Select palynomorphs from the middle Eocene Claiborne Formation, Tennesee, (USA). Review of Palaeobotany and Palynology, 58:111128.

Taylor, D.W. and Crepet, W.L. 1987. Fossil floral evidence of Malpighiaceae and an early plant-pollinator relationship. American Journal of Botany, 74:274286.

Tiffney, B.H. 1977. Fruits and seeds of the Brandon Lignite: Magnoliaceae. Botanical Journal of the Linnaean Society, 75:299-323.

Tiffney, B.H. 1986. Fruit and seed dispersal and the evolution of the Hamamelidae. Annals of the Missouri Botanical Garden, 73:394-416.

Tschudy, R.H. 1973. Stratigraphic distribution of significant Eocene palynomorphs of the Mississippi Embayment. USGS Professional Paper, 743-B:1-24.

van Setten, A.K. and Koek-Noorman, J. 1992. Fruits and seeds of Annonaceae: morphology and its significance for identification. Bibliotheca Botanica, 142:1101. von Schreber, J.C.D. 1789. In Linnaeus, C., Genera Plantarum (8 ed.), 1:282. Varrentrappii et Wenner, Frankfurt.

von Schreber, J.C.D. 1791. Genera Plantarum (8 ed.), p.G74. Varrentrappii et Wenner, Frankfurt.

Watson, L. and Dallwitz, M.J. 1992 onwards. The families of flowering plants: descriptions, illustrations, identification, and information retrieval. Version: 25th November 2009. delta-intkey.com.

Wehr, W.C. and Hopkins, D.Q. 1994. The Eocene orchards and gardens of Republic, Washington. Washington Geology, 22:27-34.

Weiss, J. 1980. Fossil mimosoid leaflets from the middle Eocene (Claiborne Formation), Graves County, Kentucky. Unpublished M.S. thesis. Department of Geology, Indiana University, Bloomington, Indiana, USA.

Zavada, M.S. and Crepet, W.L. 1981. Investigations of Angiosperms from the middle Eocene of North America: flowers of the Celtidoideae. American Journal of Botany, 68:924-933.

Zhou, Z., Crepet, W.L., and Nixon, K.C. 2001. The earliest fossil evidence of the Hamamelidaceae: Late Cretaceous (Turonian) inflorescences and fruits of Altingioideae. American Journal of Botany, 88:753766. 